\title{
WAS THE FIRST PUBLIC HEALTH CAMPAIGN SUCCESSFUL? THE TUBERCULOSIS MOVEMENT AND ITS EFFECT ON MORTALITY
}

\author{
D. Mark Anderson \\ Kerwin Kofi Charles \\ Claudio Las Heras Olivares \\ Daniel I. Rees \\ Working Paper 23219 \\ http://www.nber.org/papers/w23219
NATIONAL BUREAU OF ECONOMIC RESEARCH
1050 Massachusetts Avenue
Cambridge, MA 02138
March 2017

\begin{abstract}
The views expressed herein are those of the authors and do not necessarily reflect the views of the National Bureau of Economic Research. Partial support for this research came from a Eunice Kennedy Shriver National Institute of Child Health and Human Development research infrastructure grant, R24 HD042828, to the Center for Studies in Demography and Ecology at the University of Washington.
\end{abstract}

NBER working papers are circulated for discussion and comment purposes. They have not been peer-reviewed or been subject to the review by the NBER Board of Directors that accompanies official NBER publications.

(C) 2017 by D. Mark Anderson, Kerwin Kofi Charles, Claudio Las Heras Olivares, and Daniel I. Rees. All rights reserved. Short sections of text, not to exceed two paragraphs, may be quoted without explicit permission provided that full credit, including $\$ notice, is given to the source. 
Was The First Public Health Campaign Successful? The Tuberculosis Movement and Its Effect on Mortality

D. Mark Anderson, Kerwin Kofi Charles, Claudio Las Heras Olivares, and Daniel I. Rees

NBER Working Paper No. 23219

March 2017

JEL No. I1

\section{$\underline{\text { ABSTRACT }}$}

The U.S. tuberculosis movement pioneered many of the strategies of modern public health campaigns. Dedicated to eradicating a specific disease, it was spearheaded by voluntary associations and supported by the sale of Christmas seals. Although remarkable in its scope and intensity, the effectiveness of the tuberculosis (TB) movement has not been studied in a systematic fashion. Using newly digitized mortality data at the municipal level for the period 1900-1917, we explore the effectiveness of the measures championed by the TB movement. Our results suggest that the adoption of a municipal reporting requirement was associated with a 6 percent decrease in pulmonary TB mortality, while the opening of a state-run sanatorium was associated with an almost 4 percent decrease in pulmonary TB mortality. However, these and other anti-TB measures can explain, at most, only a small portion of the overall decline in pulmonary TB mortality observed during the period under study.

D. Mark Anderson

Department of Agricultural Economics

and Economics

Montana State University

Bozeman, MT 59717-2920

\& Institute of Labor Economics (IZA)

dwight.anderson@montana.edu

Kerwin Kofi Charles

Harris School of Public Policy

University of Chicago

1155 East 60th Street

Chicago, IL 60637

and NBER

kcharles@uchicago.edu
Claudio Las Heras Olivares

Banco de Chile

claudiolho@gmail.com

Daniel I. Rees

University of Colorado Denver

Department of Economics

Campus Box 181

P.O. Box 173364

Denver, CO 80217-3364

\& Institute of Labor Economics (IZA)

Daniel.Rees@ucdenver.edu 


\section{INTRODUCTION}

In 1900, 194 out of every 100,000 Americans died of tuberculosis (TB), making it the second-leading cause of death, behind only pneumonia/ influenza (Jones et al. 2012). Although an effective treatment would not be introduced until after World War II (D aniel 2006), the TB mortality rate fell dramatically over the next three decades. By 1920, it had fallen to 113 per 100,000 persons; by 1930, it had fallen to 71 per 100,000 persons (Jones et al. 2012).

How was TB vanquished, or at least controlled, in the United States and other developed countries? Scholars have proposed several explanations, including better living conditions, herd immunity due to natural selection, reduced virulence, and improved nutrition (Smith 2003; D aniel 2006; Kunitz 2007, pp. 196-197; Lönnroth et al. 2009; Mercer 2014, pp. 127-129). The introduction of basic public health measures (e.g., isolating patients in sanatoriums and TB hospitals) is another potential explanation (Wilson 1990; Fairchild and O ppenheimer 1998), but scholars have questioned whether such measures contributed meaningfully to the decline in TB mortality (McKeown 1976; Coker 2003; D aniel 2006). ${ }^{1}$

D rawing on newly digitized data from a variety of primary sources, the current study explores whether the TB movement contributed to the decline in TB mortality in the United States. The movement began with the establishment of the Pennsylvania Society for the Prevention of Tuberculosis in 1892 and gained momentum when the National Association for the Study and Prevention of Tuberculosis (NASPT) was founded in 1904 (Shryock 1957, p. 52; Teller 1988, p. 30). Spearheaded by voluntary associations composed of both laypersons and physicians and supported

\footnotetext{
${ }^{1}$ See also Tomes (1989), Bates (1989; 1992), Vynnycky and Fine (1999), and Wilson (2005). Bates (1989, p. 349) wrote that, "in the absence of controlled studies", we may never know "whether or to what degree the tuberculosis movement contributed to the declining death rate in the United States or improved the health of tuberculosis patients." Tomes (1989, p. 477), although also skeptical, argued that "[h]istorians may fairly question the wisdom of spending money on sanatoria instead of on housing subsidies, but they cannot conclusively prove that the tuberculosis movement as a whole played no role in the 'retreat' of the disease."
} 
by the sale of Christmas seals, the U.S. TB movement pioneered many of the strategies of modern public health campaigns (Teller 1988 p. 1 and pp. 121-126; Jones and Greene 2013; Rosen 2015, pp. 226-231).

Between 1900 and 1917, hundreds of state and local TB associations sprung up across the United States (NASPT 1916; Knopf 1922). These associations distributed educational materials and provided financial support to sanatoriums and TB hospitals, where patients with active TB were isolated from the general population and, if lucky, could recover. In addition, these associations advocated, often successfully, for the passage of legislation designed to curb the transmission of TB, including requirements that doctors notify local public health officials about active TB cases.

Reporting requirements were a key feature of the campaign against TB (Knopf 1922, p. 149; Teller 1988, p. 22; Rothman 1995, p. 187). These requirements prevented physicians from concealing a diagnosis of TB from their patients and allowed local health officials to monitor TB patients, ensuring that they were taking precautions not to infect others (Teller 1988, p. 22). In several states, "careless consumptives" could be forcibly committed to TB hospitals or sanatoriums, where they were not a threat to the health of their family and co-workers (Teller 1988, pp. 93-94; Roberts 2009, p. 186). When a TB patient died, municipalities and states often required that his or her premises be thoroughly disinfected.

Although remarkable in its scope and intensity, the effectiveness of the U.S. TB movement has, to date, not been studied in a systematic fashion. ${ }^{2}$ Using municipal-level data for the period

2 Two recent working papers by economists have examined the effects of specific anti-TB public health measures undertaken before an effective treatment for TB was available. Hollingsworth (2014) estimated the relationship between sanatoriums and pulmonary TB mortality using data from North Carolina for the period 1932-1940. He found that an additional sanatorium bed reduced the pulmonary TB mortality rate among whites by .695 per 100,000 population, but had no effect on the black TB mortality rate. Hansen et al. (2017) estimated the relationship between TB dispensaries and TB mortality at the municipal level using data from Denmark for the period 1890-1939. These authors found that the opening of a TB dispensary was associated with a 16 percent reduction in the TB mortality rate, an effect they attributed to dispensaries "facilitating a local diffusion of (hygiene) knowledge about the disease." Hansen et al. (2017) also found that the opening of a sanatorium was associated with a (statistically insignificant) increase in the local TB mortality rate, but noted that, because Denmark is not a large country, TB patients "had the liberty of choosing the 
1900-1917 from Matality Statistics which was published on an annual basis by the U.S. Census Bureau, we estimate the relationship between pulmonary TB mortality and the introduction of public health measures designed to curb the spread of the disease. Such measures included the establishment of sanatoriums, TB hospitals and open-air camps, prohibitions on spitting and the use of common drinking cups, requirements that local health officials be notified about TB cases, and requirements that the premises of deceased TB patients be disinfected.

O ur estimates, which control flexibly for common shocks and municipal-level heterogeneity, suggest that most anti-TB measures had no discernable impact on pulmonary TB mortality. Two exceptions to this general result stand out: requiring TB cases to be reported to local health officials is associated with a 6 percent reduction in pulmonary TB mortality, and the opening of a state-run sanatorium is associated with an almost 4 percent reduction in pulmonary TB mortality. These estimated effects are robust across a variety of specifications, but can explain, at most, only a small portion of the overall decline in pulmonary TB mortality observed during the period 1900-1917.

\section{BACKGROUND}

Today, cancer and coronary health disease are the leading causes of death in the United States (National Center for Health Statistics 2016), but, at the turn of the $20^{\text {th }}$ century, most Americans did not expect to die from these so-called "modern diseases": influenza, pneumonia, tuberculosis, and gastrointestinal infections took a far greater toll (Jones et al. 2012). The United States experienced a rapid decline in mortality from infectious diseases during the early 1900s Jones et al. 2012). By 1930, coronary heart disease had become the leading cause of death (Jones et al.

sanatorium across the country that they liked the most." By contrast, all but the wealthiest TB patients in the United States would have viewed out-of-state sanatoriums as too expensive (Rothman (1995, pp. 207-210). In the United States, state-run and local sanatoriums represented a substantial portion of total capacity (Teller 1988, p. 82), making it much easier to identify their effects on TB mortality. 
2012); by 1948, Secretary of State G eorge Marshall declared with confidence that the conquest of all infectious diseases was imminent (Garrett 1994, p. 30).

In an oft-cited review, Cutler et al. (2006) attributed the unprecedented decline in infectious disease mortality experienced in the United States and other Western countries to basic public health measures, including the building of sewage systems, the delivery of clean water, and educational campaigns designed to promote better hygiene. The evidence that sewers and clean water contributed to declines in mortality from diarrhea, dysentery, enteritis, typhoid, and other waterborne diseases is quite strong (Troesken 2001; Cutler and Miller 2005; Ferrie and Troesken 2008; Alsan and Goldin 2015; Beach et al. 2016). ${ }^{3}$ However, several prominent scholars have suggested that public health measures did not contribute meaningfully to the decline in TB mortality (McKeown 1976; Coker 2003; D aniel 2006), nor is there particularly convincing evidence that public health measures contributed to the decline in mortality from other important airborne diseases such as influenza, scarlet fever, and whooping cough (Condran and Crimmins-G ardner 1978; Condran and Cheney 1982; Swedlund and D onta 2002; Bootsma and Ferguson 2007).

Gaining a better understanding of the factors that contributed to the control of infectious diseases in the United States could help in the design and implementation of public health interventions in the developing world, where TB remains widespread (World Health O rganization 2015; Houben and D odds 2016). Although most TB infections can be successfully treated with antimicrobial drugs, the World Health Organization estimates that 3.3 percent of new TB cases are multidrug-resistant (WHO 2015, p. 4). The recommended treatment for drug-susceptible TB lasts 6 months, but treatment for multidrug-resistant TB takes 20 months, requires more toxic drugs, and

\footnotetext{
3 Relatedly, Clay et al. (2014) found that waterborne lead exposure was associated with higher rates of infant mortality at the turn of the $20^{\text {th }}$ century.
} 
has a much lower success rate (Lange et al. 2014; WHO 2015, p. 56). ${ }^{4}$ With multidrug-resistant TB infections on the rise (Lange et al. 2014), some experts have suggested that it may be "time to bring back sanatoria" (D heda and Migliori 2012, p. 773). At a minimum, assessing the effectiveness of basic public health measures, many of which were pioneered by the U.S. TB movement, has taken on a new urgency.

\subsection{A brief introduction to tuberculosis}

TB can affect bones, the central nervous system, and other organ systems, but it is primarily a pulmonary disease. In 1882, Robert Koch demonstrated that TB is caused by Mycobaderium tuberailosis which can be spread through coughing, sneezing, or spitting, although many turn-of-thecentury doctors in the United States still believed that TB was inherited (Teller 1988, p. 23). ${ }^{5}$ D uring the period under study, TB was often referred to as "consumption" and its sufferers were referred to as "consumptives" (Bynum 2012), reflecting the gradual weight loss caused by the disease.

Over 90 percent of TB infections are latent-asymptomatic and non-communicable (Lawn and Zumla 2011, p. 61). However, approximately half of individuals with active pulmonary TB eventually die if they do not receive treatment (Rutledge and Crouch 1919; Thompson 1943; Gideon and Flynn 2011). ${ }^{6}$ Symptoms include a chronic cough, fevers, night sweats, and weight loss (Lawn and Zumla 2011, p. 65).

\footnotetext{
4 Multidrug-resistant TB is caused by the bacteria adapting to isoniazid and rifampicin, the two most potent anti-TB drugs, making them ineffective (Lange et al. 2014).

5 See Lawn and Zumla (2011) for more about the history and microbiology of Mycdbacteiumtubeaulosis

${ }^{6}$ For instance, Thompson (1943) examined 406 TB patients diagnosed between 1928 and 1938. One year after their diagnosis, 40 percent had died; two years after diagnosis, almost 60 percent had died. In a review of studies from the pre-chemotherapy era, Tiemersma et al. (2011) concluded that the duration of TB from onset to either cure or death was, on average, 3 years.
} 
At the turn of the $20^{\text {th }}$ century, TB was the second-leading cause of death in the United States (Jones et al. 2012). ${ }^{7}$ It was greatly feared, in part because it often affected healthy men and women in the prime of life (D onald 2016; Tomes 2000). Incident rates were highest in the rapidly growing urban areas of the United States, where people lived and worked in close proximity to one another. In rural areas of the United States, the TB mortality rate was roughly half that of large cities such as Boston, New Orleans, New York, San Francisco, and Washington D .C. ${ }^{8}$ An effective treatment would not be introduced until after World War II (D aniel 2006), yet the TB mortality rate fell by more than 60 percent from 1900 to 1930 (Jones et al. 2012). ${ }^{9}$ Many, if not most, contemporary observers credited the TB movement for this dramatic reduction in TB mortality (Emerson 1922; Bates 1992, pp. 317-318).

\section{The Tuberculosis Movement}

The TB movement was, in many respects, the first modern public health campaign. D edicated to eradicating a specific disease, it was spearheaded by voluntary groups, involved laypersons as well as medical professionals, and, beginning in 1908, was almost entirely funded by the sale of Christmas seals (Knopf 1922, pp. 55-66; Shryock 1957, pp. 55-57; Rosen 2015, pp. 226-

\footnotetext{
7 TB has a long and reasonably well documented history. Lesions and other tubercular deformities have been found on the mummified remains of ancient Egyptians, and classical $\mathrm{G}$ reek and Roman doctors recognized its symptoms (D aniel 2000, p. 29; Daniel 2006, p. 1863; Smith 2003, p. 465). In Homer's Odyssg, the poet referenced a "grievous consumption", which took the soul from one's body (Bynum 2012, p. 13). TB mortality rates in Europe soared with the growth of urban centers such as London and Paris, and peaked in the first half of the 19th century (D ubos and Dubos 1952, p. 9 and pp. 185-186; Smith 2003, p. 465).

8 See the U.S. Bureau of the Census (1908, p. 66) for TB mortality rates in cities with a population of greater than 100,000 and in the rural areas of registration states.

9 The first vaccine, BCG, was introduced in 1921 (Lawn and Zumla 2011, p. 67). Although vaccination campaigns were undertaken in Europe, no such campaign was launched in the United States (Cutler et al. 2006, p. 103). Today, despite widespread use of the BCG vaccine, TB is still one of the leading causes of mortality in developing nations, with 1.5 million people succumbing to it every year (World Health O rganization 2015). It is estimated that approximately onefourth of the world's population has a latent TB infection (Houben and D odd 2016).
} 
231). ${ }^{10}$ By harnessing the enthusiasm of laypersons, and coupling this enthusiasm with the knowledge and guidance of professionals, the TB movement inspired and directly shaped subsequent public health campaigns in the United States and around the world (Jacobs 1921; Shryock 1957, pp. 55-56 and pp. 179-182; Rosen 2015, pp. 226-231).

Between 1900 and 1917, hundreds of state and local TB associations were established across the United States (NASPT 1911, 1916, 1919). By 1917, the last year for which we have data, the NASPT was raising well over a million dollars per year through the sale of Christmas seals, and every state had its own association (Knopf 1922). TB associations sponsored lectures, mounted exhibits, distributed press releases, and gave out circulars emphasizing the importance of germ awareness and proper hygiene (Teller 1988, pp. 59-61). Men were urged to shave their beards and carry pocket spittoons, women were urged to stop wearing trailing dresses, and children were taught to play outdoors, keep their face, hands, and fingernails clean, and cover their coughs and sneezes. ${ }^{11}$

The goals and aspirations of TB associations went well beyond educating the public. TB associations provided financial support to sanatoriums, TB hospitals, open-air camps, and dispensaries. They also advocated for the passage of legislation designed to curb the spread of TB and worked closely with local and state health officials, who adopted and distributed their

\footnotetext{
${ }^{10}$ Even today, the American Lung Association's mission is largely funded by the sale of Christmas seals (see www.christmasseals.org).
}

11 For a historical perspective on the hygiene practices promoted by tuberculosis associations see Tomes (1998, pp. 113134) and Tomes (2000). An exhaustive list of contemporary hygiene-related admonitions is provided by Knopf (1901). For instance, Knopf (1901, pp. 21-22) wrote:

In factories, stores, railway cars, waiting-rooms... , menageries- in short wherever many people congregate - there should be a sufficient number of cuspidors well kept and regularly cleaned. They should be made of unbreakable material and have wide openings. If such measures are carried out, there will be no excuse for any one to expectorate on the floor and thus endanger the lives of his fellow-men.

Knopf (1901) also urged children "to always play outdoors unless the weather is too stormy" (p. 72), and advised them to "learn to love fresh air", not to "kiss any one on the mouth", and not to "put pencils in your mouth or wet them with your lips" (p. 71). 
educational materials. ${ }^{12}$ Below, we describe the history and functions of sanatoriums, TB hospitals, open-air camps, and dispensaries. After describing these institutions, we briefly summarize the antiTB legislation passed during the period under study. ${ }^{13}$

\subsection{Sanatoniums}

The first sanatoriums in the United States were established at the end of the $19^{\text {th }}$ century (Knopf 1922, p. 10). Typically located in rural areas or the mountains, they provided a place for TB patients to rest, breathe fresh air, and eat nutritious food. Although TB patients admitted to sanatoriums had similar recovery rates as compared to those who went untreated (Bignall 1977; Teller 1988, pp. 89-90; D aniel 2006), medical professionals at the turn of the $20^{\text {th }}$ century, including the leaders of the TB movement, were convinced that sanatoriums could cure pulmonary TB (Wethered 1906; Knopf 1908). In addition to offering the promise of a cure, sanatoriums isolated TB patients from the community at large and taught them how to avoid infecting their family, friends, and coworkers.

In 1900, there were only 34 sanatoriums operating in the United States, with a total capacity of roughly 4,500 beds (Rothman 1995, p. 198). After the NASPT began selling Christmas seals, additional funds became available and the number of sanatoriums grew rapidly. By 1917, there were well over 200 sanatoriums in operation with a total capacity of more than 19,000 beds (NASPT 1916; Teller 1988, p. 82). Some sanatoriums catered to the rich, offering excellent food and a spalike atmosphere (Bates 1992, p. 195; Rappold 2007). In contrast, conditions at publicly funded sanatoriums could be quite primitive with patients living in tents or lean-tos on the outskirts of

\footnotetext{
12 Teller (1988, p. 46) wrote that "cooperation between public health officials and the voluntary associations was very common", but noted that "some officials resented the interference of the tuberculosis associations or thought their enthusiasm was misplaced."

${ }^{13}$ Knopf (1922), Shryock (1957), and Teller (1988), among others, provide detailed histories of the TB movement.
} 
urban areas. Several publicly funded sanatoriums required patients to perform manual labor as a means of controlling costs. ${ }^{14}$

\subsection{TB hospitals}

By 1908, a number of prominent public health experts had come to the conclusion that sanatoriums were inadequate to the task at hand (Bloede 1908; Brown 1908; Newsholme 1908). TB patients were observed to recover when provided with nutritious food and an opportunity to rest, only to relapse upon discharge. More resources, they argued, should be devoted towards isolating the most infections patients- those with advanced pulmonary TB (Bloede 1908; Brown 1908; Newsholme 1908; Hutchinson 1911; Flick 1912). Although a handful of hospitals specialized in caring for these patients, beds were in short supply and conditions were generally abysmal (Waters 1912; Teller 1988, p. 92; Abel 2007, p. 42). Working together, local TB associations and municipal governments opened more facilities; by 1917, there were roughly 150 TB hospitals operating in the United States (NASPT 1916; Knopf 1922; Teller 1988, p. 92). ${ }^{15}$

\subsection{0 pen-air camps}

Open-air camps (also referred to as day camps), were seen as a low-cost alternative to sanatoriums for ambulatory TB patients (Robbins 1906; Townsand 1909). D uring the day, patients received care and were taught how to avoid infecting their family, friends, and coworkers. At night, they returned home "to practice the lessons learned" (Townsand 1909, p. 755). The first open-air camp in the United States was established by the Boston Association for the Relief and Control of

\footnotetext{
14 See Klebs (1909), Bignall (1977), Feldberg (1995, pp. 93-94), Rothman (1995, pp. 207-210), Abel (2007, p. 43), and Rappold (2007) for more details on the conditions in sanatoriums.

15 This count includes both hospitals specializing in the care of TB patients and general hospitals with wards set aside specifically for TB patients.
} 
Tuberculosis in 1905 (Robbins 1906). A decade later, more than 60 open-air camps were operating across the country (NASPT 1916).

\subsection{Dispensaries}

Dispensaries functioned as diagnostic units, disseminated educational materials to the public, and served as "clearing houses", sending patients to physicians, sanatoriums, or TB hospitals for treatment (Knopf 1911, p. 112; Bynum 2012). ${ }^{16}$ Dispensaries also provided medicines such as cod liver oil or opiate-based cough mixtures (Bynum 2012; Fraser and Clark 1912), which offered temporary relief but could not cure TB. The first TB dispensary in the United States was established in 1891 by Philadelphia's Rush Hospital for Consumption and Allied Diseases; by 1917, there were hundreds of dispensaries in operation across the country (NASPT 1919).

\subsection{Reporting requirements}

Tuberculosis associations advocated forcefully, and often successfully, for the passage of laws designed to prevent the spread of the disease. In particular, reporting requirements were viewed as crucial to the success of the anti-TB campaign (Knopf 1922, p. 149; Teller 1988, p. 22; Rothman 1995, p. 187). Today, TB case-notification policies and practices are well established in developed, Western countries, yet under-notification remains a problem in the developing world (Uplekar et al. forthcoming). ${ }^{17}$

At the turn of the $20^{\text {th }}$ century, it was common for physicians to conceal a TB diagnosis from their patients (Ambler 1903; Cabot 1908; G irdwood 1910). Physicians feared that their

\footnotetext{
${ }^{16}$ D ispensary staff made home visits to educate TB patients on disposing of their sputum, using separate utensils, and cleaning their home and laundry (Bynum 2012).

${ }^{17}$ The World Health O rganization's End TB Strategy specifically highlights mandatory TB case notification as integral to ending the TB epidemic by 2030 (Uplekar et al. forthcoming).
} 
patients, upon being told that they had an incurable disease, would seek a second opinion or remove themselves to a sanatorium (Fox 1975). By obligating physicians to notify local health officials of active TB cases, reporting requirements were designed to put an end to this practice and facilitate the monitoring and education of TB patients. D uring the period under study, 27 states and over 100 municipalities adopted reporting requirements (NASPT 1911, 1916). In New Jersey, New Y ork, Minnesota, Virginia, and Wisconsin, so-called "careless consumptives" could be forcibly committed to TB hospitals or sanatoriums (Teller 1988, pp. 93-94; Roberts 2009, p. 186).

\subsection{Disinfection laws}

Between 1900 and 1917, 15 states and over 150 municipalities adopted disinfection requirements (NASPT 1916). When a living space was left vacant by the death or removal of a TB patient, the attending physician was expected to notify public health officials so that it could be disinfected. Health officers directed the disinfection and, when deemed necessary, the renovation of the premises. ${ }^{18}$

\subsection{Spitting bans}

Chewing tobacco was popular at the turn of the twentieth century, and spittoons could be found in offices, hotels, and public buildings. D espite the availability of spittoons, contemporary accounts describe sidewalks and even the floors of street cars as covered in spittle ( ${ }^{\prime}$ Conner 2015). By 1917, there were over 150 municipal bans on spitting (NASPT 1916). There is anecdotal

\footnotetext{
18 Knopf (1901, pp. 22-23) provided step-by-step instructions on the "disinfection of the sick-room." See Vallejo,
} California (1913) and Colorado (1914) for examples of disinfection laws. 
evidence, however, that these bans were not particularly well enforced. D espite fines as high as $\$ 25$ dollars per infraction, very few people were actually arrested for spitting in public (Newton 1910). ${ }^{19}$

\subsection{Common drinking cup bans}

Common drinking cups, which were located in schools, trains, and next to municipal water pumps, were viewed as yet another important source of TB infection (Sedgwick 1902; Tomes 1998; Sattar 2016). By 1917, 17 states and more than 150 municipalities had banned the use of the common cup (NASPT 1911, 1916). Working with local governments, tuberculosis associations made drinking fountains available in schools and other public buildings, but common cups continued to be popular, especially in small towns and rural areas (Nydegger 1917; Boudreau 1920; Gladden 1921; McGuire 2012). ${ }^{20}$

\section{Mort ality Data and Empirical Framework}

Municipal-level mortality data come from Matality Statistics published annually by the U.S. Census Bureau. The inaugural issue of Matality Statisticswas published in 1900 and contained mortality counts by cause for over 300 municipalities. ${ }^{21}$ By 1917, mortality counts for over 500 municipalities were available. Although the Census Bureau continued to publish Martality Statistics

\footnotetext{
${ }^{19}$ Enforcement appears to have been stricter in New Y ork City where, according to Newton (1910), health officers had made 2,513 arrests for violations of the anti-spitting ordinance passed in 1896. Although anti-spitting laws are still on the books, enforcement appears to be extremely lax (York 2003; Williams 2015).

${ }^{20}$ Along with drinking fountains, dispensable cups (e.g., the Dixie Cup) eventually replaced the common cup entirely (Lee 2007).

${ }^{21}$ Cause of death was obtained from the death certificate and coded using the Intemational Classification ofDises When more than one medical condition was listed on the death certificate, cause of death was based on a standardized algorithm (Armstrong et al. 1999). There is evidence that deaths from TB were, with some frequency, attributed to bronchitis, malaria, and/ or pneumonia (Cabot 1900, p. 27; Cabot 1912), an issue we address below.
} 
through 1922, we chose to focus on the period 1900-1917 in an effort to avoid potential confounding from the effects of the 1918 influenza epidemic.

In Figure 1, we report the pulmonary TB mortality rate per 100,000 population for the 548 municipalities in our sample by year. ${ }^{22}$ The pulmonary TB mortality rate was 173 per 100,000 population in $1900 .{ }^{23}$ From 1900 to 1917, it fell by nearly 28 percent, to 125 . We begin our exploration of whether the anti-TB measures championed by the TB movement and described in the previous section contributed to this dramatic reduction in pulmonary TB mortality by estimating the following baseline regression:

$$
\ln (\text { PulmonaryTB Matality })=\beta_{0}+\mathbf{X}_{\mathrm{nt}} \beta_{1}+\mathrm{v}_{\mathrm{m}}+\mathrm{w}+\Theta_{\mathrm{m}} \mathrm{t}+\varepsilon_{\mathrm{nt}}
$$

where mindexes municipalities and tindexes years. O ur interest is the variables that compose the vector $\mathbf{X}_{\mathrm{nt}}$ which were constructed using information available in NASPT $(1911,1916,1919)$. Specifically, the vector $\mathbf{X}_{\text {nt }}$ includes separate indicators for whether municipality mwas served by a sanatorium, TB hospital, or an open-air camp in year t. Appendix Table 1 details when the first sanatorium, TB hospital, and open-air camp opened in each of the municipalities in our sample. ${ }^{24}$

The terms $v_{\mathrm{m}}$ and wrepresent municipality and year fixed effects, respectively. The municipality fixed effects control for municipal-level determinants of pulmonary TB mortality that were constant over time. The year fixed effects control for common shocks to pulmonary TB mortality, although it should be noted that there were no national newspapers or commercial radio

\footnotetext{
$22 \mathrm{On}$ average, each municipality contributed 13.6 observations to the analysis.

${ }^{23}$ By comparison, the U.S. mortality rate from all forms of TB was 222 per 100,000 population (U.S. Bureau of the Census 1908, p. 66).

${ }^{24}$ Note that Appendix Table 1 lists only municipalities for which we have TB mortality data both before andafter the particular anti-TB measure was established.
} 
broadcasts. Efforts to educate the public about TB and encourage good hygiene were undertaken entirely at the local (e.g., municipal) level until 1908, when the NASPT established a press service that released bulletins to newspapers and wire services (Teller 1988, p. 59). ${ }^{25}$ Throughout the period under study, magazines such as GoodHauskeeping Ladies HomeJaumal, and Popular SäeneMonthlyran stories promoting "antisepticonsciousness" (McClary 1980; Tomes 2000; 2002). Any effect these publications might have had on TB mortality is captured by the year fixed effects. In addition to the municipality and year fixed effects, we include municipality-specific linear time trends $\left(\Theta_{m^{*}}\right.$ t) to account for the possibility that pulmonary TB mortality rates evolved at different rates in municipalities that adopted anti-TB measures versus those that did not. Standard errors are corrected for clustering at the state level (Bertrand et al. 2004), although clustering at the municipal level produced almost identical results to those reported below.

After estimating the baseline regression, we augment the vector $\mathbf{X}_{\text {nt }}$ with an indicator for whether municipality mrequired the reporting of TB cases. By 1917, 91 municipalities in our sample had adopted ordinances requiring that active TB cases be reported to local health officials. ${ }^{26}$ We also include an indicator for whether the municipality was located in a state that required the reporting of TB cases, and separate indicators for whether the municipality required the disinfection of premises vacated by TB patients and whether it was located in a state that required disinfection.

Next, we augment the vector $\mathbf{X}_{\text {nt }}$ with an indicator for whether municipality mprohibited spitting in public. We also include separate indicators for whether it prohibited the common cup

\footnotetext{
25 Many state and local TB associations established their own press services after 1908 (Teller 1988, p. 59), but before then newspapers regularly covered the parades, exhibits, and Christmas seal campaigns sponsored by these associations (Tomes 2002). The first U.S. commercial radio broadcast occurred on November 2, 1920 (election night) in Pittsburgh. Up until then, radio stations were operated by amateur hobbyists whose target audience was composed of other hobbyists (Sterling and Kittross 2002, pp. 44-48 and p. 66).

${ }^{26}$ We observe mortality data before and after the adoption of a reporting ordinance for 71 of these cities (see Appendix Table 1).
} 
and whether it was located in a state with a common cup ban. Finally, we include separate indicators for whether municipality mhad a TB association, whether it was located in a state with a TB association, and whether it was served by a TB dispensary. ${ }^{27}$ D escriptive statistics and definitions for all of the variables used in the analysis are reported in Table $1 .^{28}$ Information on when these anti-TB measures were adopted is available in Appendix Tables 1 and 2.

\section{Results}

In the first column of Table 2, we report estimates from the baseline model, which focuses on the relationship between pulmonary TB mortality and the institutions explicitly designed to isolate and care for TB patients. While the estimated coefficients of the sanatorium and open-air camp indicators are negative, they are small in magnitude and not statistically distinguishable from zero. The relationship between pulmonary TB mortality and the TB hospital indicator is positive, but also insignificant.

In the second column of Table 2, we report estimates from a regression model that includes the reporting and disinfection indicators on the right-hand side. The adoption of a reporting requirement at the municipal level is associated with a 5.5 percent $\left(\mathrm{e}^{-.057}-1=-.055\right)$ decrease in the pulmonary TB mortality rate, an estimate that is statistically significant at the 5 percent level. By contrast, there is little evidence that state reporting requirements mattered: the estimated coefficient of the state reporting requirement indicator is small and insignificant. Likewise, there is little

\footnotetext{
27 Because we have the exact date on when state TB associations began operation, the first year of the state TB indicator is coded as a fraction. O ur definition of TB dispensaries also includes clinics where special medical staffs and separate hours were set aside for TB patients (NASPT 1911, 1916, 1919).

${ }^{28}$ Although not shown in Table 1, we also include binary indicators to control for missing information on the municipallevel anti-TB measures. For instance, if a city had a common cup ban but information on when the ban went into place was missing, we coded Common CupOrdnanceas equal to zero and included a separate indicator for this missing information. With one exception, each of our municipal-level anti-TB measures has non-missing information for at least 92 percent of the sample. We observe non-missing information for the municipal disinfection ordinances for 73 percent of the sample.
} 
evidence that disinfection requirements at either the municipal or state levels had an effect on pulmonary TB mortality.

In the third column of Table 2, we report estimates from a regression model that includes spitting and common cup bans on the right-hand side; in the fourth column, we report estimates from a regression model that includes the TB association indicators and an indicator for whether there was a dispensary in operation in municipality mand year $\mathrm{t}$. None of these anti-TB measures appear to have had an appreciable impact on the pulmonary TB mortality rate. The estimated coefficients are, without exception, small in magnitude and measured imprecisely. By contrast, the relationship between municipal reporting requirements and pulmonary TB mortality is negative, significant, and remarkably stable across these specifications. ${ }^{29}$

\subsection{A closer look at the role of sanatoriums}

Up to this point in the analysis, we have attempted to capture the effect of the sanatorium movement with a simple indicator of whether municipality mwas served by a sanatorium in year $\mathrm{t}$. However, the most populous cities in the United States were typically served by multiple sanatoriums by the end of the period under study. Moreover, private sanatoriums were often

\footnotetext{
${ }^{29}$ In Appendix Table 3, we report the results of regressing the natural log of pulmonary TB mortality on three separate anti-TB indices. In the first column of Appendix Table 3, we consider an index based on the sum of the state anti-TB measures listed in Table 1; in the second column, we consider an index based on the sum of the municipal anti-TB measures listed in Table 1; in the third column, we consider an index based on the sum of all of the anti-TB measures listed in Table 1. The results provide no evidence of a relationship between pulmonary TB mortality and these alternative measures of the intensity of the anti-TB movement. We also experimented with consolidating the variables on municipal- and state-level reporting requirements, disinfection requirements, common cup bans, and TB associations into four separate indicators. For example, we defined the reporting requirement variable as equal to one if the municipality or the municipality's state required the reporting of TB cases. None of these alternatively defined anti-TB measures were significantly associated with the pulmonary TB mortality rate. Lastly, we explored whether reporting requirements were more effective in municipalities that were served by a sanatorium. We found no evidence that the interaction between RepatingOrdmanceand Samatriumhad an effect on the pulmonary TB mortality rate.
} 
located in rural areas where air pollution, which was intense in industrial cities such as Chicago, Pittsburgh, and St. Louis (Stradling and Thorsheim 1999), would not interfere with recovery. ${ }^{30}$

In the first column of Table 3, we replace the sanatorium indicator with a continuous variable equal to the number of sanatoriums in municipality mat time $t^{31}$ In 1900 , only three municipalities in our sample were served by a sanatorium; by 1910, 37 of the municipalities in our sample were served by at least one sanatorium, 8 had at least two, and 4 had three or more; by 1917, 80 municipalities were served by at least one sanatorium, 13 had at least two, and 6 had three or more..$^{32}$

The estimated coefficient of the continuous sanatorium variable is positive, but not significant at conventional levels. In an effort to rule out reverse causality, we experimented with adding leads of the sanatorium variables to the regression model. There was no evidence that sanatoriums were opened in response to upswings (or downswings) in TB mortality. ${ }^{33}$

In column (2), we replace the sanatorium indicator with the number of sanatorium beds in municipality mat time $\mathrm{t}^{34}$ In our sample, the average sanatorium had a capacity of nearly 100 beds. However, the number of beds varied widely, with some sanatoriums serving fewer than 10 patients and others accommodating over 1,000. While the estimated coefficient on our measure of

\footnotetext{
30 Private sanatoriums catered to the affluent, but could be as large as publicly funded sanatoriums. For instance, the Agnes Memorial Sanatorium in Denver, CO accommodated over 150 patients in 1916, while the Sanatorium of the New Bedford Anti-Tuberculosis Association in New Bedford, MA accommodated over 100 patients (NASPT 1916).

31 We also experimented with using the number of sanatoriums per 100,000 population of municipality min year t, but found no evidence that this alternative measure was related to the pulmonary TB mortality rate.

32 We have pulmonary TB mortality data before and after the opening of a sanatorium for 70 of these cities (see Appendix Table 1).

33 These results are available upon request. We experimented with including 1-3 leads of the sanatorium indicator as well as including 1-3 leads of the continuous sanatorium measure. The estimated coefficients of these leads were consistently small and statistically insignificant. We found similar results when we experimented with using continuous variables for open-air camps and TB hospitals.
}

${ }^{34}$ We also experimented with using the number of beds per 100,000 population, but found no evidence that this measure was related to the pulmonary TB mortality rate. 
sanatorium capacity is negative in sign, it is small in magnitude and statistically indistinguishable from zero. ${ }^{35}$

In columns (3) and (4), we explore whether the opening of sanatoriums at the state, as opposed to the municipal, level had an effect on pulmonary TB mortality. Specifically, in column (3) we show the results of augmenting the baseline equation with an indicator for whether municipality mwas located in state with a sanatorium, and in column (4) we include the total number of sanatoriums operating in the state at time t. The results suggest that the opening of sanatoriums at the state level did little to curb the spread of pulmonary TB.

Finally, in column (5) of Table 3, we investigate the role of state-run sanatoriums. In 1900, there were no state-run sanatoriums in the country, but by the end of the period under study there were 29 in operation and they represented a substantial portion of total capacity (NASPT 1919). ${ }^{36}$ State-run sanatoriums were typically located in rural areas and were considered more desirable than county-run or municipal sanatoriums. Unlike other publicly funded sanatoriums, state-run sanatoriums often charged weekly fees to "keep out the riffraff" and prioritized admitting incipient TB cases over chronic or advanced cases (Rothman 1995, pp. 207-208). ${ }^{37}$

\footnotetext{
35 It should be noted that our sanatorium-bed measure is, because of data limitations, somewhat crude. We only observe sanatorium capacity at the three points in time corresponding to the publications of the NASPT's Tuberulosis Diretary (1911, 1916, and 1919). For the intervening years, we assume that capacity remained constant.
}

${ }^{36}$ According to Teller (1988, p. 82), there were 94 public sanatoriums operating in the United States by 1916. A total of 7,501 beds were available in state-run sanatoriums, 1,279 beds were available in federal sanatoriums, and 4,736 beds were available in municipal sanatoriums. By comparison, there were 87 private sanatoriums operating in the United States in 1916, with a total of 3,447 beds, and 42 philanthropic sanatoriums with a total of 2,711 beds (Teller 1988, p. 82). See Appendix Table 2 for information on when each state-run sanatorium opened during the period 1900-1917. We observe mortality data for 277 municipalities before and after the opening of 25 state-run sanatoriums.

${ }^{37}$ D r. Herbert Clapp, a supervising physician at the Massachusetts state-run sanatorium, described cases that should be refused admission:

No bedridden patients should be accepted, nor even those who are confined to their rooms. If an applicant is not strong enough to ride some distance to the examining office, it is cause enough for his rejection... No case of acute tuberculosis should be admitted, nor any case with high fever, nor even with a temperature which, after rest in bed with open windows for one or two weeks, does not come down to perhaps $100^{\circ}$ (Clapp 1906, pp. 342-343). 
The estimated effect of state-run sanatoriums is negative and significant, although relatively small in terms of magnitude. Specifically, the opening of a state-run sanatorium is associated with a 3.7 percent $\left(\mathrm{e}^{-.038}-1=-.037\right)$ reduction in the pulmonary TB mortality rate. This effect is explored in greater depth below.

\subsection{Extensions and robustness checks}

In Table 4, we present estimates of equation (1) augmented with leads and lags of the municipal reporting ordinance. Consistent with the parallel trends assumption, there is little evidence that pulmonary TB mortality increased in the years leading up to the passage of TB reporting requirements. Before Y ear 0 (the year in which doctors were required to report active TB cases to local health officials), estimates of the relationship between the reporting indicator and pulmonary TB mortality are small and statistically insignificant; after three years, these estimates are consistently negative and statistically significant at conventional levels. Three or more years after being adopted, the reporting ordinance is associated with a 9-12 percent decrease in pulmonary TB mortality. ${ }^{38}$

Previous studies have produced strong evidence that turn-of-the-century efforts to improve water quality led to substantial reductions in mortality from waterborne diseases (Troesken 2001; Cutler and Miller 2005; Ferrie and Troesken 2008; Beach et al. 2016). Moreover, there is evidence, albeit descriptive in nature, that these efforts reduced mortality from non-waterborne diseases,

\footnotetext{
38 In Appendix Table 4, we present estimates of equation (1) augmented with leads and lags of the state-run sanatorium indicator. Again, consistent with the parallel trends assumption, there is little evidence that pulmonary TB mortality increased in the years leading up to the opening of the first state-run sanatorium. By contrast, after 3 years it is associated with a 3-5 percent decrease in pulmonary TB mortality, although it should be noted that the estimated coefficient of the 3+ YersAfter StateRunSanatonumindicator is not consistently significant at conventional levels.
} 
including TB (Sedgwick and MacNutt 1910; McG ee, 1920). ${ }^{39}$ Although some contemporary

researchers suggested that tuberculosis might be transmitted through waste water (Brown et al. 1916; Fink et al. 1917), a more likely explanation for what was dubbed the "Mills-Reincke Phenomenon" is that typhoid and other gastronomical diseases weakened the host, increasing his or her susceptibility to infection from Mycobaderiumtuberalosis(Ferrie and Troesken 2008).

Because municipal chlorination and filtration projects could have been correlated with the adoption of TB reporting requirements, we included the mortality rate from typhoid on the righthand side of the estimation equation as a robustness check (Clay et al. 2014). The results of this exercise are reported in the first column of Table 5. Including the typhoid mortality rate as a proxy for water quality reduces the magnitude of the estimated relationship between municipal reporting requirements and pulmonary TB mortality. Specifically, requiring that TB cases be reported to local health officials is associated with a 4.9 percent decrease in pulmonary TB mortality, an estimate that is significant at the 10 percent level.

In column (2) of Table 5, we restrict our attention to municipalities with more than 50,000 residents. With this restriction in place, reporting requirements are associated with a 6.5 percent decrease in pulmonary TB mortality, which is slightly larger than the baseline estimates reported in Table 2. In column (3) of Table 5, we restrict our attention to municipalities with more than 50,000 residents and population densities in the top $50^{\text {th }}$ percentile..$^{40}$ Perhaps because overcrowding facilitated the spread of TB (Rothman 1995, pp. 184-185; Schmidt 2008), the estimated effect of reporting ordinances in column (3) is slightly larger than the baseline estimates in Table 2. Likewise,

\footnotetext{
39 See also Ferrie and Troesken (2008). Using data from Chicago for the period 1855-1925, these authors found a positive relationship between typhoid mortality and mortality from respiratory diseases. Specifically, an additional death from typhoid fever was associated with 1-1.5 additional deaths from tuberculosis and pneumonia.

${ }^{40}$ Information on population density for the 100 largest cities in 1910 is available from the U.S. Census Bureau at: http:// www.census.gov/ population/ www/ documentation/ twps0027/ tab14.txt.
} 
when we restrict the sample to municipalities with 18 years of non-missing data, the adoption of a reporting requirement is associated with a 6.8 percent decrease in the pulmonary TB mortality rate.

Reporting requirements were aimed at reducing the human-to-human transmission of pulmonary TB. In column (5) of Table 5, we test whether they were related to non-pulmonary TB, which was usually caused by contaminated milk (Teller 1988, pp. 67-68). ${ }^{41}$ Because the incidence of non-pulmonary TB mortality was much lower than that of pulmonary TB (and was, in fact, equal to zero for 716 municipality-year combinations), we take its quartic root instead of taking its natural $\log _{{ }^{42}}$ Reassuringly, requiring that TB cases be reported to local health officials is not associated with decreased mortality from non-pulmonary TB. In fact, the estimated marginal effect, although small relative to the mean of non-pulmonary TB mortality, is positive. By contrast, taking the quartic root of pulmonary TB mortality produces an estimated marginal effect that is similar in magnitude to the original estimate reported in Table 2.

In Table 6, we investigate the robustness of the negative relationship between the opening of a state-run sanatorium and pulmonary TB mortality. Controlling for typhoid mortality reduces the absolute magnitude of this relationship, but the estimated coefficient is still negative and significant at the 5 percent level. Likewise, restricting the sample to municipalities that contributed 18 years of data produces a slightly smaller estimate than that reported in Table 3, but it is still significant at conventional levels. Finally, while there is no evidence that state-run sanatoriums affected non-

\footnotetext{
41 In general, the TB movement was focused on eliminating human-to-human transmission of pulmonary TB and all but ignored bovine TB (Teller 1988, p. 69). Although, a handful of states required the tuberculin testing of dairy cows, bovine TB was not effectively controlled until after 1917, when the USD A undertook a campaign to eradicate the disease (O lmstead and Rhode 2004). Throughout the period under study, milk stations in New Y ork and other cities provided clean milk at a reduced price to poor mothers (Meckel 1990, pp. 78-80). In 1909, Chicago became the first municipality to require the pasteunzation of milk. By 1921, most large cities in the United States required pasteurization, which protected consumers from bovine TB and other milk-borne diseases such as typhoid (Meckel 1990, p. 89).

42 This method of dealing with zeros has been used by Thomas et al. (2006), Tarozzi et al. (2014) and Ashraf et al. (2015), among others. The marginal effect of requiring that TB cases be reported to local health officials is in brackets.
} 
pulmonary TB mortality, their impact appears to have been most pronounced in municipalities with more than 50,000 residents.

\section{WAS MORTALITY FROM OTHER AIRBO RNE DISEASE S AFFECTED?}

In Figure 2, we show trends in mortality for influenza/ pneumonia and other airborne illnesses, a broad grouping that includes mortality from measles, scarlet fever, whooping cough (i.e., pertussis), and diphtheria/ croup. Like pulmonary TB, these diseases are typically transmitted by aerosolized respiratory secretions (for instance, from coughing or sneezing). ${ }^{43}$ D uring the period 1900-1917, mortality from influenza/ pneumonia remained relatively stable, while the mortality rate from other airborne illnesses fell from 105.8 to 45.6.

Did the measures championed by the U.S. TB movement affect mortality from influenza/ pneumonia and/ or other airborne illnesses? Several anti-TB measures could have, in theory, reduced mortality from other diseases transmitted through respiratory secretions. Indeed, the Centers for D isease Control still recommends frequent hand washing and the covering of coughs to prevent the spread of germs, and would presumably frown upon public spitting and the use of common cups. Although the threat of TB has receded and anti-spitting laws are no longer enforced in the United States (York 2003; Williams 2015), authorities in Beijing, London, and Mumbai have justified recent efforts to discourage spitting on public health grounds (Yardley 2007; Pettitt 2015; Sujit and Iyer. 2015).

In the first column of Table 7, we report results from regressing mortality due to influenza and pneumonia on the spitting law and common cup indicators. In addition, we control for whether municipality mhad a TB association and whether it was located in a state with a TB association.

${ }^{43}$ D uning the period under study, there were no effective vaccines or cures for influenza, measles, scarlet fever, or whooping cough (Q uinn 1989; Roush and Murphy. 2007; Cowling et al. 2013; Cherry 2015). However, diphtheria could be treated using a horse-derived antitoxin (Wagner et al. 2009). 
This exercise produces no support for the notion that spitting laws, common cup ordinances, or efforts on the part of TB associations to educate the public and legislate its behavior had an impact on mortality due to influenza and pneumonia. When we include the other anti-TB measures (e.g., the sanatorium and TB hospital indicators) on the right-hand side of the regression, the results are similar. However, we do find some evidence that municipal spitting laws may have led to small reductions in the influenza and pneumonia mortality rate.

Next, we examine the effects of anti-TB measures on mortality from other airborne illnesses (i.e., measles, scarlet fever, whooping cough, and diphtheria/ croup). The results provide little support for the notion that the adoption of anti-TB measures contributed to the dramatic reduction in mortality due to these illnesses documented in Figure $2 .^{44}$

\section{GAUgING THE OVERALL IMPACT OF THE TB MOVEMENT}

We begin this section with an examination of municipal reporting requirements and their contribution to the overall decline in pulmonary TB mortality. As noted above, 91 municipalities in our sample had adopted ordinances requiring that active TB cases be reported to local health officials by 1917; the adoption of such an ordinance is associated with an approximately 6 percent decline in the pulmonary TB mortality rate (Table 2).

To gauge the impact of reporting ordinances, we calculated what the pulmonary TB mortality rate would have been had none of the municipalities in our sample required reporting of active TB cases. Figure 3 shows the predicted pulmonary TB rate for every year $\mathrm{t}$ (and its 90 percent confidence interval) under this scenario. Predicted pulmonary TB mortality rates are based on the

\footnotetext{
${ }^{44}$ Because deaths from TB were, with some frequency, attributed to bronchitis, malaria, and/ or pneumonia (Cabot 1900, p. 27; Cabot 1912), we experimented with including these diseases in Other AirbomeIllnesses Matality. The estimates reported in Table 7 changed very little when using this alternative definition.
} 
regression estimates in column (4) of Table 2. The actual pulmonary TB mortality rate among the municipalities that compose our sample is also provided.

The actual and predicted pulmonary TB mortality rates are not far apart throughout the period under study, suggesting that the ordinances did not contribute substantially to the observed overall decline in pulmonary TB mortality. By 1917, the actual pulmonary TB mortality rate among municipalities in our sample was 125 per 100,000 population, its lowest level during the period under study. Had no municipality adopted a reporting ordinance, we predict that it would have been 128 per 100,000 population. Even using the upper bound of the 90 percent confidence interval, we predict that the pulmonary TB mortality rate would have fallen from 173 to 132 had no reporting ordinances been adopted.

Finally, we use a similar strategy, and the regression estimates in column (4) of Table 2, to gauge the combined contribution of all the anti-TB measures adopted during the period under study (Figure 4). From 1900 to 1917, the pulmonary TB mortality rate among the municipalities in our sample fell by nearly 28 percent, from 173 to 125 per 100,000 population. Had no anti-TB measures been adopted, we predict that the pulmonary TB mortality rate would have been 122 per 100,000 population in 1917. Using the upper bound of the 90 percent confidence interval, we predict that the pulmonary TB mortality rate would have still fallen by 22 percent, to 135.5 per 100,000 population, had no anti-TB measures been implemented at either the municipal or state levels.

\section{Conclusion}

One out of every 4 people alive today has a latent tuberculosis (TB) infection (Houben and D odds 2016). Most TB infections, if they become active, can be successfully treated with antimicrobial medicines, but the WHO (2015, p. 56) estimates that 3.3 percent of new TB cases are 
multidrug-resistant. ${ }^{45}$ With experts warning that multidrug-resistant strains of TB represent a "looming public health crisis" (Frieden 2015), it is perhaps more important than ever that we accurately assess the effectiveness of basic, "low-tech" public health measures, many of which were pioneered by the TB movement.

The U.S. TB movement can be traced to the establishment of the Pennsylvania Society for the Prevention of Tuberculosis in 1892 (Shryock 1957, p. 52); it gained momentum with the founding of the National Association for the Study and Prevention of Tuberculosis (NASPT) in 1904. Between 1904 and 1917, hundreds of state and local TB associations were established across the country with the goal of educating the public and providing support to sanatoriums, TB hospitals, and open-air camps. TB associations also advocated for the passage of legislation aimed at curbing the spread of TB. Such legislation included bans on public spitting and requirements that active TB cases be reported to health officials. Reporting requirements prevented physicians from concealing TB diagnoses and allowed public health officials to monitor TB patients (Teller 1988, p. 22).

D espite the remarkable scope and influence of the TB movement, its effect on TB mortality has not been studied in a systematic fashion. In fact, many historians appear to believe that gauging the impact of the TB movement on TB mortality is impossible. For instance, Bates (1989, p. 349) wrote that, "in the absence of controlled studies," we may never know "whether or to what degree the tuberculosis movement contributed to the declining death rate in the United States or improved the health of tuberculosis patients." Experts from other disciplines have also expressed skepticism regarding the effectiveness of the TB movement (McKeown 1976; Coker 2003; D aniel 2006).

\footnotetext{
${ }^{45}$ Multidrug-resistant TB is caused by the bacteria adapting to the drugs typically used to treat it, making them ineffective. The recommend treatment for drug-susceptible TB lasts six-months, but treatment for multidrug-resistant TB takes 20 months, requires more toxic drugs, and has a much lower success rate (WHO 2015, p. 4).
} 
Using newly digitized mortality data at the municipal-year level, we explore the effect of the TB movement on pulmonary TB mortality. We find strong evidence that requiring TB cases to be reported to local health officials led to a 6 percent reduction in the pulmonary TB mortality rate, lending support to the argument that addressing the under-notification problem is critical to the success of anti-TB efforts in developing counties today (Uplekar et al. forthcoming). We also find that the establishment of a state-run sanatorium led to an almost 4 percent reduction in the pulmonary TB mortality rate. By contrast, there is no evidence that other anti-TB measures (for instance, requiring the premises of deceased TB patients to be disinfected or the prohibition of common drinking cups) were effective.

Finally, to gauge the overall effect of the TB movement, we calculated what the pulmonary TB mortality rate would have been had no anti-TB measures been implemented. D uring the period under study, the pulmonary TB mortality rate among the municipalities in our sample fell by nearly 28 percent, from 173 to 125 per 100,000 population. Had no anti-TB measures been adopted, we predict that the pulmonary TB mortality rate would have been 122 per 100,000 population in 1917. Using the upper bound of the 90 percent confidence interval, we predict that the pulmonary TB mortality rate would have still fallen by 22 percent, to 135.5 per 100,000 population, had the TB movement never occurred. Based on these estimates, we conclude that the basic anti-TB measures employed during the early 1900s did not contribute substantially to the marked decline in the TB mortality rate. 


\section{REFERENCES}

Abel, Emily K. 2007. Tubaralosis and thePditics of Exdusion: A Histary of PublicHealthandMigationto Los Angdes New Brunswick: Rutgers University Press.

Ambler, C.P. 1903. "Should the TB Patient Know the Truth Regarding His Condition?” JAMA, 41(12): 656-657.

Alsan, Marcella and Claudia G oldin. 2015. "Watersheds in Infant Mortality: The Role of Effective Water and Sewerage Infrastructure, 1880 to 1915." NBER Working Paper No. 21263.

Armstrong, G regory L., Laura A. Conn, and Robert W. Pinner. 1999. "Trends in Infectious Disease Mortality in the United States during the 20th Century." JAMA, 281(1): 61-66.

Ashraf, Nava, Diego Aycinena, Claudia Martinez and D ean Yang. 2015. "Savings in Transnational Households: A Field Experiment among Migrants from El Salvador." Reiewof Economics and Statistics, 47(2): 332-351.

Bates, Barbara. 1989. "The Tuberculosis Movement: A Public Health Campaign in the Progressive Era by Michael E. Teller." Isis 80(2) 349-350.

Bates, Barbara. 1992. Bargainingfor Life A Social Histay of Tubaculosis, 1876-1938. Philadelphia: University of Pennsylvania Press.

Beach, Brian, Joseph Ferrie, Martin Saavedra, and Werner Troesken. 2016. "Typhoid Fever, Water Quality, and Human Capital Formation." Jaumal of Econamic Histary, 76(1): 41-75.

Bloede, Victor G. 1908. "A Comprehensive Plan to the Treatment of the Tuberculosis Problem." Bullein of theJdhns Hopkins Hospital, 19(213):349-352.

Bignall, J.R. 1977. "Treating Tuberculosis in 1905: The First Patients at the Brompton Hospital Sanatorium." Tubade, 58(1): 43-52.

Bootsma, Martin C. J. and Neil M. Ferguson. 2007. "The Effect of Public Health Measures on the 1918 Influenza Pandemic in U.S. Cities." Procedings of theNational Acadamy of Saienes of theUnited States of America, 104(18): 7588- 7593.

Boudreau, Frank. 1920. "What the Teacher Can D o to Conserve Health and Prevent D isease in School Children." TheOhioPubicHe日lthJamal, 11(9-10): 149-155.

Brown, Lawrason, 1908. "An O utline for a Coordinated Attack upon Tuberculosis." NewYork Medical Jaumal, 90(20): 1003-1007.

Brown, Lawrason, S.A. Petroff, and F.H. Heise. 1916. "The Occurrence of Living Tubercle Bacilli in River Water Contaminated by Sewage from a Health Resort." AmericanJaumal of PublicHe日lth 6(11): 1148-1152. 
Bynum, Helen. 2012. SpittingBlood TheHistay of Tubaalosis New Y ork, NY: O xford University Press.

Cabot, Richard C. 1900. Physical Diagnosis of D iseases of the Chest. New York: William Wood and Company.

Cabot, Richard C. 1908. "Justifiable Lying." Amærican PrimaryTeader, 32(8): 286-287.

Cabot, Richard C. 1912. "D iagnostic Pitfalls Identified during a Study of Three Thousand Autopsies." JAMA, 59 (26):2295-2298.

Cherry, James D . 2015. "The History of Pertussis (Whooping Cough); 1906-2015: Facts, Myths, and Misconceptions." Curett EpidamidogyRepats 2(2): 120-130.

Clapp, Herbert C. 1906. "What Cases are Suitable for Admission to a State Sanatorium for Tuberculosis, Especially in New England?" National Association for the Study and Prevention of Tuberculosis, Transactions of the First Annual Meeting, Washington, D .C., pp. 339-348.

Clay, Karen, Werner Troesken and Michael Haines. 2014. "Lead and Mortality." Reviewof Economics and Statistics, 96(3): 458-470.

Coker R.J. 2003. "Public Health Impact of D etention of Individuals with Tuberculosis: Systematic Literature Review." PublicHølth 117(4): 281-287.

Colgrove, James. 2002. "The McKeown Thesis: A Historical Controversy and Its Enduring Influence." AmericanJamal of PublicHelth 92(5): 725-729.

Colorado (state). 1914. "Tuberculosis. Notification of Cases and Control of (Chap. 125, Act Mar. 17, 1913)." PublicHelth Repats (1896-1970), 29(10): 593-595.

Condran, G retchen A. and Eileen Crimmins-Gardner. 1978. "Public Health Measures and Mortality in U.S. Cities in the Late Nineteenth Century." Human Eøogy, 6(1): 27-54.

Condran, G retchen A. and Rose A. Cheney. 1982. "Mortality Trends in Philadelphia: Age- and Cause-Specific D eath Rates 1870-1930.” Demogaphy, 19(1): 97-123.

Cowling, Benjamin J., D ennis K. M. Ip, Vicky J. Fang, Piyarat Suntarattiwong, Sonja J. O lsen, Jens Levy, Timothy M. Uyeki, Gabriel M. Leung, J. S. Malik Peiris, Tawee Chotpitayasunondh, Hiroshi Nishiura, and J. Mark Simmerman. 2013. "Aerosol Transmission is an Important Mode of Influenza A Virus Spread.” NatureCommmications, 4.

Crowe, Morgan. 1947. "The Tuberculosis D ispensary.” InishJaumal of Medical Saiene, 22(7): 465-470.

Cutler, D avid M. and G rant Miller. 2005. "The Role of Public Health Improvements in Health Advances: The Twentieth-Century United States." Demogaphy, 42(1), pp. 1-22.

Cutler, D avid M., Angus D eaton and Adriana Lleras-Muney. 2006. "The D eterminants of Mortality." Jamal of EcanomicPespeetives 20(3): 97-120. 
D aniel, Thomas M. 2000. Pionersin Medineand their Impact on Tuberalosis Rochester, NY: University of Rochester Press.

D aniel, Thomas M. 2006. "The History of Tuberculosis." Respiratary Mediane, 100(11): 1862-1870.

D heda, Keertan and Giovanni B. Migliori. 2012. "The G lobal Rise of Extensively D rug-Resistant Tuberculosis: Is the Time to bring Back Sanatoria Now Overdue? Lanct, 379(9817): 773-775.

D onald, Peter. 2016. "A Brief History of Childhood Tuberculosis." In the Handbook of Childand Addescent Tubaralosis, Jeffrey R. Starke, Peter R. D onald, eds. New York: O xford University Press, pp. 1-11.

Emerson, Haven. 1922. "The Causes of the Rapidly Increasing Fall of the Tuberculosis D eath Rate in the Last Five Y ears." Jaumal of Outdbor Life, 19(12), pp. 247-254.

Fairchild, Amy L. and Gerald M. Oppenheimer. 1998. "Public Health Nihilism versus Pragmatism: History, Politics, and the Control of Tuberculosis." AmericanJaumal of PubicHelth 88(7): 1-14.

Ferrie, Joseph and Werner Troesken. 2008. "Water and Chicago's Mortality Transition, 1850- 1925." Explarations inEconamicHistary, 45(1): 1-16.

Feldberg, G eorgina D . 1995. DiseseandClass: Tuberaulosis and theShapingof Modam NathAmerican Socidy. New Brunswick: Rutgers University Press.

Fink, Emanuel B. 1917 “American Mortality Statistics and the Mills-Reincke Phenomenon." The Jaumal of Infetiaus Diseses, 21(1): 62-94.

Flick, Lawrence F. 1912. "The Economical Administration of the Crusade against Tuberculosis." Lipinatts Magazine, 91(A pril): 439-447.

Fox, D aniel. 1975. "Social Policy and City Politics: TB Reporting in New York City 1889-1900". BHM, 49(summer): 169-196.

Fraser, A. Mearns and Hilda Clark. 1912. "A Municipal Dispensary and Tuberculin Treatment." The Lanet, 180(4640): 289-293.

Frieden, Thomas. 2015. "D rug Resistant Tuberculosis: The Next G lobal Health Crisis?"

Testimony - House Foreign Affairs Committee, Subcommittee on Africa, Global Health, Global Human Rights, and International Organizations, D ecember 8, 2015. Available at:

https:/ / www.cdc.gov/ washington/ testimony/ 2015/ t20151208.htm

G arrett, Laurie. 1994. TheComingPlague NentyEmegingDises in a Wodd Out of Balance New York, NY: Farrar, Straus, and Giroux.

Gideon, Hannah P. and JoAnne L. Flynn 2011. "Latent Tuberculosis: What the Host 'Sees'?" ImmundogicRestron 50(2): 202-212. 
Girdwood, John. 1910. “A D octor's D uty in Tuberculosis.” NewYork Meeical Jamal, 92(8): 709-712.

Gladden, Fred. 1921. “The Principles of Health Control.” TheEducatar-Jamal, 21 (5): 272-274.

Hansen, Casper Worm, Peter Sandholt Jensen, and Peter Egedesø Madsen. 2017. "Preventing the White D eath: Tuberculosis D ispensaries." Working paper, University of Copenhagen. Available at: https:/ / sites.google.com/ site/ casperwormhansen/ home/ test.

Hollingsworth, Alex. 2014. "Controlling TB in a World without Antibiotics: Isolation and Education in North Carolina, 1932-1940." Working paper, Indiana University. Available at:

http:// alexjhollingsworth.com/ research/.

Houben Rein M. G. J. and Peter J. D odd. 2016. "The G lobal Burden of Latent Tuberculosis Infection: A Re-estimation Using Mathematical Modelling." PLOS Mediane Available at: http:/ / dx.doi.org/ 10.1371/ journal.pmed.1002152

Hutchinson, Woods. 1911. "For the Extermination of Tuberculosis in New York City." TheSurvey, 26(May): 297-299.

Jacobs, Philip P. 1921. "Organization for the Prevention and Control of Tuberculosis in the United States." Jaumal of Outdbor Life, 18(1): 10-14.

Jones, D avid S. and Jeremy A. G reene. 2013 "The D ecline and Rise of Coronary Heart D isease: Understanding Public Health Catastrophism." AmericanJarmal of PubicHelth, 103(7):1207-1218.

Jones, D avid S., Scott H. Podolsky, and Jeremy A. Greene. 2012. "The Burden of D isease and the Changing Task of Medicine." NewEngandJaumal of Meeiaine, 366(25): 2333-2338.

Katona, Peter and Judit Katona-Apte. 2008. "The Interaction between Nutrition and Infection." Clinical Infectious Diseases, 46(10): 1582-1588.

Klebs, Amold. 1909. "Economic and Efficient Construction." In the Transadions of theFifthAnnual Meting of theNational Assaiation for theStudy and Prevention of Tuberailosis Philadelphia: William F. Fell Company, pp. 126-141.

Knopf, Adolphus. 1901. Tuberaulosis as a Diseof theMasses and Howto Conbat It (first edition). New York, NY: Arno Press.

Knopf, Adolphus. 1908. "The Popular Lecture in the Crusade against Tuberculosis." In the Transadions of theSixthIntemational Congess on Tuberalosis Philadelphia: WM. F. Fell. Printers, pp. 661-673.

Knopf, Adolphus. 1911. Tuberalosis as a Diseof theMasses, andHouto Conbat It (seventh edition). New York, NY: The Survey.

Knopf, Adolphus. 1922. A Histary of theNational TBAssoiation Philadelphia: WM. F. Fell. Printers. 
Kolata, G ina. 2016. "A Medical Mystery of the Best Kind: Major D iseases Are in D ecline." New York Times July 8. Available at:

http:/ / www.nytimes.com/ 2016/ 07/ 10/ upshot/ a-medical-mystery-of-the-best-kind-major-diseasesare-in-decline.html.

Kunitz, Stephen J. 2007. TheHelth of Populations General Theeries andPartiallar Re⿻lities New Y ork, NY: Oxford University Press.

Lange, Christoph, Ibrahim Abubakar, Jan-Willem C. Alffenaar, Graham Bothamley, Jose A. Caminero, Anna Cristina C. Carvalho, K wok-Chiu Chang, Luigi Codecasa, Ana Correia, Valeriu Crudu, Peter D avies, Martin D edicoat, Francis D robniewski, Raquel D uarte, Cordula Ehlers, Connie Erkens, D elia G oletti, Gunar G ünther, Elmira Ibraim, Beate Kampmann, Liga Kuksa, Wiel de Lange, Frank van Leth, Jan van Lunzen, Alberto Matteelli, Dick Menzies, Ignacio Monedero, Elvira Richter, Sabine Rüsch-G erdes, Andreas Sandgren, Anna Scardigli, Alena Skrahina, Enrico Tortoli, G rigory Volchenkov, Dirk Wagner, Marieke J. van der Werf, Bhanu Williams, Wing-Wai Y ew, JeanPierre Zellweger, and D aniela Maria Cirillo. 2014. "Management of Patients with MultidrugResistant/ Extensively D rug-Resistant Tuberculosis in Europe: A TBNET Consensus Statement." European RespirataryJauml, 44(1): 23-63.

Lawn, Stephen D . and Alimuddin I. Zumla. 2011. “Tuberculosis.” Lanet, 378(9785): 57-72.

Lee, R. Alton. 2007. FromSnakeOil toMediane PioneringPublicHelth Westport, CT: Praeger Publishers - Greenwood Publishing Group Inc.

Mahamulkar, Sujit and Malathy Iyer. 2015. "Caught Spitting? D o Social Work for a D ay, Pay Rs 1,000." Times of India, June 16. A vailable at:

http:/ / timesofindia.indiatimes.com/ city/ mumbai/ Caught-spitting-D o-social-work-for-a-day-pay-

Rs-1000/ articleshow/ 47696047.cms.

McClary, Andrew. 1980. "G erms are Everywhere: The Germ Threat as Seen in Magazine Articles 1890-1920." TheJaumal of Ameican Culture, 3(1): 33-46.

McCuaig, Katherine. 1999. Weainess, theFeer, and theFre: TheCampaign against Tuberalosis in Canada, 1900-1950. Montreal, Q uebec: McG ill-Q ueen's University Press.

McG ee, Harold G. 1920. "Mills- Reincke Phenomenon and Typhoid Control by Vaccine." A meican Jaumal of PudicHelth 10(7): 585-587

McG uire, Michael. 2012. "100 Y ears of O utlawing the Common Cup." Safechinkingnater.com O ctober 29. Available at:

https:/ / safedrinkingwaterdotcom.wordpress.com/ 2012/ 10/ 29/ 100-years-of-outlawing-thecommon-cup/.

McKeown, Thomas. 1976. TheModanRiseof Pquilation New Y ork, NY: A cademic Press.

Meckel, Richard A. 1990. SavetheBabies: Amtican PublicHelth Reormand thePretetion of Infant Matality, 1850-1929. Baltimore: Johns Hopkins University Press. 
Mercer, Alexander. 2014. Infetions, Chronic Disese, and theEpidanidogical Transition: A NewPespetive Rochester NY: University of Rochester Press.

NASPT. 1911. A Tuberailosis Diretary. New York, NY: The National Association for the Study and Prevention of Tuberculosis.

NASPT. 1916. A Tuberalosis Diretary. New York, NY: The National Association for the Study and Prevention of Tuberculosis.

NASPT. 1919. A Tuberailosis Diretary. New York, NY: The National A ssociation for the Study and Prevention of Tuberculosis.

National Center for Health Statistics. 2016. Helth, United States, 2015: With Speial Featureof Racial and EthnicDispanities Hyattsville, MD : U.S. G overnment Printing O ffice.

Newsholme, Arthur. 1908. "The Causes of the Past D ecline in Tuberculosis and the Light Thrown by History on Preventive Measures for the Immediate Future. In A Seies of PudicLectures Speeially Prepared for theCongess Philadelphia: WM. F. Fell. Printers, pp. 80-109.

Newton, Robert J. 1910. "The Enforcement of Anti-Spitting Laws." In the Transadions of theSixth Intemational Congess on Tuberalosis Philadelphia: WM. F. Fell. Printers, pp. 109-121.

Nydegger, J.A. 1917. “Hygiene of Rural Schools.” NewYak Medical Jaumal, 106(11): 505-508.

Olmstead, Alan and Paul Rhode. 2004. "An Impossible Undertaking: The Eradication of Bovine Tuberculosis in the United States." Jaumal of EcanmicHistary, 64(3): 734-772.

O 'Connor, Patrick J., .2015. “'Spitting Positively Forbidden': The Anti-Spitting Campaign, 18961910." Theses Dissetations, Professional Papess Paper 4449.

Pettitt, Josh. 2015. “Spitting Fines Raise £55,000: Hundreds Forced to Pay up Over 'D eeply Unpleasant' Habit." The Evening Standard, February 6. Available at:

http:/ / www.standard.co.uk/ news/ london/ over-55000-raised-as-councils-begin-giving-fines-forspitting-on-the-streets-of-london-10027699.html.

Paterson, Robert. 1947. "The Evolution of O fficial Tuberculosis Control in the United States." PublicHelthRepats, 62(10): 336-341.

Quinn, Robert W. 1989. "Comprehensive Review of Morbidity and Mortality Trends for Rheumatic Fever, Streptococcal D isease, and Scarlet Fever: The D ecline of Rheumatic Fever."

Reviens of Infetiaus Diseses 11(6): 928-953.

Rappold, Scott. 2007. “America's G reatest Sanitarium” TheCdaradbSprings Gazdte, June 17. Available at:

http:/ / gazette.com/ americas-greatest-sanitarium/ article/ 23729.

Robbins, Susane F. 1906. "The D ay Camp for Tuberculosis Patients." TheAmmican Jaumal of Nursing 6(9): 593-597. 
Roberts, Samuel Kelton. 2009. Infetiaus Fer. Pditics, Dises, and theHœlthEffets of Segegation Chapel Hill, NC: University of North Carolina Press.

Rothman Sheila M. 1995. Liuingin theShadbwof Deeth Tuberailosis and theSoial Experieneof Illness in American Histary. Baltimore: Johns Hopkins University Press.

Roush, Sandra W. and Trudy V. Murphy. 2007. Historical Comparisons of Morbidity and Mortality for Vaccine-Preventable D iseases in the United States. JAMA, 298(18):2155-2163.

Rutledge, J.A., and John B. Crouch. 1919. "The Ultimate Results in 1654 cases of Tuberculosis Treated at the Modem Woodmen of America Sanatorium." American Rexiewof Tubaralosis, 2(12): 75563.

Sattar, A tia. 2016. “Germ Wars: Dirty Hands, D rinking Lips, and Dixie Cups.” In Jonathan Eburne and Judith Roof (eds.), TheYæar'sWork in theOddball Archive Bloomington, IN: Indiana University Press.

Schmidt, Charles W. 2008. "Linking TB and the Environment: An Overlooked Mitigation Strategy." EnMronmetal HealthPespeetives 116(11): A478-A485.

Sedgwick, William T. 1902. Priniples of Sanitary Saieneand thePublicHe日lth: With Speial Referenes tothe Causation andPrevetion of Infetiaus Dise New Y ork, NY: The McMillan Company.

Sedgwick, William T. and J. Scott MacNutt. 1910. "On the Mills-Reincke Phenomenon and Hazen's Theorem Concerning the Decrease in Mortality from Diseases other than Typhoid Following the Purification of Public Water Supplies." Jaumal of Infetiaus Dises 7, 564-589.

Shryock, Richard Harrison. 1957. National TuberulosisAssoiation, 1904-1954 A Study of theV duntary HealthMovenet in theUnited States New Y ork: National Tuberculosis A ssociation.

Smith, Issar. 2003. "Mycobacterium Tuberculosis Pathogenesis and Molecular D eterminants of Virulence." Cinical Mirdadogy Reiens, 16(3): 463-496.

Sterling, Christopher H. and John Michael Kittross. 2002. StayTuned A Histaryof American Broadkasting Mahwah New Jersey: Erlbaum Associates, Publishers.

Stradling, D avid and Peter Thorsheim. 1999. "The Smoke of G reat Cities: British and American Efforts to Control Air Pollution, 1860-1914." Environmental History, 4(1): 6-31.

Swedlund, Alan C. and Alison K. D onta. 2002. "Scarlet Fever Epidemics of the Nineteenth Century: A Case of Evolved Pathogenic Virulence?" In HumanBidogistsin theArdives Demogaphy, Helth, Nutrition, andGenticsin Histarical Popilations, D . Ann Herring and Alan C. Swedlund, eds. Cambridge: Cambridge University Press, pp. 159-177.

Tarozzi, Alessandro, Aprajit Mahajan, Brian Blackburn, D an Kopf, Lakshmi Krishnan and Joanne Yoong. 2014. "Micro-loans, Insecticide-Treated Bednets, and Malaria: Evidence from a Randomized Controlled Trial in O rissa, India." AmeicanEconomicReiew, 104(7): 1909-1941. 
Teller, Michael E. 1988. TheTuberailosis Movenet: A PublicHęlth Campaignin theProgessiveEra New York: G reenwood Press.

Thomas, D uncan, Elizabeth Frankenberg, Jed Friedman, Jean-Pierre Habicht, Mohammed Hakimi, Nicholas Ingwersen, Jaswadi, Nathan Jones, Christopher McK elvey, Gretel Pelto, Bondan Sikoki, Teresa Seeman, James Smith, Cecep Sumantri, Wayan Suriastini and Siswanto Wilopo. 2006. "Causal Effect of Health on Labor Market O utcomes: Experimental Evidence." CCPR-070-06. Available at: http:/ / escholarship.org/ uc/ item/ Og28k77w.

Thompson, Brian C. 1943. "Survival Rates in Pulmonary Tuberculosis." TheBritish Medical Jarmal, 2(4326): 721.

Tiemersma, Edine, Marieke van der Werf, Martien Borgdorff, Brian Williams and Nico Nagelkerke. 2011. "Natural History of Tuberculosis: D uration and Fatality of Untreated Pulmonary Tuberculosis in HIV Negative Patients: A Systematic Review." PLoS ONE, 6(4): e17601.

Tomes, Nancy J. 1989. "The White Plague Revisited.” Bullein of theHistay of Medidine, 63(3): 467-480.

Tomes, Nancy. 1998. TheGospd of Gems Men, Women, and theMiadbeinAmericanLife Cambridge, MA: Harvard University Press.

Tomes, Nancy. 2000. "The Making of a Germ Panic, Then and Now." AmericanJaumal of Public Health, 90(2): 191-198.

Tomes, Nancy. 2002. "Epidemic Entertainments: D isease and Popular Culture in Early-TwentiethCentury America." AmeicanLiteraryHistary, 14(4): 625-652.

Townsand, D avid. 1909. "D ay Camp Treatment for Tuberculosis." AmericanJamal of PudicHygiene, 19(4): 754-757.

Troesken, Werner. 2001. "Race, Disease and the Provision of Water in American Cities, 18891921." Jaumal of EcanomicHistary, 61(3): 750-776.

Uplekar, Mukund, Sachin A tre, William A. Wells, Diana Weil, Rafael Lopez, Giovanni Battista Migliori and Mario Raviglione. "Mandatory Tuberculosis Case Notification in High TuberculosisIncidence Countries: Policy and Practice." Forthcoming at Eurquean RespirataryJaumal.

U.S. Bureau of the Census. 1908. Tuberalosis in theUnited States Washington: G overnment Printing Office.

Vallejo, California (city). "Tuberculosis. Reporting of Cases of. Precautions to Prevent Infection. (Ord. 101 N. S., Aug. 24, 1912)." Public HellthReats(1896-1970), 28(52): 2879-2882.

Vynnycky, E., and P. E. Fine. 1999. "Interpreting the D ecline in Tuberculosis: The role of Secular Trends in Effective Contact." Intemational Jamal of Epidanidogy, 28(2): 327-334. 
Wagner, K.S., P. Stickings, J.M. White, S. Neal, N.S. Crowcroft, D . Sesardic, and A. Efstratiou. 2009. "A review of the international issues surrounding the availability and demand for diphtheria antitoxin for therapeutic use." Vacine, 28(1); 14-20.

Waters, Bertram, H. 1912. "Adequate Hospital Control." In the Transadions of theEigthAnnual Meting of theNational Assoiation for theStudy and Prevention of Tuberailosis Philadelphia: WM. F. Fell. Printers, pp. 245-250.

Wethered, Frank J. 1906. "The Sanatorium Treatment of Pulmonary Tuberculosis." TheLanct, 167 (4297): 7-11.

Williams, Brandt. 2015. “A re Minneapolis Laws that Ban Sitting 'Lurking' Racist?” Mimesda Pudic RadioNens, April 3. Available at:

https:/ / www.mprnews.org/ story/ 2015/ 04/ 03/ spitting-laws.

Wilson, Leonard G. 1990. "The Historical D ecline of Tuberculosis in Europe and America: Its Causes and Significance." Jaumal of theHistarial Medical Allied Saiene, 45 (3):366-396

Wilson, Leonard G . 2005. "Medicine, Population and Tuberculosis." Intemational Jaumal of Epidamidogy, 34 (3): 521-524.

World Health Organization 2015. 2015 Gldbal Tuberalosis Repat G eneva, Switzerland: WHO Press. Yardley, Jim. 2007. "No Spitting on the Road to O lympic G lory, Beijing Says." New York Times, April 17. Available at:

http:/ / www.nytimes.com/ 2007/ 04/ 17/ world/ asia/ 17manners.html.

York, Michelle. 2003. "Palmyra Journal; Penalties for Spitting, And a Bit of Snickering." TheNew York Times July 13. Available at:

http:/ / www.nytimes.com/ 2003/ 07/ 13/ nyregion/ palmyra-journal-penalties-for-spitting-and-a-bitof-snickering.html. 


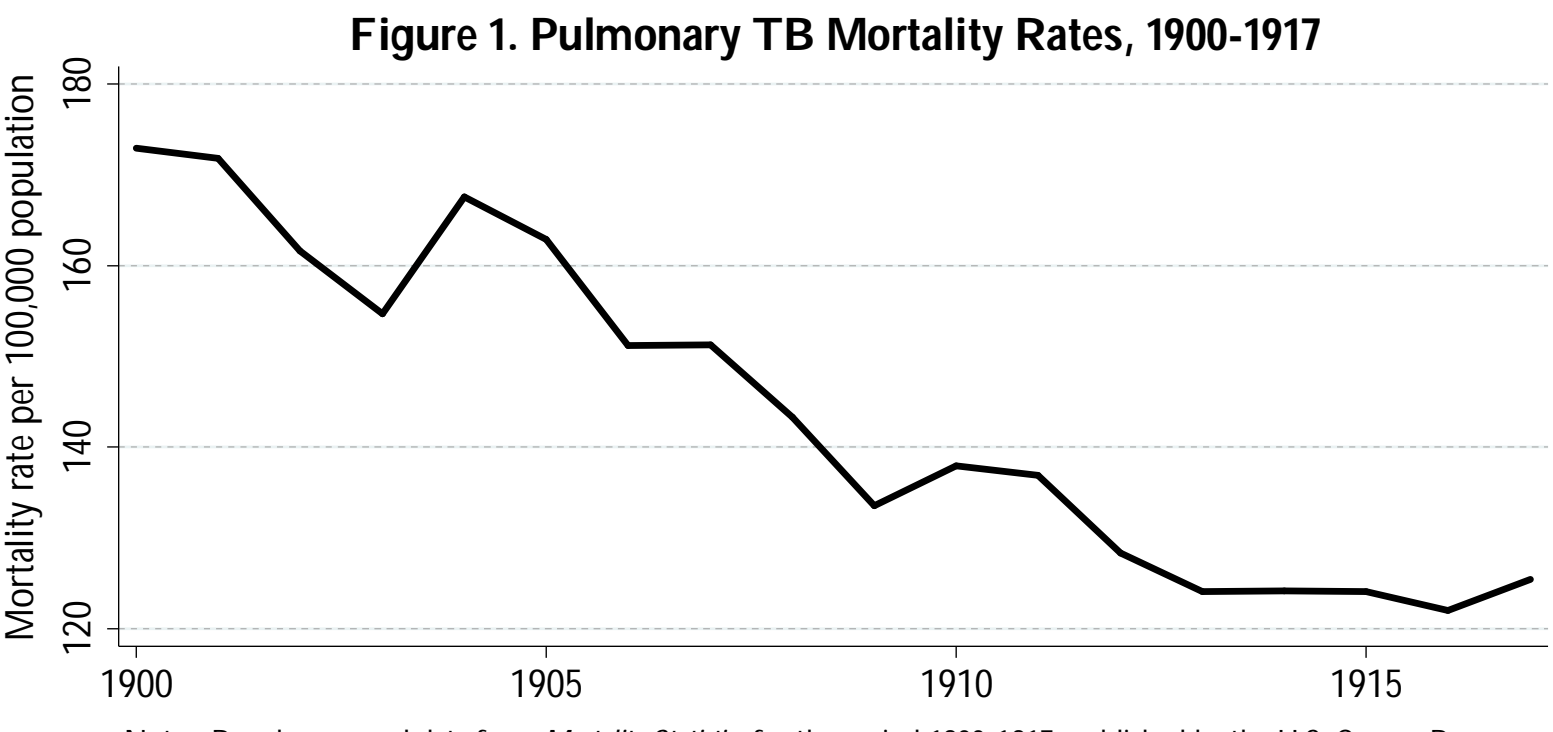

Notes: Based on annual data from Matality Statistics for the period 1900-1917, published by the U.S. Census Bureau. 


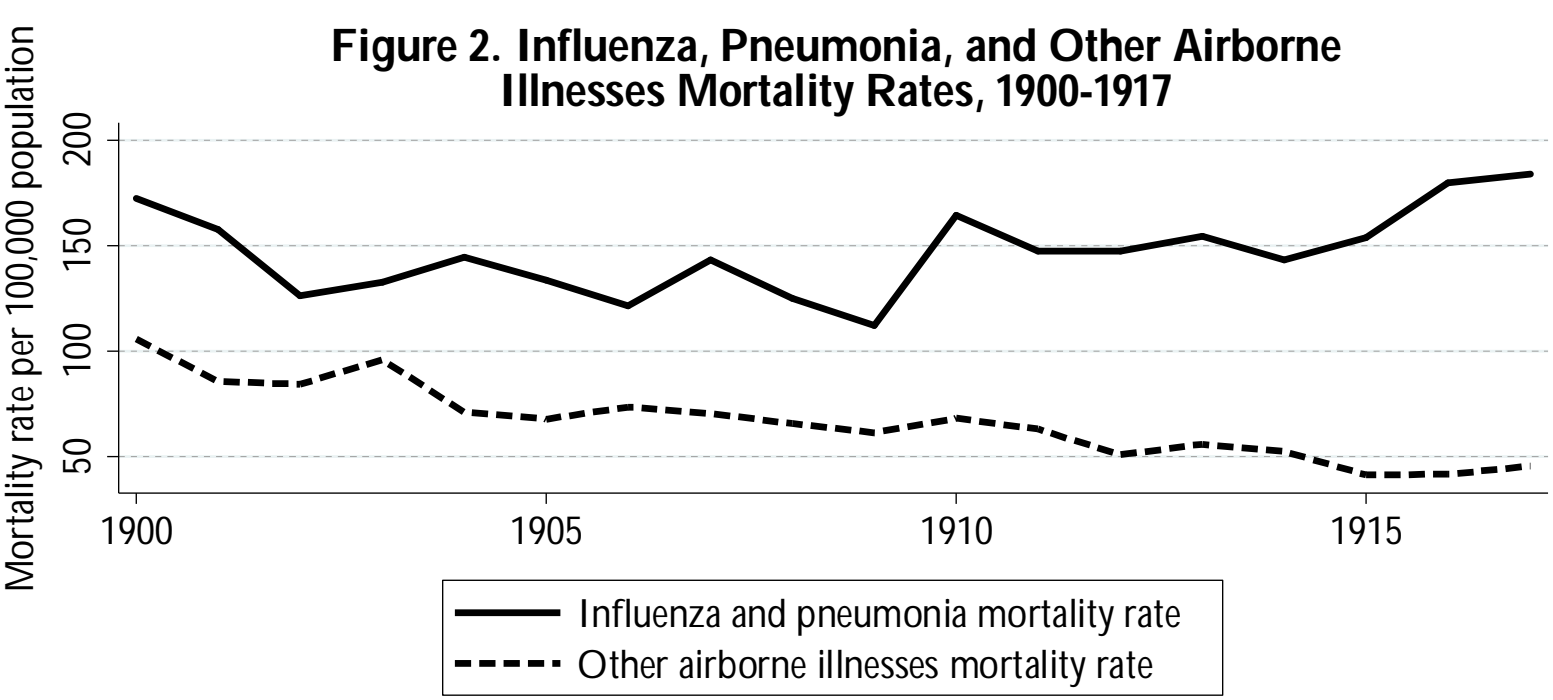

Notes: Based on annual data from Martality Statistics for the period 1900-1917, published by the U.S. Census Bureau. O ther airborne illnesses include measles, scarlet fever, whooping cough, and diphtheria/ croup. 
Figure 3. Actual vs. Predicted Pulmonary Tuberculosis Mortality Rates:

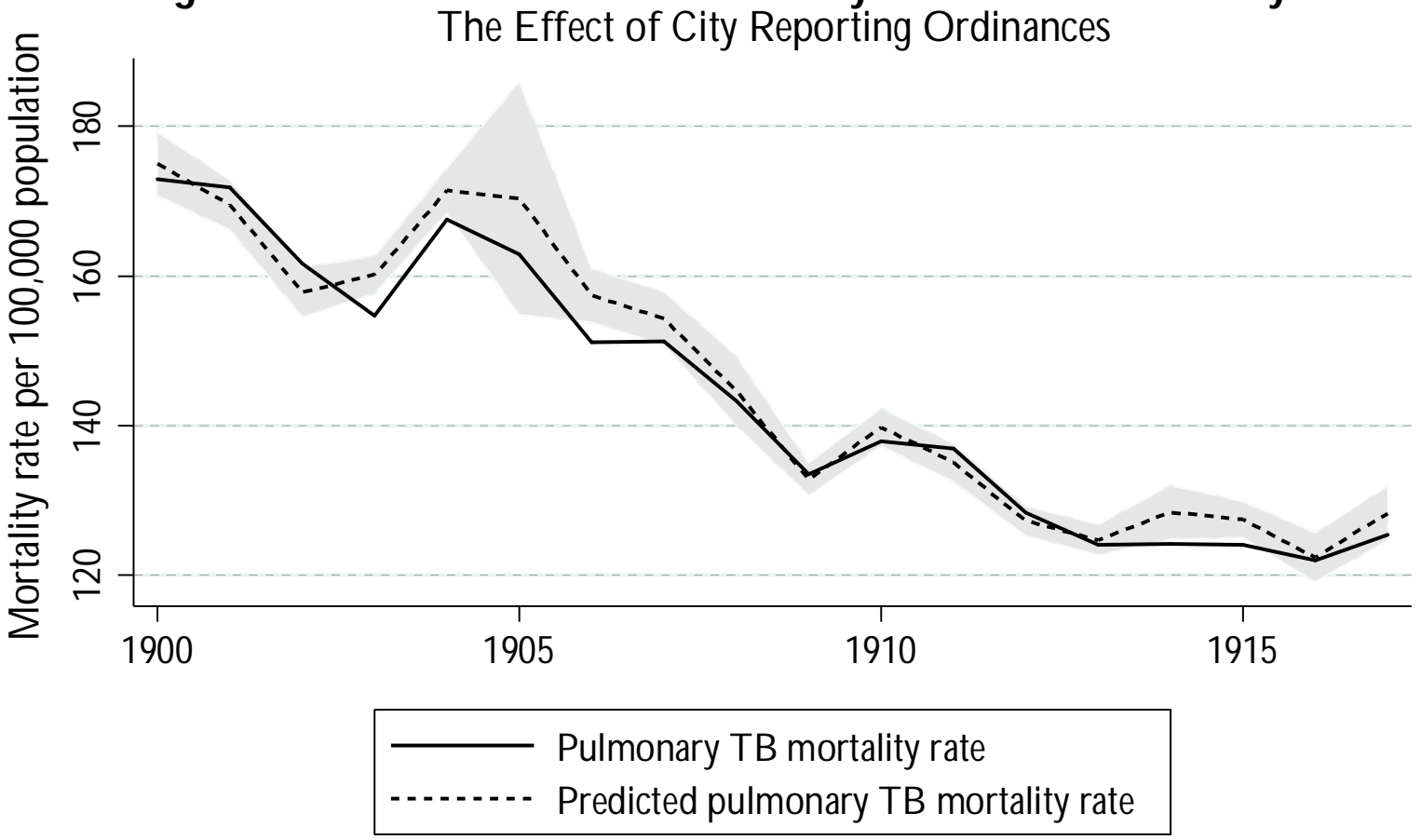

Notes: Based on annual data from MatalityStatistis for the period 1900-1917, published by the U.S. Census Bureau. Predicted pulmonary TB mortality rates are calculated under the assumption that city reporting ordinances were not implemented. Shaded area represents $90 \%$ confidence region around predicted pulmonary TB mortality rates. 


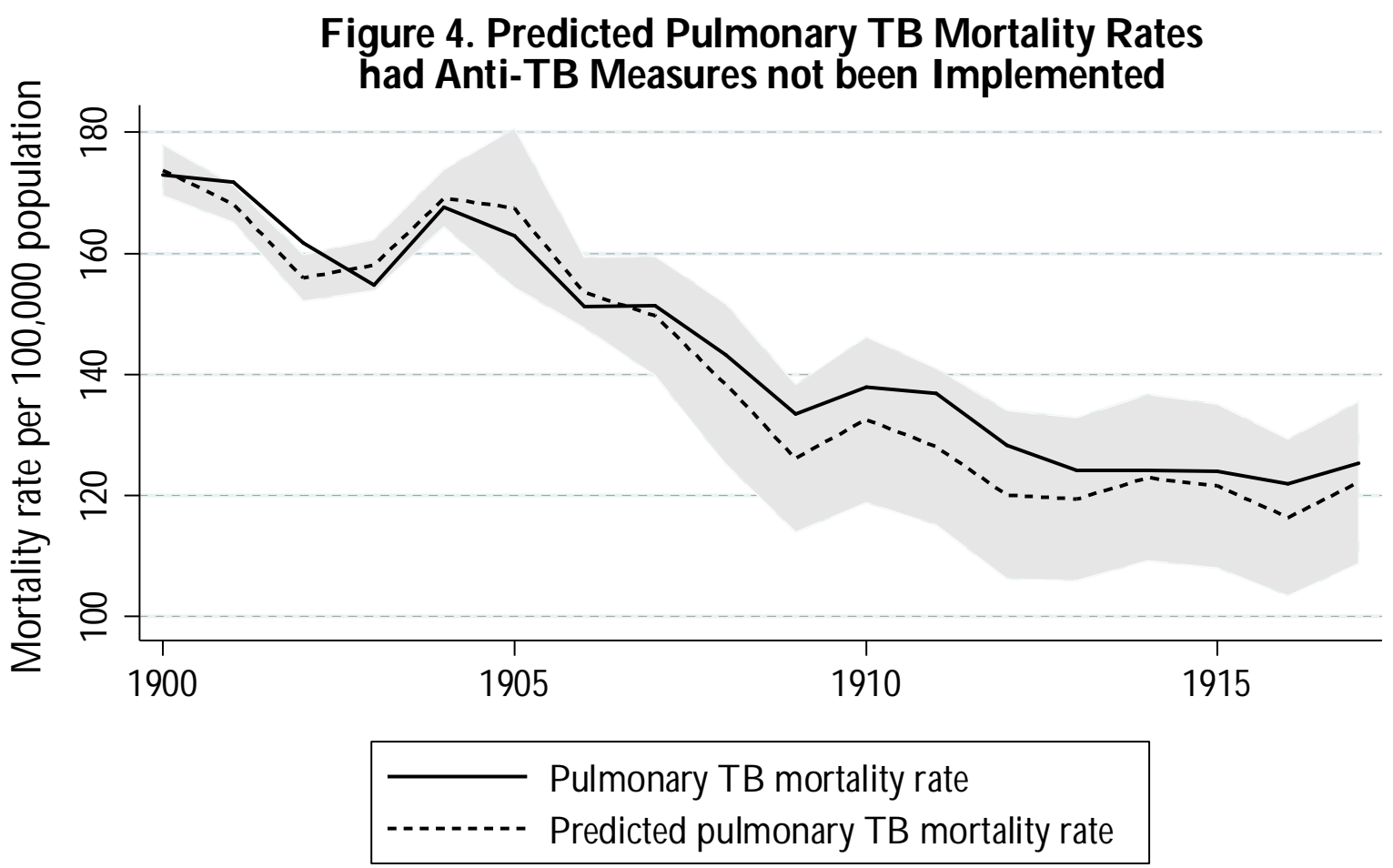

Notes: Based on annual data from MatalityStatisticsfor the period 1900-1917, published by the U.S. Census Bureau. Predicted pulmonary TB mortality rates are calculated under the assumption that none of the anti-TB measures listed in Table 1 were implemented. Shaded area represents $90 \%$ confidence region around predicted pulmonary TB mortality rates. 


\begin{tabular}{|c|c|c|}
\hline & $\begin{array}{l}\text { Mean } \\
\text { (SD) }\end{array}$ & D escription \\
\hline Pulmonary TB Matality & $\begin{array}{l}141.5 \\
(78.7)\end{array}$ & Pulmonary tuberculosis mortality per 100,000 population \\
\hline Sanatarium & $\begin{array}{l}.078 \\
.(268)\end{array}$ & $=1$ if municipality had a sanatorium, $=0$ otherwise \\
\hline TB Hospital & $\begin{array}{l}.087 \\
(.281)\end{array}$ & $=1$ if municipality had a TB hospital, $=0$ otherwise \\
\hline Open-Air Camp & $\begin{array}{l}.068 \\
(.251)\end{array}$ & $=1$ if municipality had an open-air camp, $=0$ otherwise \\
\hline RepatingOrdinance & $\begin{array}{l}.131 \\
(.338)\end{array}$ & $=1$ if municipality required reporting of TB cases, $=0$ otherwise \\
\hline StateReportingLaw & $\begin{array}{c}.510 \\
(.500)\end{array}$ & $=1$ if state required reporting of $\mathrm{TB}$ cases, $=0$ otherwise \\
\hline Disinfection Ordinance & $\begin{array}{l}.067 \\
(.249)\end{array}$ & $\begin{array}{l}=1 \text { if municipality required disinfection of premises after death or } \\
\text { removal of a TB patient, }=0 \text { otherwise }\end{array}$ \\
\hline StateDisinfetionLaw & $\begin{array}{l}.079 \\
(.269)\end{array}$ & $\begin{array}{l}=1 \text { if state required disinfection of premises after death or removal } \\
\text { of a TB patient, }=0 \text { otherwise }\end{array}$ \\
\hline SpittingOrdiname & $\begin{array}{l}.273 \\
(.446)\end{array}$ & $=1$ if municipality had an anti-spitting ordinance $=0$ otherwise \\
\hline Common Cup Ordinance & $\begin{array}{l}.018 \\
(.134)\end{array}$ & $=1$ if municipality had a common cup drinking ban, $=0$ otherwise \\
\hline StateCommon CupLaw & $\begin{array}{c}.110 \\
(.314)\end{array}$ & $=1$ if state had a common cup drinking ban, $=0$ otherwise \\
\hline Muniaipal TB Assoiation & $\begin{array}{l}.360 \\
(.480)\end{array}$ & $=1$ if municipality had a TB association, $=0$ otherwise \\
\hline StateTB Asscaiation & $\begin{array}{l}.697 \\
(.451)\end{array}$ & $=1$ if state had a TB association, $=0$ otherwise \\
\hline Dispensary & $\begin{array}{c}.261 \\
(.439)\end{array}$ & $=1$ if municipality had a TB dispensary, = 0 otherwise \\
\hline $\mathrm{N}$ & 7,439 & \\
\hline
\end{tabular}

Notes: Unweighted means with standard deviations in parentheses. 
Table 2. Pulmonary T B Mortality and Anti-T B Interventions, 1900-1917

\begin{tabular}{|c|c|c|c|c|}
\hline & (1) & (2) & (3) & (4) \\
\hline Sanatorium & $\begin{array}{l}-.017 \\
(.026)\end{array}$ & $\begin{array}{l}-.014 \\
(.025)\end{array}$ & $\begin{array}{l}-.016 \\
(.024)\end{array}$ & $\begin{array}{l}-.018 \\
(.024)\end{array}$ \\
\hline TB Hospital & $\begin{array}{c}.022 \\
(.029)\end{array}$ & $\begin{array}{c}.022 \\
(.028)\end{array}$ & $\begin{array}{c}.021 \\
(.029)\end{array}$ & $\begin{array}{c}.023 \\
(.028)\end{array}$ \\
\hline Open-Air Camp & $\begin{array}{l}-.021 \\
(.021)\end{array}$ & $\begin{array}{l}-.019 \\
(.019)\end{array}$ & $\begin{array}{l}-.017 \\
(.022)\end{array}$ & $\begin{array}{l}-.015 \\
(.020)\end{array}$ \\
\hline ReportingOrdinance & $\ldots$ & $\begin{array}{c}-.057 * * \\
(.026)\end{array}$ & $\begin{array}{c}-.061 * * \\
(.030)\end{array}$ & $\begin{array}{c}-.062^{* *} \\
(.028)\end{array}$ \\
\hline StateRepartingLaw & $\ldots$ & $\begin{array}{l}-.008 \\
(.014)\end{array}$ & $\begin{array}{l}-.007 \\
(.015)\end{array}$ & $\begin{array}{l}-.011 \\
(.016)\end{array}$ \\
\hline Disinfeetion Ordinance & $\ldots$ & $\begin{array}{l}.040 \\
(.030)\end{array}$ & $\begin{array}{c}.042 \\
(.032)\end{array}$ & $\begin{array}{c}.035 \\
(.032)\end{array}$ \\
\hline StateDisinfetion Law & $\ldots$ & $\begin{array}{c}-.020 \\
(.025)\end{array}$ & $\begin{array}{l}-.024 \\
(.028)\end{array}$ & $\begin{array}{l}-.021 \\
(.029)\end{array}$ \\
\hline SpittingOrdinance & $\ldots$ & $\ldots$ & $\begin{array}{c}.019 \\
(.026)\end{array}$ & $\begin{array}{c}.014 \\
(.023)\end{array}$ \\
\hline Common Cup Ordiname & $\ldots$ & $\ldots$ & $\begin{array}{c}.010 \\
(.021)\end{array}$ & $\begin{array}{c}.014 \\
(.021)\end{array}$ \\
\hline StateCommm CupLaw & $\ldots$ & $\ldots$ & $\begin{array}{l}-.021 \\
(.021)\end{array}$ & $\begin{array}{l}-.022 \\
(.022)\end{array}$ \\
\hline Muniaipal TBAssoiation & $\ldots$ & $\ldots$ & $\ldots$ & $\begin{array}{c}.005 \\
(.016)\end{array}$ \\
\hline StateTBAssociation & $\ldots$ & ... & ... & $\begin{array}{c}.023 \\
(.020)\end{array}$ \\
\hline Dispensary & ... & ... & ... & $\begin{array}{c}.019 \\
(.019)\end{array}$ \\
\hline $\begin{array}{l}\mathrm{N} \\
\mathrm{R}^{2}\end{array}$ & $\begin{array}{c}7,439 \\
.882\end{array}$ & $\begin{array}{c}7,439 \\
.882\end{array}$ & $\begin{array}{c}7,439 \\
.883\end{array}$ & $\begin{array}{c}7,439 \\
.883\end{array}$ \\
\hline
\end{tabular}

*Statistically significant at $10 \%$ level; $* *$ at $5 \%$ level; $* * *$ at $1 \%$ level.

Notes: Based on annual data from Matality Statisicsfor the period 1900-1917, published by the U.S. Census Bureau. Each column represents the results from a separate OLS regression. The dependent variable is equal to the natural log of the pulmonary tuberculosis mortality rate per 100,000 population in municipality mand year t. Controls include municipality fixed effects, year fixed effects, and municipality-specific linear trends. Regressions are weighted by municipality population. Standard errors, corrected for clustering at the state level, are in parentheses. 
Table 3. A Closer Look at Sanatoniums

\begin{tabular}{|c|c|c|c|c|c|}
\hline & $(1)$ & $(2)$ & (3) & $(4)$ & $(5)$ \\
\hline Sanatonium & $\ldots$ & $\cdots$ & $\begin{array}{l}-.014 \\
(.023)\end{array}$ & $\begin{array}{l}-.019 \\
(.024)\end{array}$ & $\begin{array}{l}-.019 \\
(.023)\end{array}$ \\
\hline Number of Sanataiumsin Muniapality & $\begin{array}{l}.018 \\
(.020)\end{array}$ & $\cdots$ & $\ldots$ & $\cdots$ & $\cdots$ \\
\hline $\begin{array}{l}\text { Number of SanatoriumBedsin } \\
\text { Muniaipality(100s of beds) }\end{array}$ & $\ldots$ & $\begin{array}{l}-.002 \\
(.003)\end{array}$ & $\cdots$ & $\cdots$ & $\ldots$ \\
\hline Any Sanatoniumin State & $\ldots$ & $\ldots$ & $\begin{array}{l}.002 \\
.017\end{array}$ & $\cdots$ & $\cdots$ \\
\hline Number of Sanatoriums in State & $\ldots$ & $\ldots$ & $\ldots$ & $\begin{array}{l}-.003 \\
(.005)\end{array}$ & $\cdots$ \\
\hline StateRun Sanatorium & .. & $\ldots$ & $\cdots$ & $\cdots$ & $\begin{array}{c}-.038 * * \\
(.016)\end{array}$ \\
\hline $\begin{array}{l}\mathrm{N} \\
\mathrm{R}^{2}\end{array}$ & $\begin{array}{c}7,439 \\
.883\end{array}$ & $\begin{array}{c}7,439 \\
.883\end{array}$ & $\begin{array}{c}7,439 \\
.883\end{array}$ & $\begin{array}{c}7,439 \\
.883\end{array}$ & $\begin{array}{c}7,439 \\
.883\end{array}$ \\
\hline
\end{tabular}

*Statistically significant at $10 \%$ level; ** at $5 \%$ level; *** at $1 \%$ level.

Notes: Based on annual data from Matality Statisticsfor the period 1900-1917, published by the U.S. Census Bureau. Each column represents the results from a separate OLS regression. The dependent variable is equal to the natural log of the pulmonary tuberculosis mortality rate per 100,000 population in municipality mand year $\mathrm{t}$. Controls include the covariates listed in Table 1, municipality fixed effects, year fixed effects, and municipality-specific linear trends. Regressions are weighted by municipality population. Standard errors, corrected for clustering at the state level, are in parentheses. 
Table 4. Pulmonary TB Mortality and Leads and Lags of Municipal Reporting Ordinances

\begin{tabular}{|c|c|c|c|c|}
\hline & (1) & (2) & (3) & (4) \\
\hline 3 Years Prior to RepartingOrdiname & $\ldots$ & $\ldots$ & $\ldots$ & $\begin{array}{l}.012 \\
(.021)\end{array}$ \\
\hline 2 Years Prior to RepatingOrdiname & ... & $\ldots$ & $\begin{array}{l}-.017 \\
(.020)\end{array}$ & $\begin{array}{l}-.011 \\
(.027)\end{array}$ \\
\hline 1 Yæar Prior to RepartingOrdinance & ... & $\begin{array}{c}-.033 \\
(.028)\end{array}$ & $\begin{array}{l}-.039 \\
(.034)\end{array}$ & $\begin{array}{l}-.034 \\
(.042)\end{array}$ \\
\hline Year 0 & $\begin{array}{c}-.067 * * \\
(.031)\end{array}$ & $\begin{array}{c}-.078^{* *} \\
(.037)\end{array}$ & $\begin{array}{l}-.085 * \\
(.043)\end{array}$ & $\begin{array}{r}-.079 \\
(.051)\end{array}$ \\
\hline 1 Yer After RepatingOrdinance & $\begin{array}{c}-.056^{* *} \\
(.027)\end{array}$ & $\begin{array}{c}-.068 * \\
(.034)\end{array}$ & $\begin{array}{l}-.075 * \\
(.041)\end{array}$ & $\begin{array}{r}-.069 \\
(.051)\end{array}$ \\
\hline 2 Yerrs After Repating Ordiname & $\begin{array}{c}-.060^{*} \\
(.030)\end{array}$ & $\begin{array}{r}-.074^{*} \\
(.037)\end{array}$ & $\begin{array}{l}-.082 * \\
(.043)\end{array}$ & $\begin{array}{r}-.075 \\
(.053)\end{array}$ \\
\hline 3+ Years After RepartingOrdinance & $\begin{array}{c}-.091 * * \\
(.037)\end{array}$ & $\begin{array}{c}-.108^{* *} \\
(.044)\end{array}$ & $\begin{array}{c}-.117 * * \\
(.051)\end{array}$ & $\begin{array}{r}-.109 * \\
(.062)\end{array}$ \\
\hline $\begin{array}{l}\text { Mean } \\
\mathrm{N} \\
\mathrm{R}^{2}\end{array}$ & $\begin{array}{c}141.5 \\
7,439 \\
.883\end{array}$ & $\begin{array}{c}141.5 \\
7,439 \\
.883\end{array}$ & $\begin{array}{c}141.5 \\
7,439 \\
.883\end{array}$ & $\begin{array}{c}141.5 \\
7,439 \\
.883\end{array}$ \\
\hline
\end{tabular}

*Statistically significant at $10 \%$ level; ** at $5 \%$ level; *** at $1 \%$ level.

Notes: Based on annual data from Matality Statisicsfor the period 1900-1917, published by the U.S. Census Bureau. Each column represents the results from a separate OLS regression. The dependent variable is equal to the natural log of the pulmonary tuberculosis mortality rate per 100,000 population in municipality mand year t. Controls include the covariates listed in Table 1, municipality fixed effects, year fixed effects, and municipality-specific linear trends.

Regressions are weighted by municipality population. Standard errors, corrected for clustering at the state level, are in parentheses. 
Table 5. Extensions and Robustness of Municipal Reporting Ordinances

\begin{tabular}{|c|c|c|c|c|c|c|}
\hline & (1) & (2) & (3) & (4) & (5) & (6) \\
\hline & $\begin{array}{l}\text { Control for } \\
\text { typhoid } \\
\text { mortality }\end{array}$ & $\begin{array}{l}\text { Cities with } \\
\text { population } \\
>50,000\end{array}$ & $\begin{array}{l}\text { D ensely } \\
\text { populated } \\
\text { cities with } \\
\text { population } \\
>50,000\end{array}$ & $\begin{array}{l}\text { Cities with } 18 \\
\text { years of data }\end{array}$ & $\begin{array}{c}\text { D ependent } \\
\text { variable: } \\
\text { (Non-pulmmary } \\
\text { TBMortality) })^{1 / 4}\end{array}$ & $\begin{array}{l}\text { D ependent } \\
\text { variable: } \\
\text { (PulmanaryTB } \\
\text { Motality) } \\
\end{array}$ \\
\hline RepatingOrdinance & $\begin{array}{c}-.049^{*} \\
(.026)\end{array}$ & $\begin{array}{c}.067 * * \\
(.031)\end{array}$ & $\begin{array}{c}.075^{*} \\
(.042)\end{array}$ & $\begin{array}{c}-.071 * * \\
(.029)\end{array}$ & $\begin{array}{l}.019 \\
(.021) \\
{[.639]}\end{array}$ & $\begin{array}{c}.056^{* *} \\
(.025) \\
{[-9.11]}\end{array}$ \\
\hline $\begin{array}{l}\text { Mean of TB Mortality } \\
N \\
\mathrm{R}^{2}\end{array}$ & $\begin{array}{c}141.5 \\
7,439 \\
.885 \\
\end{array}$ & $\begin{array}{c}162.0 \\
1,693 \\
.924 \\
\end{array}$ & $\begin{array}{c}164.6 \\
931 \\
.915 \\
\end{array}$ & $\begin{array}{c}143.9 \\
5,254 \\
.884\end{array}$ & $\begin{array}{c}17.6 \\
7,439 \\
.608 \\
\end{array}$ & $\begin{array}{c}141.5 \\
7,439 \\
.889 \\
\end{array}$ \\
\hline
\end{tabular}

*Statistically significant at $10 \%$ level; ${ }^{* *}$ at $5 \%$ level; ${ }^{* * *}$ at $1 \%$ level.

Notes: Based on annual data from Matality Statisicsfor the period 1900-1917, published by the U.S. Census Bureau. Each column represents the results from a separate OLS regression. Columns (1)-(4): The dependent variable is equal to the natural log of the pulmonary tuberculosis mortality rate per 100,000 population in municipality mand year $\mathrm{t}$ Columns (5)-(6): The dependent variable is equal to the quartic root of the specified

mortality rate per 100,000 population in municipality mand year t; marginal effects are in brackets. Controls include the covariates listed in Table 1, municipality fixed effects, year fixed effects, and municipality-specific linear trends. Regressions are weighted by municipality population. Standard errors, corrected for clustering at the state level, are in parentheses. 
Table 6. Extensions and Robustness of State-Run Sanatoriums

(1)

\begin{tabular}{|c|c|c|c|c|c|c|}
\hline & $\begin{array}{l}\text { Control } \\
\text { for typhoid } \\
\text { mortality }\end{array}$ & $\begin{array}{l}\text { Cities with } \\
\text { population } \\
>50,000\end{array}$ & $\begin{array}{l}\text { D ensely } \\
\text { populated } \\
\text { cities with } \\
\text { population } \\
>50,000\end{array}$ & $\begin{array}{l}\text { Cities with } 18 \\
\text { years of data }\end{array}$ & $\begin{array}{l}\text { D ependent } \\
\text { variable: } \\
\text { (Non-pulmanary } \\
\text { TBMotality) }{ }^{1 / 4}\end{array}$ & $\begin{array}{l}\text { D ependent } \\
\text { variable: } \\
\text { (Pulmarnary TB } \\
\text { Matality) } \\
\end{array}$ \\
\hline StateRun Sanatarium & $\begin{array}{c}.034^{* *} \\
(.014)\end{array}$ & $\begin{array}{c}-.043^{* *} \\
(.019)\end{array}$ & $\begin{array}{c}-.044 \\
(.026)\end{array}$ & $\begin{array}{c}-.034^{* *} \\
(.015)\end{array}$ & $\begin{array}{l}.011 \\
(.019) \\
{[.391]}\end{array}$ & $\begin{array}{c}.032^{* *} \\
(.015) \\
{[-5.27]}\end{array}$ \\
\hline $\begin{array}{l}\text { Mean of TB Mortality } \\
N \\
\mathrm{R}^{2}\end{array}$ & $\begin{array}{c}141.5 \\
7,439 \\
.886\end{array}$ & $\begin{array}{c}162.0 \\
1,693 \\
.925\end{array}$ & $\begin{array}{c}164.6 \\
931 \\
.916\end{array}$ & $\begin{array}{c}143.9 \\
5,254 \\
.884\end{array}$ & $\begin{array}{c}17.6 \\
7,439 \\
.608\end{array}$ & $\begin{array}{c}141.5 \\
7,439 \\
.890\end{array}$ \\
\hline
\end{tabular}

*Statistically significant at $10 \%$ level; ${ }^{* *}$ at $5 \%$ level; *** at $1 \%$ level.

Notes: Based on annual data from Matality Statisicsfor the period 1900-1917, published by the U.S. Census Bureau. Each column represents the results from a separate OLS regression. Columns (1)-(4): The dependent variable is equal to the natural log of the pulmonary tuberculosis mortality rate per 100,000 population in municipality mand year t Columns (5)-(6): The dependent variable is equal to the quartic root of the specified

mortality rate per 100,000 population in municipality mand year t; marginal effects are in brackets. Controls include the covariates listed in Table 1 , municipality fixed effects, year fixed effects, and municipality-specific linear trends. Regressions are weighted by municipality population. Standard errors, corrected for clustering at the state level, are in parentheses. 


\section{Table 7. Did Anti-Spitting Ordinances, Common Cup Bans, or T B Associations have Spillover Effects on other Airbome Illnesses?}
(1)
$(2)$
(3)
(4)

\begin{tabular}{|c|c|c|c|c|}
\hline & $\begin{array}{c}\text { Fluand Pnemmia } \\
\text { Motality }\end{array}$ & $\begin{array}{c}\text { Flu and Pnemmia } \\
\text { Matality }\end{array}$ & $\begin{array}{l}\text { Other Airbame } \\
\text { Illnesses Mortality }\end{array}$ & $\begin{array}{l}\text { Other Airbame } \\
\text { Illnesses Matality }\end{array}$ \\
\hline SpittingOrdinance & $\begin{array}{c}-.046 \\
(.030) \\
{[-7.78]}\end{array}$ & $\begin{array}{c}.050^{*} \\
(.026) \\
{[-8.56]}\end{array}$ & $\begin{array}{c}-.019 \\
(.043) \\
{[-1.49]}\end{array}$ & $\begin{array}{l}-.017 \\
(.044) \\
{[-1.29]}\end{array}$ \\
\hline Common CupOrdinance & $\begin{array}{l}.020 \\
(.103) \\
{[3.41]}\end{array}$ & $\begin{array}{l}.046 \\
(.069) \\
{[7.76]}\end{array}$ & $\begin{array}{c}-.041 \\
(.033) \\
{[-3.20]}\end{array}$ & $\begin{array}{c}-.016 \\
(.044) \\
{[-1.24]}\end{array}$ \\
\hline StateCommm CupLan & $\begin{array}{l}.060 \\
(.043) \\
{[10.1]}\end{array}$ & $\begin{array}{l}.064 \\
(.039) \\
{[10.8]}\end{array}$ & $\begin{array}{l}-.029 \\
(.044) \\
{[-2.23]}\end{array}$ & $\begin{array}{l}-.032 \\
(.047) \\
{[-2.45]}\end{array}$ \\
\hline Muriajpal TBAssociation & $\begin{array}{c}-.021 \\
(.025) \\
{[-3.62]}\end{array}$ & $\begin{array}{c}-.027 \\
(.028) \\
{[-4.64]}\end{array}$ & $\begin{array}{l}.008 \\
(.021) \\
{[.639]}\end{array}$ & $\begin{array}{l}.015 \\
(.023) \\
{[1.19]}\end{array}$ \\
\hline StateTBAssciatior. & $\begin{array}{l}.004 \\
(.039) \\
{[.743]}\end{array}$ & $\begin{array}{l}.011 \\
(.037) \\
{[1.83]}\end{array}$ & $\begin{array}{l}.053 * * \\
(.024) \\
{[4.12]}\end{array}$ & $\begin{array}{l}.043 \\
(.026) \\
{[3.34]}\end{array}$ \\
\hline $\begin{array}{l}\text { Mean of Mortality Rate } \\
\mathrm{N} \\
\mathrm{R}^{2} \\
\text { Other Anti-TB Measures? }\end{array}$ & $\begin{array}{l}148.1 \\
7,439 \\
.739 \\
\text { No }\end{array}$ & $\begin{array}{l}148.1 \\
7,439 \\
.743 \\
\text { Yes }\end{array}$ & $\begin{array}{c}51.9 \\
7,439 \\
.567 \\
\text { No }\end{array}$ & $\begin{array}{c}51.9 \\
7,439 \\
.568 \\
\text { Yes }\end{array}$ \\
\hline
\end{tabular}

*Statistically significant at $10 \%$ level; ** at $5 \%$ level; *** at $1 \%$ level.

Notes: Based on annual data from Matality Statisticsfor the period 1900-1917, published by the U.S. Census Bureau. Each column represents the results from a separate OLS regression. Columns (1)-(2): The dependent variable is equal to the quartic root of the influenza and pneumonia mortality rate per 100,000 population in municipality mand year t; marginal effects are in brackets. Columns (3)-(4): The dependent variable is equal to the quartic root of the measles, scarlet fever, whooping cough, and diphtheria/ croup mortality rate per 100,000 population in municipality mand year t; marginal effects are in brackets. Controls include municipality fixed effects, year fixed effects, and municipality-specific linear trends. Regressions are weighted by municipality population. Standard errors, corrected for clustering at the state level, are in parentheses. 
Appendix Table 1. Municipal-level Anti-TB Measures, 1900-1917

\begin{tabular}{|c|c|c|c|c|c|c|c|c|c|c|c|}
\hline State & City & Y ears of available data & $\begin{array}{c}\text { First } \\
\text { sanatorium }\end{array}$ & $\begin{array}{l}\text { First TB } \\
\text { hospital }\end{array}$ & $\begin{array}{l}\text { First } \\
\text { open-air } \\
\text { camp }\end{array}$ & $\begin{array}{l}\text { Municipal } \\
\text { reporting } \\
\text { ordinance }\end{array}$ & $\begin{array}{c}\text { Municipal } \\
\text { disinfection } \\
\text { ordinance }\end{array}$ & $\begin{array}{l}\text { Municipal } \\
\text { spitting } \\
\text { ordinance }\end{array}$ & $\begin{array}{l}\text { Municipal } \\
\text { common } \\
\text { cup } \\
\text { ordinance }\end{array}$ & $\begin{array}{c}\text { Municipal } \\
\text { TB } \\
\text { association }\end{array}$ & $\begin{array}{c}\text { First } \\
\text { dispensary }\end{array}$ \\
\hline$\overline{\mathrm{AL}}$ & Birmingham & $1908-1917$ & 1910 & & & & & & & 1910 & 1911 \\
\hline $\mathrm{AL}$ & Mobile & $1900-1917$ & & & & & & & & & 1914 \\
\hline $\mathrm{AL}$ & Montgomery & 1908-1917 & & & 1911 & & & & 1911 & & 1909 \\
\hline $\mathrm{CA}$ & Alameda & $1900-1917$ & & & & & & & & 1909 & \\
\hline $\mathrm{CA}$ & Bakersfield & $1910-1917$ & & & & & & & & 1917 & \\
\hline $\mathrm{CA}$ & Berkeley & $1906-1917$ & & & & & & & & & 1910 \\
\hline $\mathrm{CA}$ & Eureka & $1910-1917$ & & & & & & & & 1911 & \\
\hline CA & Fresno & $1900-1917$ & 1915 & & & & & 1911 & & 1914 & 1916 \\
\hline $\mathrm{CA}$ & Los Angeles & $1900-1917$ & 1902 & & & & & & & 1908 & 1906 \\
\hline $\mathrm{CA}$ & Oakland & $1900-1917$ & & & & & & 1903 & & 1909 & 1910 \\
\hline CA & Pasadena & $1906-1917$ & 1909 & & & 1912 & & 1910 & & 1909 & 1915 \\
\hline $\mathrm{CA}$ & Sacramento & $1900-1917$ & & 1916 & & & & 1904 & & 1908 & 1915 \\
\hline CA & San Bernardino & 1910-1917 & & & & & & & & 1917 & \\
\hline CA & San Diego & $1900-1917$ & & 1903 & 1912 & & & 1907 & & 1910 & 1909 \\
\hline $\mathrm{CA}$ & San Francisco & $1900-1917$ & 1909 & & & 1903 & & & 1913 & 1908 & 1909 \\
\hline $\mathrm{CA}$ & San Jose & $1900-1917$ & & 1911 & & & & 1907 & & 1909 & 1911 \\
\hline CA & Stockton & 1906-1917 & & & 1909 & & & & & 1912 & 1915 \\
\hline $\mathrm{CO}$ & Colorado Springs & $1906-1917$ & & & & 1908 & 1909 & 1907 & 1912 & 1910 & \\
\hline $\mathrm{CO}$ & D enver & $1900-1917$ & & & & & & 1905 & & 1917 & 1913 \\
\hline $\mathrm{CO}$ & Pueblo & $1900-1917$ & & & & & & 1905 & & & 1910 \\
\hline $\mathrm{CT}$ & Bridgeport & $1900-1917$ & & 1917 & 1907 & 1902 & 1902 & & & 1914 & \\
\hline $\mathrm{CT}$ & Bristol & $1900-1917$ & & & & & & & & 1917 & 1916 \\
\hline $\mathrm{CT}$ & Greenwich & $1900-1917$ & & & 1912 & & & & & & \\
\hline $\mathrm{CT}$ & Hartford & $1900-1917$ & 1902 & & & & & 1906 & & 1905 & 1908 \\
\hline $\mathrm{CT}$ & Meriden & $1900-1917$ & 1910 & & & 1910 & 1910 & 1903 & 1910 & 1907 & \\
\hline CT & Middletown & $1900-1917$ & & & & & & & & 1909 & \\
\hline $\mathrm{CT}$ & New Britain & $1900-1917$ & & & & 1905 & & & & 1908 & \\
\hline $\mathrm{CT}$ & New Haven & $1900-1917$ & & 1916 & 1910 & 1905 & & 1901 & & 1902 & 1907 \\
\hline CT & New London & $1900-1917$ & & & & & & & & 1912 & \\
\hline $\mathrm{CT}$ & Norwalk & $1900-1917$ & & & & & & & & 1909 & 1909 \\
\hline $\mathrm{CT}$ & Norwich & $1900-1917$ & 1913 & & & 1905 & & & & 1912 & \\
\hline $\mathrm{CT}$ & Stamford & $1900-1917$ & & & 1910 & & & 1910 & & 1910 & \\
\hline $\mathrm{CT}$ & Wallingford & $1900-1917$ & 1904 & & & & & & & 1915 & \\
\hline $\mathrm{CT}$ & Waterbury & $1900-1917$ & & & & & & & & 1908 & 1908 \\
\hline DE & Wilmington & $1900-1917$ & & & & 1908 & & 1907 & & 1909 & 1906 \\
\hline $\mathrm{DC}$ & Washington & $1900-1917$ & & 1908 & 1908 & 1908 & & 1903 & & 1902 & 1905 \\
\hline
\end{tabular}


Appendix Table 1. Municipal-level Anti-TB Measures, 1900-1917 (continued)

\begin{tabular}{|c|c|c|c|c|c|c|c|c|c|c|c|}
\hline State & City & Y ears of available data & $\begin{array}{c}\text { First } \\
\text { sanatorium }\end{array}$ & $\begin{array}{l}\text { First TB } \\
\text { hospital }\end{array}$ & $\begin{array}{l}\text { First } \\
\text { open-air } \\
\text { camp }\end{array}$ & $\begin{array}{l}\text { Municipal } \\
\text { reporting } \\
\text { ordinance }\end{array}$ & $\begin{array}{c}\text { Municipal } \\
\text { disinfection } \\
\text { ordinance }\end{array}$ & $\begin{array}{l}\text { Municipal } \\
\text { spitting } \\
\text { ordinance }\end{array}$ & $\begin{array}{l}\text { Municipal } \\
\text { common } \\
\text { cup } \\
\text { ordinance }\end{array}$ & $\begin{array}{c}\text { Municipal } \\
\text { TB } \\
\text { association }\end{array}$ & $\begin{array}{c}\text { First } \\
\text { dispensary }\end{array}$ \\
\hline FL & Jacksonville & $1900-1917$ & & 1913 & & & & 1908 & & & \\
\hline FL & Tampa & 1915-1917 & & & 1916 & & & & & & \\
\hline GA & Atlanta & 1900-1917 & 1909 & & & & & & & 1907 & 1907 \\
\hline GA & Savannah & 1900-1917 & & & & 1909 & & 1904 & & 1909 & \\
\hline IL & Aurora & 1900-1917 & & & & & & & & 1911 & 1917 \\
\hline IL & Chicago & 1900-1917 & 1915 & 1909 & 1910 & 1906 & 1907 & 1901 & 1913 & 1906 & 1907 \\
\hline IL & Decatur & 1900-1917 & & & & & & 1902 & & 1917 & \\
\hline IL & Evanston & 1908-1917 & & & & 1915 & & & & 1910 & \\
\hline IL & Jacksonville & 1900-1917 & & & & & & & & 1905 & 1912 \\
\hline IL & Ottawa & 1900-1909 & & & 1904 & & & & & & \\
\hline IL & Quincy & 1900-1917 & & & & & & 1914 & & & \\
\hline IL & Springfield & 1900-1917 & & & 1913 & & & 1907 & & 1910 & 1911 \\
\hline IN & Anderson & 1901-1917 & & & & & & & & 1912 & \\
\hline IN & Elkhart & 1901-1917 & & & & & & & & 1913 & \\
\hline IN & Evansville & 1900-1917 & & 1910 & & & & 1902 & & 1904 & 1908 \\
\hline IN & Fort Wayne & 1901-1917 & & & & & & 1904 & & 1910 & 1913 \\
\hline IN & Gary & 1910-1917 & & & & & & & & 1913 & \\
\hline IN & Huntington & 1901-1917 & & & & & & & & 1912 & \\
\hline IN & Indianapolis & 1900-1917 & & & 1904 & & 1902 & & & 1911 & 1908 \\
\hline IN & Kokomo & 1901-1917 & & & & & & & & 1912 & \\
\hline IN & Lafayette & 1900-1917 & & & 1915 & & & & & 1908 & \\
\hline IN & Laporte & 1910-1917 & & & & & & & & 1914 & \\
\hline IN & Logansport & 1901-1917 & & & & & & & & 1912 & \\
\hline IN & Muncie & 1900-1917 & & & & & & & & 1909 & \\
\hline IN & New Albany & 1901-1917 & & & & & & & & 1912 & 1915 \\
\hline IN & Peru & $1900-1917$ & & & & & & & & 1913 & \\
\hline IN & Richmond & 1900-1917 & & & & & & & & 1907 & \\
\hline IN & South Bend & 1901-1917 & 1914 & & 1909 & 1902 & & 1906 & & 1908 & 1908 \\
\hline IN & Terre Haute & $1900-1917$ & & & & & & & & 1909 & \\
\hline IA & Sioux City & 1900-1905 & & & & & & 1905 & & & \\
\hline KS & Kansas City & 1908-1917 & & & & & & & & 1913 & \\
\hline KS & Topeka & 1912-1917 & 1916 & & & & & & & & \\
\hline KS & Wichita & 1900-1917 & 1917 & & & & & & & & \\
\hline KY & Covington & 1900-1917 & & & & & & & & & 1912 \\
\hline KY & Frankfort & 1911-1917 & & & & & & & & 1912 & \\
\hline KY & Henderson & 1911-1917 & 1917 & & & & & & & & \\
\hline
\end{tabular}


Appendix Table 1. Municipal-level Anti-TB Measures, 1900-1917 (continued)

\begin{tabular}{|c|c|c|c|c|c|c|c|c|c|c|c|}
\hline State & City & Y ears of available data & $\begin{array}{c}\text { First } \\
\text { sanatorium }\end{array}$ & $\begin{array}{l}\text { First TB } \\
\text { hospital }\end{array}$ & $\begin{array}{c}\text { First } \\
\text { open-air } \\
\text { camp }\end{array}$ & $\begin{array}{l}\text { Municipal } \\
\text { reporting } \\
\text { ordinance }\end{array}$ & $\begin{array}{c}\text { Municipal } \\
\text { disinfection } \\
\text { ordinance }\end{array}$ & $\begin{array}{l}\text { Municipal } \\
\text { spitting } \\
\text { ordinance }\end{array}$ & $\begin{array}{l}\text { Municipal } \\
\text { common } \\
\text { cup } \\
\text { ordinance }\end{array}$ & $\begin{array}{c}\text { Municipal } \\
\text { TB } \\
\text { association }\end{array}$ & $\begin{array}{c}\text { First } \\
\text { dispensary } \\
\end{array}$ \\
\hline KY & Lexington & 1911-1917 & 1917 & & & & & & & & \\
\hline KY & Louisville & $1900-1917$ & 1907 & & & & & 1905 & & 1905 & 1907 \\
\hline KY & Newport & 1900-1917 & & & & & & & & 1916 & \\
\hline KY & Owensboro & 1911-1917 & & & & & & & & & 1915 \\
\hline $\mathrm{KY}$ & Paducah & $1900-1917$ & & & & & & & & 1910 & \\
\hline LA & New Orleans & 1900-1917 & & & 1908 & & 1912 & & & 1906 & 1908 \\
\hline ME & Auburn & 1906-1917 & & & & & & & & 1910 & \\
\hline ME & Augusta & 1900-1917 & & & & & & & & & 1913 \\
\hline $\mathrm{ME}$ & Bangor & 1900-1917 & & & 1910 & & & & & 1909 & 1909 \\
\hline ME & Lewiston & 1906-1917 & & & & & & 1912 & & 1910 & 1914 \\
\hline ME & Portland & 1900-1917 & & & & & 1909 & & & & 1910 \\
\hline ME & Waterville & 1906-1917 & & & & & & & & 1910 & 1910 \\
\hline MD & Annapolis & $1900-1909$ & & & & & & & & 1906 & \\
\hline MD & Baltimore & 1900-1917 & & & & & & 1905 & & & \\
\hline MD & Cumberland & 1906-1917 & 1913 & & & & & & & 1909 & 1913 \\
\hline MD & Frederick & $1900-1917$ & & & & & & & & 1907 & 1911 \\
\hline MD & Hagerstown & 1907-1917 & & & & & & & & 1911 & \\
\hline MA & Adams & $1900-1917$ & & & 1910 & & & & & 1908 & 1915 \\
\hline MA & Attleborough & 1900-1917 & & & & & & & & 1911 & 1915 \\
\hline MA & Beverly & $1900-1917$ & & & & & & & & 1915 & 1915 \\
\hline MA & Boston & $1900-1917$ & 1904 & & 1909 & & & & & 1903 & \\
\hline MA & Brockton & 1900-1917 & & & & & & 1904 & & 1904 & 1909 \\
\hline MA & Brookline & $1900-1917$ & & 1905 & 1908 & & & 1907 & & 1907 & 1912 \\
\hline MA & Cambridge & 1900-1917 & & & & & 1904 & & & 1903 & 1905 \\
\hline MA & Chelsea & 1900-1917 & & & & & & 1902 & & 1907 & 1910 \\
\hline MA & Chicopee & $1900-1917$ & & & & & & & & & 1915 \\
\hline MA & Clinton & 1900-1917 & 1915 & & 1909 & & & & & 1908 & 1916 \\
\hline MA & Everett & $1900-1917$ & & & & 1911 & & 1906 & 1911 & 1908 & 1915 \\
\hline MA & Fall River & $1900-1917$ & & 1907 & & 1906 & 1906 & 1901 & & 1908 & 1913 \\
\hline MA & Fitchburg & 1900-1917 & & 1913 & & & & & & 1907 & 1909 \\
\hline MA & Framingham & $1900-1917$ & & & & & & & & 1909 & 1915 \\
\hline MA & Gardner & $1900-1917$ & & & & & & & & 1908 & 1909 \\
\hline MA & Gloucester & 1900-1917 & & & & 1909 & & 1909 & & 1914 & 1915 \\
\hline MA & Haverhill & $1900-1917$ & 1913 & & & 1906 & & 1902 & & 1907 & 1908 \\
\hline MA & Holyoke & 1900-1917 & 1912 & & 1908 & & & 1903 & & 1907 & 1915 \\
\hline MA & Lawrence & $1900-1917$ & & 1910 & 1908 & & & & & 1907 & 1910 \\
\hline
\end{tabular}


Appendix Table 1. Municipal-level Anti-TB Measures, 1900-1917 (continued)

\begin{tabular}{|c|c|c|c|c|c|c|c|c|c|c|c|}
\hline State & City & Y ears of available data & $\begin{array}{c}\text { First } \\
\text { sanatorium }\end{array}$ & $\begin{array}{l}\text { First TB } \\
\text { hospital }\end{array}$ & $\begin{array}{l}\text { First } \\
\text { open-air } \\
\text { camp }\end{array}$ & $\begin{array}{l}\text { Municipal } \\
\text { reporting } \\
\text { ordinance }\end{array}$ & $\begin{array}{c}\text { Municipal } \\
\text { disinfection } \\
\text { ordinance }\end{array}$ & $\begin{array}{l}\text { Municipal } \\
\text { spitting } \\
\text { ordinance }\end{array}$ & $\begin{array}{l}\text { Municipal } \\
\text { common } \\
\text { cup } \\
\text { ordinance }\end{array}$ & $\begin{array}{c}\text { Municipal } \\
\text { TB } \\
\text { association }\end{array}$ & $\begin{array}{c}\text { First } \\
\text { dispensary }\end{array}$ \\
\hline MA & Leominster & $1900-1917$ & & & & & & & & & 1915 \\
\hline MA & Lowell & $1900-1917$ & & & 1906 & 1903 & 1913 & 1903 & & 1915 & 1915 \\
\hline MA & Lynn & $1900-1917$ & & 1912 & 1909 & 1906 & 1906 & 1906 & & 1907 & 1907 \\
\hline MA & Malden & 1900-1917 & & & & & & & & 1907 & 1908 \\
\hline MA & Medford & $1900-1917$ & & & & & & & & 1907 & 1915 \\
\hline MA & Melrose & $1900-1917$ & & & & & & & & 1909 & 1915 \\
\hline MA & New Bedford & 1900-1917 & 1908 & & & & & & & 1906 & 1909 \\
\hline MA & Newburyport & $1900-1917$ & & & & & & & & 1909 & 1909 \\
\hline MA & Newton & 1900-1917 & & & & & 1914 & & & & \\
\hline MA & North Adams & $1900-1917$ & & & & & & & & & 1914 \\
\hline MA & Northampton & $1900-1917$ & 1914 & & & & & & & 1907 & 1915 \\
\hline MA & Peabody & $1900-1917$ & & & & & & & & & 1914 \\
\hline MA & Pittsfield & $1900-1917$ & 1906 & 1913 & & & & & & 1905 & 1908 \\
\hline MA & Plymouth & $1900-1917$ & & & & & & & & & 1916 \\
\hline MA & Quincy & 1900-1917 & & & 1910 & & & & & 1908 & 1915 \\
\hline MA & Salem & $1900-1917$ & & 1907 & 1908 & & & 1908 & & 1907 & 1908 \\
\hline MA & Somerville & $1900-1917$ & & & & 1904 & & 1904 & & 1906 & 1911 \\
\hline MA & Springfield & $1900-1917$ & & 1912 & 1908 & 1904 & 1909 & 1901 & & 1904 & 1907 \\
\hline MA & Taunton & $1900-1917$ & & & & & & & & 1908 & 1915 \\
\hline MA & Wakefield & $1900-1917$ & & & & & & & & & 1915 \\
\hline MA & Waltham & $1900-1917$ & & 1911 & & & & 1906 & & 1908 & 1911 \\
\hline MA & Webster & $1900-1917$ & & & & & & & & & 1915 \\
\hline MA & Westfield & $1900-1917$ & 1910 & & & & & & & & 1910 \\
\hline MA & Winthrop & $1910-1917$ & & & & & & & & & 1915 \\
\hline MA & Worcester & 1900-1917 & & & & 1902 & & & & 1907 & 1904 \\
\hline MI & Adrian & $1906-1917$ & & & & & & & & 1911 & \\
\hline MI & Alpena & $1906-1917$ & & & & & & & & 1908 & \\
\hline MI & Ann Arbor & $1900-1917$ & & & & & & & & 1909 & \\
\hline MI & Battle Creek & $1900-1917$ & & & & & & & & 1909 & 1908 \\
\hline MI & Bay City & $1900-1917$ & & & & & & & & 1909 & 1907 \\
\hline MI & D etroit & $1900-1917$ & 1908 & & & & & 1906 & & 1905 & 1906 \\
\hline MI & Escanaba & $1900-1917$ & & & & & & & & 1909 & \\
\hline MI & Flint & $1900-1917$ & & & & & & & & 1910 & \\
\hline MI & G rand Rapids & $1900-1917$ & 1907 & & & & 1910 & 1905 & & 1905 & 1908 \\
\hline MI & Jackson & $1900-1917$ & & 1915 & & & & & & 1908 & 1916 \\
\hline MI & Kalamazoo & $1900-1917$ & 1914 & & 1909 & & & 1904 & & 1909 & 1912 \\
\hline
\end{tabular}


Appendix Table 1. Municipal-level Anti-TB Measures, 1900-1917 (continued)

\begin{tabular}{|c|c|c|c|c|c|c|c|c|c|c|c|}
\hline State & City & Years of available data & $\begin{array}{c}\text { First } \\
\text { sanatorium }\end{array}$ & $\begin{array}{l}\text { First TB } \\
\text { hospital }\end{array}$ & $\begin{array}{c}\text { First } \\
\text { open-air } \\
\text { camp }\end{array}$ & $\begin{array}{l}\text { Municipal } \\
\text { reporting } \\
\text { ordinance }\end{array}$ & $\begin{array}{c}\text { Municipal } \\
\text { disinfection } \\
\text { ordinance }\end{array}$ & $\begin{array}{l}\text { Municipal } \\
\text { spitting } \\
\text { ordinance }\end{array}$ & $\begin{array}{l}\text { Municipal } \\
\text { common } \\
\text { cup } \\
\text { ordinance }\end{array}$ & $\begin{array}{c}\text { Municipal } \\
\text { TB } \\
\text { association }\end{array}$ & $\begin{array}{c}\text { First } \\
\text { dispensary }\end{array}$ \\
\hline MI & Lansing & $1900-1917$ & 1913 & & & & & & & 1909 & 1914 \\
\hline MI & Manistee & 1906-1917 & 1915 & & & & & & & 1911 & \\
\hline MI & Marquette & 1900-1917 & 1911 & & & & & & & 1909 & 1917 \\
\hline MI & Muskegon & 1900-1917 & & 1915 & & & & & & 1908 & \\
\hline MI & Owosso & 1900-1909 & & & & & & & & 1908 & \\
\hline MI & Pontiac & 1900-1917 & & & & & & & & 1915 & \\
\hline MI & Port Huron & 1900-1917 & & & & & & & & 1915 & \\
\hline MI & Saginaw & 1900-1917 & & 1915 & & 1909 & 1909 & 1910 & & 1909 & 1909 \\
\hline MI & Sault Ste. Marie & 1900-1917 & & & & & & & & 1914 & \\
\hline MI & Traverse City & $1900-1917$ & & & & & & & & 1913 & \\
\hline $\mathrm{MN}$ & Duluth & $1900-1917$ & 1912 & 1915 & 1910 & 1905 & & 1905 & & 1908 & 1910 \\
\hline $\mathrm{MN}$ & Mankato & 1900-1917 & & & & & & & & 1908 & \\
\hline MN & Minneapolis & $1900-1917$ & & 1908 & 1908 & & & & & 1903 & \\
\hline $\mathrm{MN}$ & St. Paul & 1900-1917 & 1914 & & & 1904 & & & & 1908 & 1909 \\
\hline MN & Winona & 1900-1917 & & & & & & & & 1908 & \\
\hline MS & Jackson & $1915-1917$ & & & & & & & & 1916 & \\
\hline MO & Hannibal & 1911-1917 & & & & & & & & 1915 & \\
\hline MO & Jefferson City & 1911-1917 & & & & & & & & 1912 & \\
\hline MO & Kansas City & 1900-1917 & 1915 & & 1909 & 1908 & 1910 & 1906 & & 1907 & 1909 \\
\hline MO & St. Joseph & $1900-1917$ & & & & & & 1907 & & 1910 & 1911 \\
\hline MO & St. Louis & $1900-1917$ & & 1901 & 1913 & & & 1903 & & 1904 & \\
\hline MO & Springfield & 1911-1917 & & & & 1914 & 1914 & 1914 & 1914 & & \\
\hline MT & Billings & 1910-1917 & & & & & & & & 1911 & \\
\hline MT & Butte & 1910-1917 & & & & & & & & 1912 & 1916 \\
\hline $\mathrm{NE}$ & Lincoln & 1900-1917 & & & & & & 1905 & & & \\
\hline NE & Omaha & $1900-1917$ & & 1908 & & & & & & 1907 & 1912 \\
\hline $\mathrm{NH}$ & Concord & 1900-1917 & 1901 & & & & & & & 1908 & \\
\hline $\mathrm{NH}$ & Manchester & $1900-1917$ & & & & 1906 & & 1904 & & & 1916 \\
\hline NJ & Atlantic City & $1900-1917$ & & & & & & & & 1907 & \\
\hline $\mathrm{NJ}$ & Bayonne & 1900-1917 & & & & & & & & 1912 & 1912 \\
\hline NJ & Bloomfield & 1906-1917 & & & & & & & & 1913 & \\
\hline $\mathrm{NJ}$ & Bridgeton & $1900-1917$ & & & & & & & & 1906 & \\
\hline $\mathrm{NJ}$ & Camden & 1900-1917 & & & & & & & & 1908 & 1908 \\
\hline NJ & East Orange & 1906-1917 & & & & 1909 & 1909 & 1909 & & & \\
\hline $\mathrm{NJ}$ & Elizabeth & 1900-1917 & & & & 1913 & 1913 & & & 1906 & 1909 \\
\hline $\mathrm{NJ}$ & Garfield & $1910-1917$ & & & & & & & & 1913 & \\
\hline
\end{tabular}


Appendix Table 1. Municipal-level Anti-TB Measures, 1900-1917 (continued)

\begin{tabular}{|c|c|c|c|c|c|c|c|c|c|c|c|}
\hline State & City & Y ears of available data & $\begin{array}{c}\text { First } \\
\text { sanatorium }\end{array}$ & $\begin{array}{l}\text { First TB } \\
\text { hospital }\end{array}$ & $\begin{array}{l}\text { First } \\
\text { open-air } \\
\text { camp }\end{array}$ & $\begin{array}{l}\text { Municipal } \\
\text { reporting } \\
\text { ordinance }\end{array}$ & $\begin{array}{l}\text { Municipal } \\
\text { disinfection } \\
\text { ordinance }\end{array}$ & $\begin{array}{l}\text { Municipal } \\
\text { spitting } \\
\text { ordinance }\end{array}$ & $\begin{array}{l}\text { Municipal } \\
\text { common } \\
\text { cup } \\
\text { ordinance }\end{array}$ & $\begin{array}{l}\text { Municipal } \\
\text { TB } \\
\text { association }\end{array}$ & $\begin{array}{c}\text { First } \\
\text { dispensary }\end{array}$ \\
\hline NJ & Hackensack & $1906-1917$ & & & & & & & & 1911 & \\
\hline NJ & Hoboken & 1900-1917 & & & & & & & & 1913 & 1912 \\
\hline $\mathrm{NJ}$ & Jersey City & 1900-1917 & & & & & & & & 1909 & 1910 \\
\hline $\mathrm{NJ}$ & Kearny & 1906-1917 & & & & & & & & & 1914 \\
\hline $\mathrm{NJ}$ & Millville & 1900-1917 & & & & & & & & 1907 & \\
\hline $\mathrm{NJ}$ & Montclair & 1900-1917 & & & & & & & & 1907 & \\
\hline NJ & Morristown & 1900-1917 & & & & & & & & 1909 & 1909 \\
\hline NJ & Newark & 1900-1917 & 1908 & 1909 & 1909 & 1909 & 1909 & & & 1909 & 1908 \\
\hline $\mathrm{NJ}$ & Orange & 1900-1917 & & 1906 & 1909 & 1911 & 1908 & 1908 & & 1904 & 1904 \\
\hline $\mathrm{NJ}$ & Passaic & 1900-1917 & & & 1909 & 1910 & 1912 & 1904 & & 1913 & 1915 \\
\hline NJ & Paterson & 1900-1917 & & & 1910 & 1905 & 1911 & & & 1908 & 1909 \\
\hline $\mathrm{NJ}$ & Perth Amboy & 1900-1917 & & & & 1913 & & 1913 & 1913 & 1910 & 1917 \\
\hline NJ & Phillipsburg & $1900-1917$ & & & & & & & & 1910 & 1911 \\
\hline NJ & Plainfield & 1900-1917 & & & 1909 & & & & & & 1913 \\
\hline $\mathrm{NJ}$ & Trenton & 1900-1917 & & 1911 & & 1902 & 1902 & & & & 1912 \\
\hline $\mathrm{NJ}$ & Union & 1900-1917 & & 1912 & & & & & & & \\
\hline $\mathrm{NJ}$ & West Hoboken & 1907-1917 & & & & 1914 & 1914 & 1914 & & & \\
\hline NY & Albany & 1900-1917 & 1910 & & 1908 & & & 1908 & & 1908 & 1908 \\
\hline NY & Amsterdam & 1900-1917 & & & & & & & & 1910 & 1910 \\
\hline NY & Auburn & $1900-1917$ & 1912 & & & & & 1905 & & & \\
\hline NY & Batavia & 1906-1917 & & & & & & & & 1909 & \\
\hline NY & Binghamton & 1900-1917 & 1908 & & & & & 1907 & & 1907 & \\
\hline NY & Buffalo & 1900-1917 & 1914 & 1902 & 1908 & & & & 1910 & 1908 & 1907 \\
\hline NY & Cohoes & 1900-1917 & & & & & & & & 1909 & 1909 \\
\hline NY & Corning & 1900-1917 & & & 1915 & & & & & 1909 & 1912 \\
\hline NY & Cortland & 1900-1917 & & & & & & & & 1908 & \\
\hline NY & Dunkirk & 1900-1917 & & & & & & & & 1909 & 1910 \\
\hline NY & Elmira & 1900-1917 & 1909 & 1915 & & & & 1903 & & & 1914 \\
\hline NY & Geneva & 1900-1917 & & & & & & & & 1908 & \\
\hline NY & Glens Falls & 1900-1917 & & & & & & & & 1910 & 1911 \\
\hline NY & Gloversville & 1900-1917 & 1912 & & & & & & & 1911 & 1913 \\
\hline NY & Hornell & 1906-1917 & & & & & & & & 1909 & 1912 \\
\hline NY & Hudson & 1900-1917 & & & & & & & & 1909 & \\
\hline NY & Ithaca & 1900-1917 & 1912 & & & & & & & 1911 & 1911 \\
\hline NY & Jamestown & $1900-1917$ & & & & & & & & 1909 & 1910 \\
\hline NY & Johnstown & 1900-1917 & & & & & & & & 1910 & 1915 \\
\hline
\end{tabular}


Appendix Table 1. Municipal-level Anti-TB Measures, 1900-1917 (continued)

\begin{tabular}{|c|c|c|c|c|c|c|c|c|c|c|c|}
\hline State & City & Y ears of available data & $\begin{array}{c}\text { First } \\
\text { sanatorium }\end{array}$ & $\begin{array}{l}\text { First TB } \\
\text { hospital }\end{array}$ & $\begin{array}{l}\text { First } \\
\text { open-air } \\
\text { camp }\end{array}$ & $\begin{array}{l}\text { Municipal } \\
\text { reporting } \\
\text { ordinance }\end{array}$ & $\begin{array}{c}\text { Municipal } \\
\text { disinfection } \\
\text { ordinance }\end{array}$ & $\begin{array}{l}\text { Municipal } \\
\text { spitting } \\
\text { ordinance }\end{array}$ & $\begin{array}{l}\text { Municipal } \\
\text { common } \\
\text { cup } \\
\text { ordinance }\end{array}$ & $\begin{array}{c}\text { Municipal } \\
\text { TB } \\
\text { association }\end{array}$ & $\begin{array}{c}\text { First } \\
\text { dispensary }\end{array}$ \\
\hline $\mathrm{NY}$ & Kingston & $1900-1917$ & & 1909 & & & & & & 1909 & 1910 \\
\hline NY & Little Falls & 1906-1917 & & & & & & & & 1911 & 1912 \\
\hline NY & Lockport & $1900-1917$ & & & & & & & & 1910 & 1913 \\
\hline NY & Middletown & 1900-1917 & & & & & & & & 1909 & 1911 \\
\hline NY & Mount Vernon & $1900-1917$ & & & & 1914 & & 1907 & & & \\
\hline NY & New Y ork & $1900-1917$ & & & 1907 & & & & 1911 & 1902 & \\
\hline NY & Newburgh & 1900-1917 & 1910 & & 1914 & & & & & 1909 & 1912 \\
\hline NY & Niagara Falls & $1900-1917$ & & & & 1905 & 1905 & 1905 & & 1910 & 1910 \\
\hline NY & North Tonawanda & 1906-1917 & & & & & & & & 1912 & \\
\hline NY & Ogdensburg & $1900-1917$ & & & & & & & & 1910 & \\
\hline NY & Olean & $1900-1917$ & 1916 & & 1914 & & & & & 1909 & 1910 \\
\hline NY & Oswego & 1906-1917 & & & & & & & & 1909 & \\
\hline NY & Peekskill & $1900-1917$ & & & & & & & & & 1914 \\
\hline NY & Plattsburg & 1906-1917 & & & & & & & & 1910 & \\
\hline NY & Poughkeepsie & 1900-1917 & 1909 & & & & 1916 & 1907 & & 1909 & 1911 \\
\hline NY & Rochester & $1900-1917$ & 1910 & 1904 & 1908 & 1912 & & & 1912 & & \\
\hline NY & Rome & $1900-1917$ & & 1913 & & & & & & 1907 & 1908 \\
\hline NY & Saratoga Springs & $1900-1917$ & & & & & & & & 1910 & \\
\hline NY & Schenectady & $1900-1917$ & & 1908 & & 1908 & 1908 & 1906 & 1908 & 1908 & 1908 \\
\hline NY & Syracuse & $1900-1917$ & 1916 & 1909 & & & & 1908 & & 1909 & 1908 \\
\hline NY & Troy & $1900-1917$ & 1910 & & & & & 1904 & & 1908 & 1908 \\
\hline NY & Utica & $1900-1917$ & & & 1910 & & & & & 1907 & 1909 \\
\hline NY & Watertown & $1900-1917$ & & & & & & 1910 & & 1909 & 1910 \\
\hline NY & Watervliet & $1900-1917$ & & & & & & & & 1910 & 1910 \\
\hline NY & Yonkers & $1900-1917$ & & 1908 & & & & & & 1905 & 1906 \\
\hline NC & Durham & $1910-1917$ & & 1916 & & & & & & & \\
\hline $\mathrm{NC}$ & Raleigh & $1900-1917$ & & & & & & & & 1909 & \\
\hline $\mathrm{NC}$ & Wilmington & $1900-1917$ & 1914 & & & 1913 & 1913 & 1913 & 1914 & & \\
\hline NC & Winston-Salem & $1910-1917$ & 1917 & & & & & & & & \\
\hline $\mathrm{OH}$ & Akron & 1909-1917 & & & & & & & & 1917 & 1916 \\
\hline $\mathrm{OH}$ & Alliance & 1909-1917 & & & & & & & & 1914 & \\
\hline $\mathrm{OH}$ & Ashtabula & $1900-1917$ & & & & & & & & 1915 & \\
\hline $\mathrm{OH}$ & Bellaire & 1900-1917 & & & & & & & & 1912 & \\
\hline $\mathrm{OH}$ & Cambridge & $1909-1917$ & & & & & & & & 1914 & \\
\hline $\mathrm{OH}$ & Canton & $1900-1917$ & & & & 1907 & & 1902 & & 1910 & 1910 \\
\hline $\mathrm{OH}$ & Chillicothe & $1900-1917$ & & & & & & & & 1908 & 1911 \\
\hline
\end{tabular}


Appendix Table 1. Municipal-level Anti-TB Measures, 1900-1917 (continued)

\begin{tabular}{|c|c|c|c|c|c|c|c|c|c|c|c|}
\hline State & City & Y ears of available data & $\begin{array}{c}\text { First } \\
\text { sanatorium }\end{array}$ & $\begin{array}{l}\text { First TB } \\
\text { hospital }\end{array}$ & $\begin{array}{l}\text { First } \\
\text { open-air } \\
\text { camp }\end{array}$ & $\begin{array}{l}\text { Municipal } \\
\text { reporting } \\
\text { ordinance }\end{array}$ & $\begin{array}{l}\text { Municipal } \\
\text { disinfection } \\
\text { ordinance }\end{array}$ & $\begin{array}{l}\text { Municipal } \\
\text { spitting } \\
\text { ordinance }\end{array}$ & $\begin{array}{l}\text { Municipal } \\
\text { common } \\
\text { cup } \\
\text { ordinance }\end{array}$ & $\begin{array}{c}\text { Municipal } \\
\text { TB } \\
\text { association }\end{array}$ & $\begin{array}{c}\text { First } \\
\text { dispensary }\end{array}$ \\
\hline $\mathrm{OH}$ & Cincinnati & $1900-1917$ & & & 1910 & 1912 & 1912 & 1911 & 1912 & 1907 & 1907 \\
\hline $\mathrm{OH}$ & Cleveland & $1900-1917$ & 1905 & & 1908 & 1907 & 1901 & 1905 & 1909 & 1905 & 1904 \\
\hline $\mathrm{OH}$ & Columbus & $1900-1917$ & & & & 1906 & & 1906 & & 1906 & 1906 \\
\hline $\mathrm{OH}$ & Dayton & $1900-1917$ & & 1903 & & & & & & 1908 & 1914 \\
\hline $\mathrm{OH}$ & East Liverpool & $1909-1917$ & & & & & & & & 1914 & \\
\hline $\mathrm{OH}$ & Elyria & $1909-1917$ & & & & & & & & 1915 & \\
\hline $\mathrm{OH}$ & Hamilton & 1900-1917 & & 1913 & & 1913 & 1912 & 1910 & 1912 & 1912 & 1912 \\
\hline $\mathrm{OH}$ & Lancaster & 1909-1917 & & & & & & & & 1913 & \\
\hline $\mathrm{OH}$ & Lima & $1900-1917$ & & 1911 & & & & & & 1909 & \\
\hline $\mathrm{OH}$ & Mansfield & $1909-1917$ & & & & & & & & 1914 & \\
\hline $\mathrm{OH}$ & Marietta & $1900-1917$ & & & & & & & & 1914 & \\
\hline $\mathrm{OH}$ & Marion & $1909-1917$ & & & & & & & & 1912 & \\
\hline $\mathrm{OH}$ & Massillon & $1900-1917$ & & & & & & & & 1915 & \\
\hline $\mathrm{OH}$ & Newark & $1900-1917$ & & & & & & & & 1915 & \\
\hline $\mathrm{OH}$ & Piqua & $1909-1917$ & & & & & & & & 1915 & \\
\hline $\mathrm{OH}$ & Portsmouth & $1900-1917$ & & & & & & & & 1911 & 1914 \\
\hline $\mathrm{OH}$ & Sandusky & $1909-1917$ & & & & & & & & 1913 & \\
\hline $\mathrm{OH}$ & Springfield & $1909-1917$ & & 1910 & & & & & & & 1915 \\
\hline $\mathrm{OH}$ & Steubenville & $1909-1917$ & & & & & & & & 1910 & 1917 \\
\hline $\mathrm{OH}$ & Tiffin & $1900-1917$ & & & & & & & & 1915 & \\
\hline $\mathrm{OH}$ & Toledo & 1900-1917 & & 1909 & 1910 & & & & & 1909 & 1905 \\
\hline $\mathrm{OH}$ & Warren & $1900,1909-1917$ & & & & & & & & 1913 & 1914 \\
\hline $\mathrm{OH}$ & Youngstown & 1900-1917 & & 1908 & & 1905 & & 1902 & & 1905 & 1914 \\
\hline $\mathrm{OH}$ & Zanesville & 1909-1917 & & & & & & & & 1914 & \\
\hline OR & Portland & $1900-1917$ & & & 1905 & 1909 & 1909 & 1904 & 1914 & 1909 & 1910 \\
\hline PA & Allentown & $1900-1917$ & & & & & 1902 & 1910 & & 1908 & 1908 \\
\hline $\mathrm{PA}$ & Altoona & $1900-1917$ & & & & 1902 & & 1904 & & 1913 & 1907 \\
\hline PA & Beaver Falls & $1906-1917$ & & & & & & & & 1915 & 1908 \\
\hline PA & Braddock & 1906-1917 & & & & & & & & & 1909 \\
\hline PA & Bradford & 1906-1917 & 1908 & & & & & & & 1909 & 1908 \\
\hline PA & Butler & $1906-1917$ & & & & & & & & 1916 & 1907 \\
\hline PA & Carbondale & $1900-1917$ & & & & & & & & 1915 & 1908 \\
\hline PA & Carlisle & $1900-1917$ & & & & & & & & 1915 & 1907 \\
\hline PA & Chambersburg & 1906-1917 & & & & & & & & & 1907 \\
\hline PA & Chester & 1906-1917 & & & & & & & & 1916 & 1907 \\
\hline PA & Coatesville & 1910-1917 & & & & & & & & 1916 & \\
\hline
\end{tabular}


Appendix Table 1. Municipal-level Anti-TB Measures, 1900-1917 (continued)

\begin{tabular}{|c|c|c|c|c|c|c|c|c|c|c|c|}
\hline State & City & Years of available data & $\begin{array}{c}\text { First } \\
\text { sanatorium }\end{array}$ & $\begin{array}{l}\text { First TB } \\
\text { hospital }\end{array}$ & $\begin{array}{l}\text { First } \\
\text { open-air } \\
\text { camp }\end{array}$ & $\begin{array}{l}\text { Municipal } \\
\text { reporting } \\
\text { ordinance }\end{array}$ & $\begin{array}{l}\text { Municipal } \\
\text { disinfection } \\
\text { ordinance }\end{array}$ & $\begin{array}{c}\text { Municipal } \\
\text { spitting } \\
\text { ordinance }\end{array}$ & $\begin{array}{l}\text { Municipal } \\
\text { common } \\
\text { cup } \\
\text { ordinance }\end{array}$ & $\begin{array}{c}\text { Municipal } \\
\text { TB } \\
\text { association }\end{array}$ & $\begin{array}{c}\text { First } \\
\text { dispensary } \\
\end{array}$ \\
\hline $\mathrm{PA}$ & Columbia & $1900-1917$ & & & & & & & & 1915 & 1908 \\
\hline PA & D anville & 1906-1909 & & & & & & & & & 1907 \\
\hline $\mathrm{PA}$ & Dubois & 1900-1917 & & & & & & & & 1915 & 1908 \\
\hline PA & Easton & $1900,1906-1917$ & & & & & & & & 1908 & 1908 \\
\hline PA & Erie & $1900-1917$ & & & & & & & & 1910 & 1907 \\
\hline PA & Harrisburg & $1900-1917$ & & & & & & & 1915 & 1905 & 1908 \\
\hline PA & Hazleton & 1900-1917 & & & & & & & & 1908 & 1908 \\
\hline PA & Homestead & 1906-1917 & & & & & & & & & 1908 \\
\hline $\mathrm{PA}$ & Johnstown & $1900-1917$ & & & & 1907 & & 1903 & & 1914 & 1907 \\
\hline PA & Lancaster & 1900-1917 & & & & & & & & 1908 & 1908 \\
\hline PA & Lebanon & $1900,1906-1917$ & & & & & & & & & 1907 \\
\hline PA & McKeesport & 1900-1917 & & & & & & 1907 & & & 1908 \\
\hline PA & Meadville & $1900-1917$ & & & & & & & & 1915 & 1908 \\
\hline PA & Mount Carmel & $1900-1917$ & & & & & & & & & 1908 \\
\hline PA & Nanticoke & 1906-1917 & & & & & & & & 1915 & 1910 \\
\hline PA & New Castle & 1900-1917 & & & & 1907 & 1907 & 1907 & & & 1908 \\
\hline $\mathrm{PA}$ & Norristown & 1900-1917 & & & & & & & & 1916 & 1908 \\
\hline PA & Oil City & $1900,1906-1917$ & 1904 & & & & & & & & 1907 \\
\hline PA & Philadelphia & $1900-1917$ & & & & & & 1903 & & 1903 & 1903 \\
\hline PA & Phoenixville & $1900,1906-1917$ & & & & & & & & & 1908 \\
\hline PA & Pittsburgh & $1900-1917$ & & 1906 & & 1907 & & 1906 & & 1908 & 1907 \\
\hline PA & Pittston & 1906-1917 & & & & & & & & & 1908 \\
\hline PA & Plymouth & 1900-1917 & & & & & & & & 1915 & \\
\hline PA & Pottstown & 1900-1917 & & & & & & & & 1916 & 1908 \\
\hline $\mathrm{PA}$ & Pottsville & $1900-1917$ & & & & & & & & 1908 & 1908 \\
\hline PA & Reading & $1900-1917$ & 1910 & & & & & & & 1909 & 1908 \\
\hline PA & Scranton & $1900-1917$ & 1903 & & & 1908 & & 1907 & & 1903 & 1908 \\
\hline PA & Shamokin & 1906-1917 & & & & & & & & & 1908 \\
\hline PA & Sharon & 1906-1917 & & & & & & & & 1915 & 1908 \\
\hline $\mathrm{PA}$ & Shenandoah & $1906-1917$ & & & & & & & & & 1908 \\
\hline PA & South Bethlehem & $1900-1917$ & & & & & & & & & 1908 \\
\hline PA & Sunbury & $1906-1917$ & & & & & & & & 1916 & 1909 \\
\hline $\mathrm{PA}$ & Titusville & 1906-1909 & & & & & & & & & 1908 \\
\hline PA & Warren & 1906-1917 & 1910 & & & & & & & & 1908 \\
\hline PA & Washington & $1910-1917$ & & & & & & & & 1915 & \\
\hline $\mathrm{PA}$ & West Chester & $1906-1917$ & & & & & & & & & 1907 \\
\hline
\end{tabular}


Appendix Table 1. Municipal-level Anti-TB Measures, 1900-1917 (continued)

\begin{tabular}{|c|c|c|c|c|c|c|c|c|c|c|c|}
\hline State & City & Y ears of available data & $\begin{array}{c}\text { First } \\
\text { sanatorium }\end{array}$ & $\begin{array}{l}\text { First TB } \\
\text { hospital }\end{array}$ & $\begin{array}{l}\text { First } \\
\text { open-air } \\
\text { camp }\end{array}$ & $\begin{array}{l}\text { Municipal } \\
\text { reporting } \\
\text { ordinance }\end{array}$ & $\begin{array}{l}\text { Municipal } \\
\text { disinfection } \\
\text { ordinance }\end{array}$ & $\begin{array}{l}\text { Municipal } \\
\text { spitting } \\
\text { ordinance }\end{array}$ & $\begin{array}{l}\text { Municipal } \\
\text { common } \\
\text { cup } \\
\text { ordinance }\end{array}$ & $\begin{array}{l}\text { Municipal } \\
\text { TB } \\
\text { association }\end{array}$ & $\begin{array}{c}\text { First } \\
\text { dispensary }\end{array}$ \\
\hline $\mathrm{PA}$ & Wilkes-Barre & $1906-1917$ & & & & & & & & & 1907 \\
\hline PA & Wilkinsburg & 1906-1917 & & & & & & & & 1908 & 1909 \\
\hline PA & Williamsport & $1900-1917$ & & & & 1905 & 1905 & 1905 & & 1910 & 1908 \\
\hline PA & York & 1906-1917 & & & & & & & & 1914 & 1907 \\
\hline RI & Cranston & 1906-1917 & & & & & & & & 1910 & \\
\hline $\mathrm{RI}$ & East Providence & $1906-1917$ & & & & & & & & 1910 & \\
\hline $\mathrm{RI}$ & Newport & 1900-1917 & & & & 1903 & 1903 & 1902 & & 1904 & 1904 \\
\hline $\mathrm{RI}$ & Pawtucket & $1900-1917$ & & & & & & 1906 & & 1908 & 1908 \\
\hline $\mathrm{RI}$ & Providence & $1900-1917$ & & 1905 & 1908 & & & & & 1905 & \\
\hline $\mathrm{RI}$ & Warwick & $1906-1917$ & & & & & & & & 1914 & \\
\hline $\mathrm{RI}$ & Woonsocket & $1900-1917$ & & & & & & 1909 & & 1908 & 1915 \\
\hline $\mathrm{SC}$ & Charleston & 1900-1917 & & & & & & & & 1909 & 1909 \\
\hline $\mathrm{TN}$ & Memphis & 1900-1915, 1917 & & 1908 & & 1908 & & 1905 & & 1917 & 1912 \\
\hline $\mathrm{TN}$ & Nashville & 1900-1915, 1917 & & 1912 & & 1907 & & & & 1906 & 1911 \\
\hline TX & Dallas & 1916-1917 & & & 1917 & & & & & & \\
\hline $\mathrm{TX}$ & El Paso & 1911-1917 & & & & & & & & 1916 & \\
\hline TX & Galveston & $1906-1917$ & & 1913 & & 1907 & & & & 1911 & \\
\hline $\mathrm{TX}$ & San Antonio & $1900-1917$ & 1912 & & 1907 & 1908 & & & 1915 & 1915 & \\
\hline UT & Ogden & $1908-1917$ & & & & & 1911 & 1913 & 1911 & & \\
\hline UT & Salt Lake City & $1900-1917$ & & & & 1913 & 1913 & 1903 & 1913 & 1916 & \\
\hline VA & Alexandria & $1900-1917$ & & & & & & & & 1910 & \\
\hline VA & D anville & $1908-1917$ & 1915 & & & & & & & & \\
\hline VA & Lynchburg & $1900-1917$ & & 1912 & & 1910 & 1910 & 1910 & & 1908 & \\
\hline VA & Norfolk & $1900-1917$ & & & 1909 & 1906 & & & & 1906 & 1906 \\
\hline VA & Petersburg & $1900-1917$ & 1911 & & & & & & & 1908 & \\
\hline VA & Richmond & 1900-1917 & & & 1910 & 1907 & & & & 1909 & 1907 \\
\hline WA & Everett & $1910-1917$ & & & & 1914 & 1914 & & & & \\
\hline WA & Seattle & $1900-1917$ & 1911 & 1903 & & 1907 & 1907 & 1907 & 1911 & 1909 & 1910 \\
\hline WA & Spokane & $1901-1917$ & 1915 & & & 1915 & & & & 1911 & \\
\hline WA & Tacoma & $1900-1917$ & & & & 1909 & 1909 & & & 1910 & 1915 \\
\hline WA & Walla Walla & $1908-1917$ & & & & & & & & 1916 & \\
\hline WV & Wheeling & $1900-1917$ & & & & 1908 & & 1902 & & 1909 & 1910 \\
\hline WI & Appleton & 1900-1906, 1908-1917 & & & & & & & & 1911 & \\
\hline WI & Ashland & 1908-1917 & & & & & & & & 1911 & \\
\hline WI & Eau Claire & $1900-1917$ & 1913 & & & & & & & 1909 & \\
\hline WI & Fond du Lac & 1908-1917 & & & & & & & & 1911 & \\
\hline
\end{tabular}


Appendix Table 1. Municipal-level Anti-TB Measures, 1900-1917 (continued)

\begin{tabular}{|c|c|c|c|c|c|c|c|c|c|c|c|}
\hline State & City & Y ears of available data & $\begin{array}{c}\text { First } \\
\text { sanatorium }\end{array}$ & $\begin{array}{l}\text { First TB } \\
\text { hospital }\end{array}$ & $\begin{array}{l}\text { First } \\
\text { open-air } \\
\text { camp }\end{array}$ & $\begin{array}{l}\text { Municipal } \\
\text { reporting } \\
\text { ordinance }\end{array}$ & $\begin{array}{l}\text { Municipal } \\
\text { disinfection } \\
\text { ordinance }\end{array}$ & $\begin{array}{l}\text { Municipal } \\
\text { spitting } \\
\text { ordinance }\end{array}$ & $\begin{array}{l}\text { Municipal } \\
\text { common } \\
\text { cup } \\
\text { ordinance }\end{array}$ & $\begin{array}{l}\text { Municipal } \\
\text { TB } \\
\text { association }\end{array}$ & $\begin{array}{c}\text { First } \\
\text { dispensary }\end{array}$ \\
\hline$\overline{\mathrm{WI}}$ & Green Bay & $1900-1917$ & & & & & & & & 1911 & \\
\hline WI & Janesville & 1908-1917 & & & & & & & & 1912 & \\
\hline WI & Kenosha & 1900-1917 & 1916 & & & & & & & & \\
\hline WI & La Crosse & 1908-1917 & & & & & & & & 1910 & \\
\hline WI & Madison & 1900-1917 & 1917 & & & & & & & 1909 & 1910 \\
\hline WI & Manitowoc & 1900-1905, 1908-1917 & 1912 & & & & & & & 1911 & \\
\hline WI & Marinette & 1900-1917 & & & & & & & & 1912 & \\
\hline WI & Milwaukee & 1900-1917 & 1907 & 1907 & & & & 1905 & & 1904 & 1908 \\
\hline WI & Racine & 1908-1917 & 1913 & & & & & & & 1909 & \\
\hline WI & Sheboygan & $1908-1917$ & & & & & & & & 1910 & \\
\hline WI & Supenior & 1900-1917 & & & & 1910 & & & & 1908 & \\
\hline WI & Wausau & 1908-1917 & 1917 & & & & & & & 1910 & 1911 \\
\hline
\end{tabular}

Notes: D ata on municipal-level anti-TB interventions come from A TubecalosisDiretory, published in 1911, 1916, and 1919 by the National Association for the Study and Prevention of Tuberculosis. D ates are listed only for cities with mortality data available before and after the specific anti-TB measure was implemented. 


\section{Appendix Table 2. State-level Anti-TB Measures, 1900-1917}

\begin{tabular}{|c|c|c|c|c|c|c|}
\hline State & & State reporting law & $\begin{array}{l}\text { State disinfection } \\
\text { ordinance }\end{array}$ & State common cup law & State TB association & $\begin{array}{l}\text { First state-run } \\
\text { sanatorium }\end{array}$ \\
\hline \multirow[t]{3}{*}{$\mathrm{AL}$} & & & & & 1914 & \\
\hline & Cities with mortality data pre- & & & & Birmingham, Mobile, & \\
\hline & and post-state policy change & & & & Montgomery & \\
\hline \multirow[t]{6}{*}{$\mathrm{CA}$} & & & & & $1907^{-1}$ & \\
\hline & Cities with mortality data pre- & & & & Alameda, Berkeley, & \\
\hline & and post-state policy change & & & & Fresno, Los Angeles, & \\
\hline & & & & & Sacramento, San Diego, & \\
\hline & & & & & San Francisco, San Jose, & \\
\hline & & "1911 & 1913 & 19̄în........... & Stockton & \\
\hline \multirow{2}{*}{$\overline{C O}$} & Cities with mortality data pre- & Colorado Springs, & Colorado Springs, & Colorado Springs, & Colorado Springs, & \\
\hline & and post-state policy change & Denver, Pueblo & D enver, Pueblo & D enver, Pueblo & Denver, Pueblo & \\
\hline \multirow[t]{8}{*}{$\mathrm{CT}^{-}$} & & $1 \overline{9} 0 \overline{9}$ & & & $190 \overline{9}^{-\cdots}$ & $\overline{1} \overline{0} \overline{9}$ \\
\hline & Cities with mortality data pre- & Bridgeport, Bristol, & & & Bridgeport, Bristol, & Bridgeport, Bristol, \\
\hline & and post-state policy change & Greenwich, Hartford, & & & G reenwich, Hartford, & Greenwich, Hartford, \\
\hline & & Meriden, Middletown, & & & Meriden, Middletown, & Meriden, Middletown, \\
\hline & & New Britain, New Haven, & & & New Britain, New & New Britain, New \\
\hline & & New London, Norwalk, & & & Haven, New London, & Haven, New London, \\
\hline & & Stamford, Wallingford, & & & Norwalk, Stamford, & Norwalk, Stamford, \\
\hline & 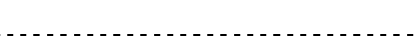 & Waterbury & $=1014$ & & Wallingford, Waterbury & Wallingford, Waterbury \\
\hline \multirow{2}{*}{$\overline{\mathrm{DE}}$} & Cities with mortality data pre- & & Wilmington & & $\begin{array}{c}1906 \\
\text { Wilmington }\end{array}$ & \\
\hline & and post-state policy change & & & & & \\
\hline \multirow[t]{2}{*}{$\mathrm{FL}^{-}$} & 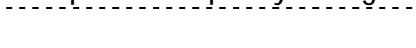 & & & & $191 \overline{6}^{-\cdots}$ & \\
\hline & Cities with mortality data pre- & & & & Jacksonville, Tampa & \\
\hline \multirow{3}{*}{$\mathrm{GA}$} & 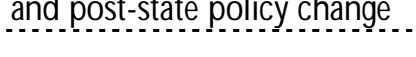 & & & & $190 \bar{g}^{--}$ & jōi \\
\hline & Cities with mortality data pre- & & & & Atlanta, Savannah & Atlanta. Savannah \\
\hline & and post-state policy change & & & & & \\
\hline \multirow[t]{4}{*}{$\mathrm{II}^{--}$} & & & 1914 & & 1905 & \\
\hline & Cities with mortality data pre- & & Aurora, Chicago, & & Aurora, Chicago, & \\
\hline & and post-state policy change & & D ecatur, Evanston, & & D ecatur, Jacksonville, & \\
\hline & & & $\begin{array}{l}\text { Jacksonville, Q uuncy, } \\
\text { Springfield }\end{array}$ & & $\begin{array}{l}\text { Uttawa, Quincy, } \\
\text { Springfield }\end{array}$ & \\
\hline
\end{tabular}




\section{Appendix Table 2. State-level Anti-TB Measures, 1900-1917 (continued)}

\begin{tabular}{|c|c|c|c|c|c|c|}
\hline State & & State reporting law & $\begin{array}{l}\text { State disinfection } \\
\text { ordinance }\end{array}$ & State common cup law & State TB association & $\begin{array}{l}\text { First state-run } \\
\text { sanatorium }\end{array}$ \\
\hline \multirow{8}{*}{ IN } & & 1907 & 1913 & & 1907 & 1911 \\
\hline & Cities with mortality data pre- & Anderson, Elkhart, & Anderson, Elkhart, & & Anderson, Elkhart, & Anderson, Elkhart, \\
\hline & and post-state policy change & Evansville, Fort Wayne, & Evansville, Fort Wayne, & & Evansville, Fort Wayne, & Evansville, Fort Wayne, \\
\hline & & $\begin{array}{l}\text { Huntington, Indianapolis, } \\
\text { Kokomo, Lafayette, }\end{array}$ & $\begin{array}{l}\text { Gary, Huntington, } \\
\text { Indianapolis, Kokomo, }\end{array}$ & & $\begin{array}{l}\text { Huntington, Indianapolis, } \\
\text { Kokomo, Lafayette, }\end{array}$ & $\begin{array}{l}\text { Gary, Huntington, } \\
\text { Indianapolis, Kokomo, }\end{array}$ \\
\hline & & Logansport, Muncie, & Lafayette, Logansport, & & Logansport, Muncie, & Lafayette, Logansport, \\
\hline & & New Albany, Peru, & Muncie, New Albany, & & New Albany, Peru, & Muncie, New Albany, \\
\hline & & Richmond, South Bend, & Peru, Richmond, South & & Richmond, South Bend, & Peru, Richmond, South \\
\hline & & Terre Haute & Bend, Terre Haute & & Terre Haute & Bend, Terre Haute \\
\hline \multirow{2}{*}{$\overline{\mathrm{KS}}{ }^{-}$} & & 1909 & & & 1908 & 1914 \\
\hline & $\begin{array}{l}\text { Cities with mortality data pre- } \\
\text { and post-state policy change }\end{array}$ & Kansas City, Wichita & & & Kansas City, Wichita & $\begin{array}{c}\text { Kansas City, Topeka, } \\
\text { Wichita }\end{array}$ \\
\hline \multirow[t]{2}{*}{$\overline{\mathrm{K}} \bar{Y}^{-}$} & & & & & $190 \overline{9}^{-}$ & \\
\hline & $\begin{array}{l}\text { Cities with mortality data pre- } \\
\text { and post-state policy chance }\end{array}$ & & & & $\begin{array}{l}\text { Covington, Louisville, } \\
\text { Newport, Paducah }\end{array}$ & \\
\hline \multirow[t]{2}{*}{$\overline{\mathrm{LA}}$} & & 1909 & & & 1906 & \\
\hline & $\begin{array}{l}\text { Cities with mortality data pre- } \\
\text { and post-state policy change }\end{array}$ & New Orleans & & & New Orleans & \\
\hline \multirow[t]{3}{*}{$\mathrm{ME}^{--}$} & & 1895 & 1913 & & 1901 & 1915 \\
\hline & Cities with mortality data pre- & & Auburn, Augusta, Bangor, & & Augusta, Bangor, & Auburn, Augusta, \\
\hline & and post-state policy change & & $\begin{array}{l}\text { Lewiston, Portland, } \\
\text { Waterville }\end{array}$ & & Portland & $\begin{array}{l}\text { Bangor, Lewiston, } \\
\text { Portland, Waterville }\end{array}$ \\
\hline \multirow[t]{2}{*}{$\mathrm{MD}^{--}$} & & $1904^{-1}$ & & 1912 & $1904^{-\cdots}$ & 1908 \\
\hline & $\begin{array}{l}\text { Cities with mortality data pre- } \\
\text { and post-state policy change }\end{array}$ & $\begin{array}{c}\text { Annapolis, Baltimore, } \\
\text { Frederick }\end{array}$ & & $\begin{array}{l}\text { Baltimore, Cumberland, } \\
\text { Frederick, Hagerstown }\end{array}$ & $\begin{array}{c}\text { Annapolis, Baltimore, } \\
\text { Frederick }\end{array}$ & $\begin{array}{c}\text { Annapolis, Baltimore, } \\
\text { Cumberland, Frederick, } \\
\text { Hagerstown }\end{array}$ \\
\hline
\end{tabular}




\section{Appendix Table 2. State-level Anti-TB Measures, 1900-1917 (continued)}

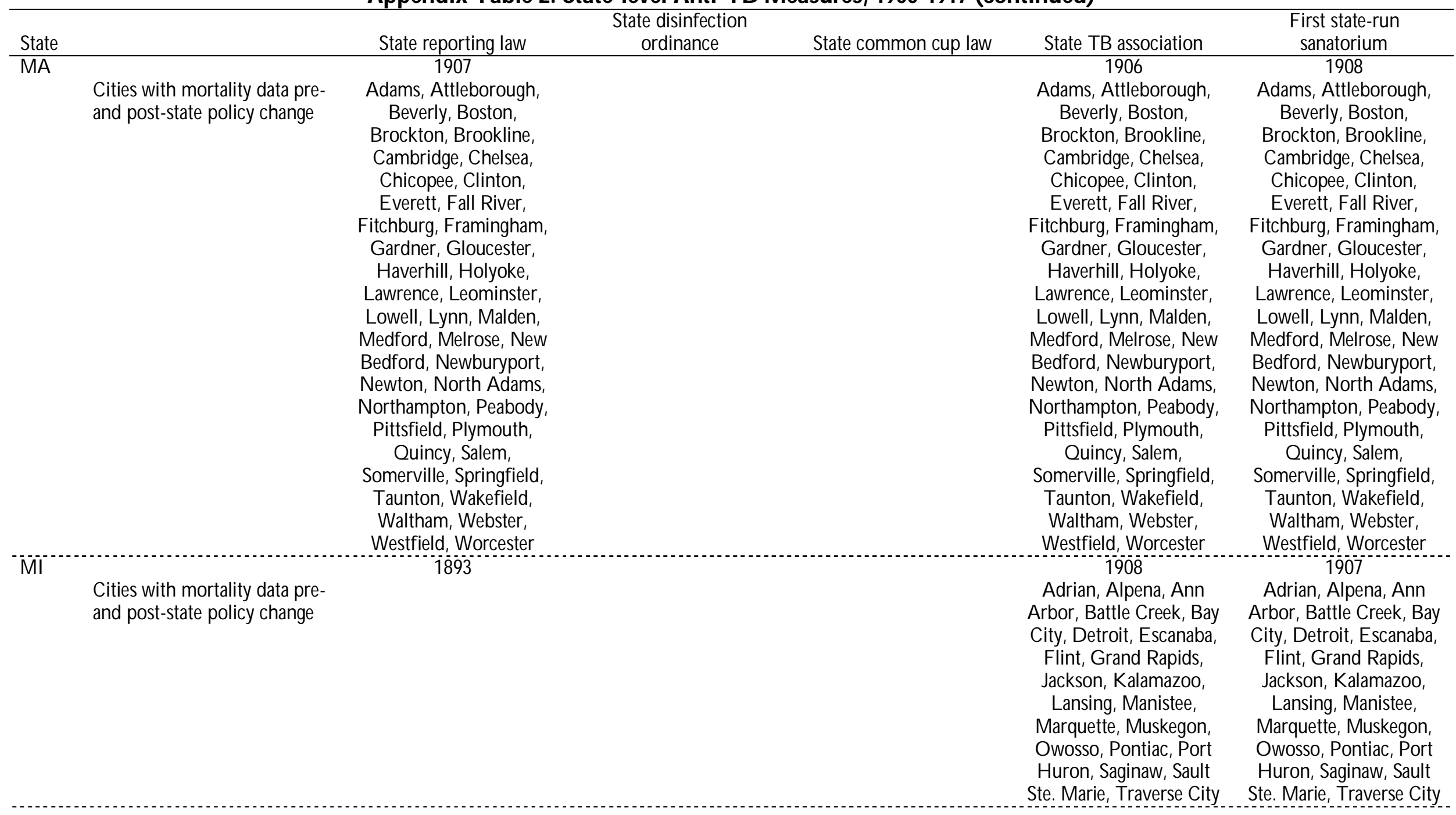




\section{Appendix Table 2. State-level Anti-TB Measures, 1900-1917 (continued)}

\begin{tabular}{|c|c|c|c|c|c|c|}
\hline State & & State reporting law & $\begin{array}{l}\text { State disinfection } \\
\text { ordinance }\end{array}$ & State common cup law & State TB association & $\begin{array}{l}\text { First state-run } \\
\text { sanatorium }\end{array}$ \\
\hline \multirow{4}{*}{$\mathrm{MN}$} & & & 1913 & 1913 & 1908 & 1908 \\
\hline & Cities with mortality data pre- & & Duluth, Mankato, & Duluth, Mankato, & Duluth, Mankato, & Duluth, Mankato, \\
\hline & and post-state policy change & & Minneapolis, St. Paul, & Minneapolis, St. Paul, & Minneapolis, St. Paul, & Minneapolis, St. Paul, \\
\hline & & & Winona & Winona & Winona & Winona \\
\hline \multirow{2}{*}{$\mathrm{MO}^{--}$} & & & & & $1907^{-\cdots}$ & 1907 \\
\hline & Cities with mortality data pre- & & & & Kansas City, St. Joseph, & Kansas City, St. Joseph, \\
\hline \multirow[t]{3}{*}{$\mathrm{MT}^{-}$} & & $19 \overline{1}$ & 1913 & $\overline{19} \overline{1} \overline{3}-$ & 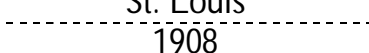 & . \\
\hline & Cities with mortality data pre- & Billings, Butte & Billings, Butte & Billings, Butte & & Billings, Butte \\
\hline & and post-state policy change & & & & & \\
\hline \multirow[t]{2}{*}{$\overline{\mathrm{N}} \mathrm{E}^{-}$} & & 1909 & & 1913 & $1907^{-\cdots}$ & $19 \overline{1} 12$ \\
\hline & Cities with mortality data pre- & Lincoln, O maha & & Lincoln, Omaha & Lincoln, O maha & Lincoln, O maha \\
\hline \multirow{3}{*}{$\mathrm{N}_{\mathrm{H}}^{--}$} & & & & & $190 \overline{6}$ & $-\overline{1} \overline{0} \overline{9}$ \\
\hline & Cities with mortality data pre- & & & & Concord, Manchester & Concord, Manchester \\
\hline & and post-state policy change & & & & & \\
\hline \multirow[t]{12}{*}{$\overline{\mathrm{N}} \overline{\mathrm{J}}$} & & 1909 & & 1911 & 1906 & 1907 \\
\hline & Cities with mortality data pre- & Atlantic City, Bayonne, & & Atlantic City, Bayonne, & Atlantic City, Bayonne, & Atlantic City, Bayonne, \\
\hline & and post-state policy change & Bloomfield, Bridgeton, & & Bloomfield, Bridgeton, & Bloomfield, Bridgeton, & Bloomfield, Bridgeton, \\
\hline & & Camden, East O range, & & Camden, E ast O range, & Camden, East O range, & Camden, E ast O range, \\
\hline & & Elizabeth, Hackensack, & & Elizabeth, Garfield, & Elizabeth, Hackensack, & Elizabeth, Hackensack, \\
\hline & & $\begin{array}{l}\text { Hoboken, Jersey City, } \\
\text { Kearny, Millville, }\end{array}$ & & $\begin{array}{l}\text { Hackensack, Hoboken, } \\
\text { Jersey City, Kearny, }\end{array}$ & $\begin{array}{l}\text { Hoboken, Jersey City, } \\
\text { Kearny, Millville, }\end{array}$ & $\begin{array}{l}\text { Hoboken, Jersey City, } \\
\text { Kearny, Millville, }\end{array}$ \\
\hline & & Montclair, Morristown, & & Millville, Montclair, & Montclair, Morristown, & Montclair, Morristown, \\
\hline & & Newark, O range, Passaic, & & Morristown, Newark, & Newark, O range, Passaic, & Newark, O range, \\
\hline & & Paterson, Perth Amboy, & & Orange, Passaic, & Paterson, Perth Amboy, & Passaic, Paterson, Perth \\
\hline & & Phillipsburg, Plainfield, & & Paterson, Perth Amboy, & Phillipsburg, Plainfield, & Amboy, Phillipsburg, \\
\hline & & Trenton, Union, West & & Phillipsburg, Plainfield, & Trenton, Union & Plainfield, Trenton, \\
\hline & & & & $\begin{array}{l}\text { Trenton, Union, West } \\
\text { Hoboken }\end{array}$ & & \\
\hline
\end{tabular}




\section{Appendix Table 2. State-level Anti-TB Measures, 1900-1917 (continued)}

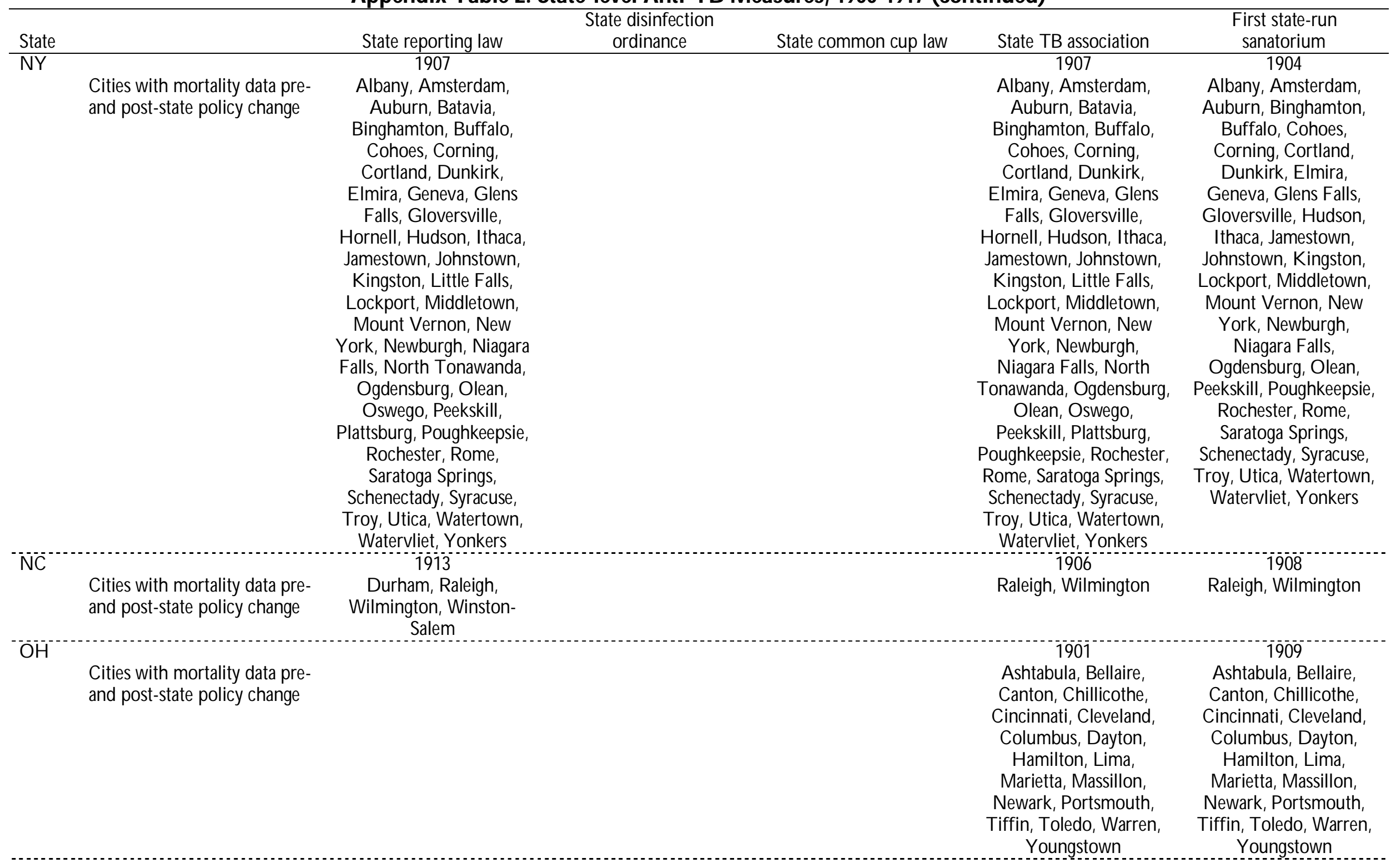




\section{Appendix Table 2. State-level Anti-TB Measures, 1900-1917 (continued)}

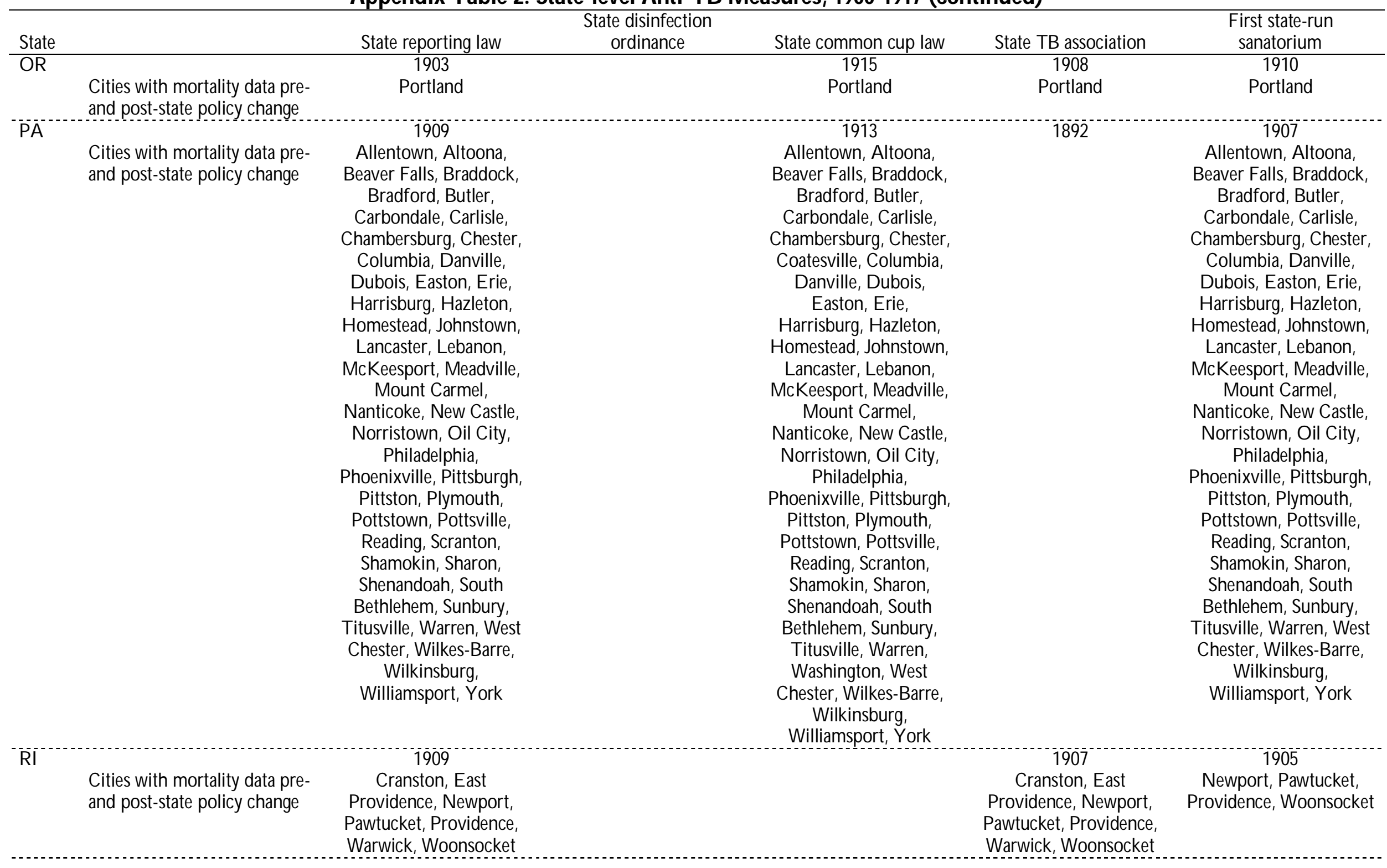




\section{Appendix Table 2. State-level Anti-TB Measures, 1900-1917 (continued)}

\begin{tabular}{|c|c|c|c|c|c|c|}
\hline State & & State reporting law & $\begin{array}{l}\text { State disinfection } \\
\text { ordinance }\end{array}$ & State common cup law & State TB association & $\begin{array}{l}\text { First state-run } \\
\text { sanatorium }\end{array}$ \\
\hline \multirow[t]{2}{*}{$\mathrm{SC}$} & & & & & 1913 & 1915 \\
\hline & $\begin{array}{l}\text { Cities with mortality data pre- } \\
\text { and post-state policy change }\end{array}$ & & & & Charleston & Charleston \\
\hline \multirow[t]{2}{*}{$\mathrm{TN}$} & & 1905 & & & 1912 & \\
\hline & $\begin{array}{l}\text { Cities with mortality data pre- } \\
\text { and post-state policy change }\end{array}$ & Memphis, Nashville & & & Memphis, Nashville & \\
\hline \multirow[t]{2}{*}{$\overline{\mathrm{T}} \overline{\mathrm{X}}^{-}$} & & 1911 & & & $1908^{-\cdots}$ & $19 \overline{1} 2^{-\cdots}$ \\
\hline & $\begin{array}{l}\text { Cities with mortality data pre- } \\
\text { and post-state policy change }\end{array}$ & Galveston, San Antonio & & & Galveston, San Antonio & $\begin{array}{l}\text { El Paso, Galveston, San } \\
\text { Antonio }\end{array}$ \\
\hline \multirow[t]{2}{*}{$\overline{\mathrm{UT}}$} & & 1913 & 1913 & & $191 \overline{6}^{-1}$ & \\
\hline & $\begin{array}{l}\text { Cities with mortality data pre- } \\
\text { and post-state policy change }\end{array}$ & O gden, Salt Lake City & O gden, Salt Lake City & & O gden, Salt Lake City & \\
\hline \multirow{4}{*}{$\overline{\mathrm{V}} \bar{A}^{-\cdot-}$} & & 1910 & 1908 & & $1909^{-\cdots}$ & $1900 \bar{g}^{-\cdots}$ \\
\hline & Cities with mortality data pre- & Alexandria, D anville, & Alexandria, Lynchburg, & & Alexandria, D anville, & Alexandria, Danville, \\
\hline & and post-state policy change & Lynchburg, Norfolk, & Norfolk, Petersburg, & & Lynchburg, Norfolk, & Lynchburg, Norfolk, \\
\hline & & Petersburg, Richmond & Richmond & & Petersburg, Richmond & Petersburg, Richmond \\
\hline \multirow{2}{*}{ WA } & Cities with mortality data pre- & $\begin{array}{c}1903 \\
\text { Seattle, Spokane, Tacoma }\end{array}$ & & $\begin{array}{c}1912 \\
\text { Everett Seattle }\end{array}$ & $\begin{array}{c}1906 \\
\text { Seattle Spokane Tacoma }\end{array}$ & \\
\hline & and post-state policy change & 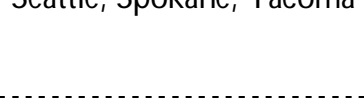 & & $\begin{array}{c}\text { Spokane, Tacoma, Walla } \\
\text { Walla }\end{array}$ & 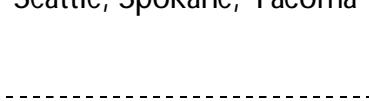 & \\
\hline \multirow[t]{2}{*}{$\overline{\mathrm{W}} \overline{\mathrm{V}} \overline{\mathrm{N}}^{--}$} & & & & $19 \overline{1} \overline{3}$ & $190 \overline{8}$ & $19 \overline{13}$ \\
\hline & $\begin{array}{l}\text { Cities with mortality data pre- } \\
\text { and post-state policy change }\end{array}$ & & & Wheeling & Wheeling & Wheeling \\
\hline \multirow[t]{2}{*}{$\overline{\mathrm{W}} \overline{\mathrm{I}}^{--}$} & & 1907 & $1907^{-1}$ & $19 \overline{1} 3^{-\cdots}$ & $1908^{-12}$ & 1907 \\
\hline & $\begin{array}{l}\text { Cities with mortality data pre- } \\
\text { and post-state policy change }\end{array}$ & $\begin{array}{c}\text { Appleton, Eau Claire, } \\
\text { Green Bay, Kenosha, } \\
\text { Madison, Manitowoc, } \\
\text { Marinette, Milwaukee, } \\
\text { Superior }\end{array}$ & $\begin{array}{c}\text { Appleton, Eau Claire, } \\
\text { Green Bay, Kenosha, } \\
\text { Madison, Manitowoc, } \\
\text { Marinette, Milwaukee, } \\
\text { Superior }\end{array}$ & $\begin{array}{c}\text { Appleton, Ashland, Eau } \\
\text { Claire, Fond du Lac, } \\
\text { Green Bay, Janesville, } \\
\text { Kenosha, La Crosse, } \\
\text { Madison, Manitowoc, } \\
\text { Marinette, Milwaukee, } \\
\text { Racine, Sheboygan, } \\
\text { Superior, Wausau }\end{array}$ & $\begin{array}{l}\text { Appleton, A shland, Eau } \\
\text { Claire, Fond du Lac, } \\
\text { Green Bay, Janesville, } \\
\text { Kenosha, La Crosse, } \\
\text { Madison, Manitowoc, } \\
\text { Marinette, Milwaukee, } \\
\text { Racine, Sheboygan, } \\
\text { Superior, Wausau }\end{array}$ & $\begin{array}{c}\text { Appleton, Eau Claire, } \\
\text { Green Bay, Kenosha, } \\
\text { Madison, Manitowoc, } \\
\text { Marinette, Milwaukee, } \\
\text { Superior }\end{array}$ \\
\hline
\end{tabular}

Notes: Data on state-level anti-TB interventions come from A TubeculosisDiretary, published in 1911, 1916, and 1919 by the National Association for the Study and Prevention of Tuberculosis. 
Appendix Table 3. Municipal and State Anti-TB Indices

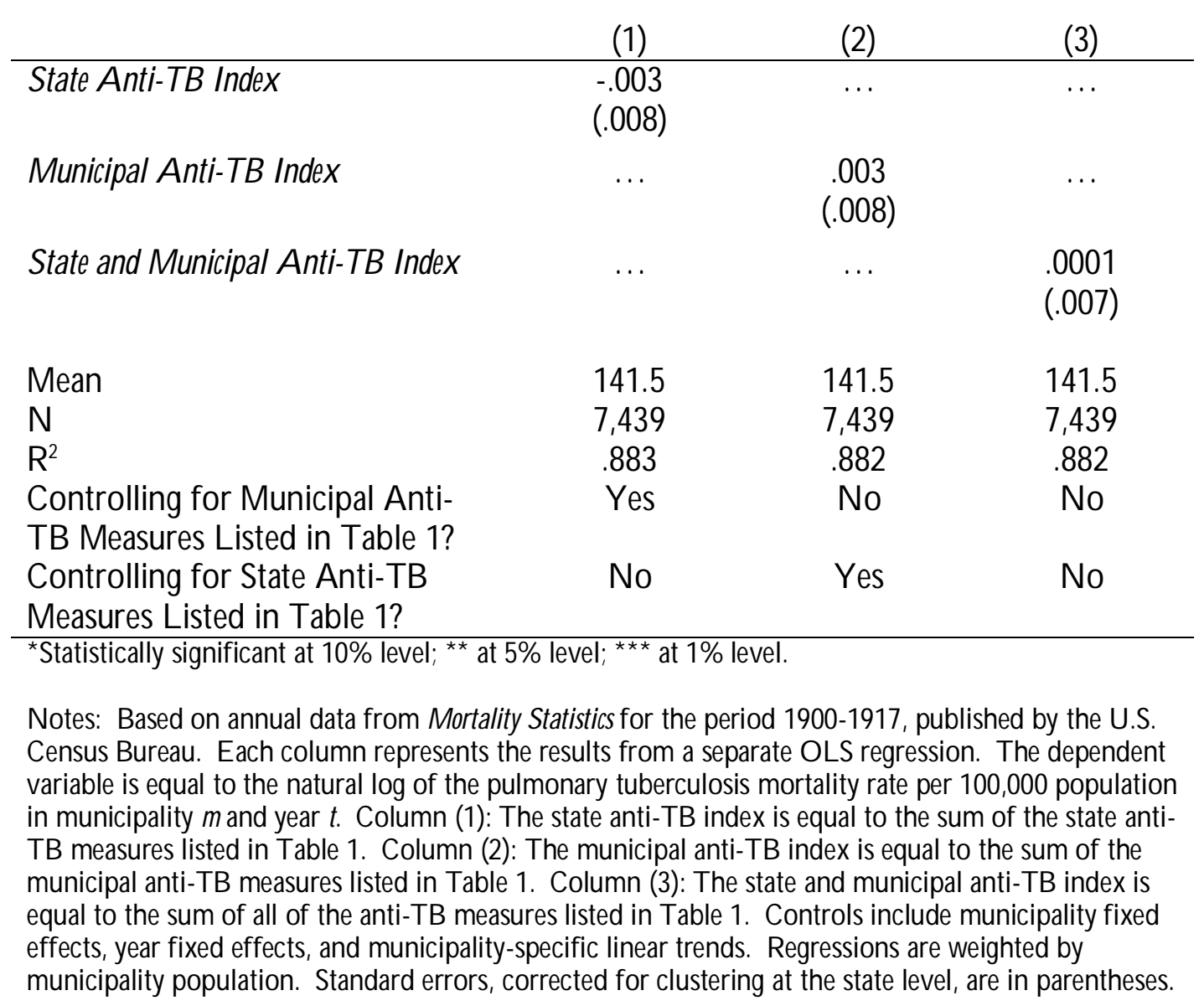


Appendix Table 4. Pulmonary TB Mortality and Leads and Lags of State-Run Sanatoriums

\begin{tabular}{|c|c|c|c|c|}
\hline & (1) & (2) & (3) & (4) \\
\hline 3 Yerrs Prior toStateRun Sanatorium & $\ldots$ & $\ldots$ & $\ldots$ & $\begin{array}{c}.005 \\
.017)\end{array}$ \\
\hline 2 Yers Prior to StateRun Sanatorium & $\ldots$ & $\ldots$ & $\begin{array}{c}.021 \\
(.030)\end{array}$ & $\begin{array}{l}.023 \\
. .033)\end{array}$ \\
\hline 1 Year Prior to StateRun Sanatorium & $\ldots$ & $\begin{array}{l}-.014 \\
(.017)\end{array}$ & $\begin{array}{l}-.004 \\
(.024)\end{array}$ & $\begin{array}{r}-.001 \\
(.029)\end{array}$ \\
\hline Yæar of StateRun Sanatorium & $\begin{array}{c}-.037 * * * \\
(.013)\end{array}$ & $\begin{array}{c}-.043^{* *} \\
(.018)\end{array}$ & $\begin{array}{l}-.033 \\
(.021)\end{array}$ & $\begin{array}{r}-.029 \\
(.027)\end{array}$ \\
\hline 1 Yær After StateRun Sanatarium & $\begin{array}{c}-.049 * * \\
(.020)\end{array}$ & $\begin{array}{c}-.056^{* *} \\
(.025)\end{array}$ & $\begin{array}{l}-.044 \\
(.026)\end{array}$ & $\begin{array}{r}-.040 \\
(.033)\end{array}$ \\
\hline 2 Yerrs After StateRun Sanataium & $\begin{array}{r}-.025 \\
(.023)\end{array}$ & $\begin{array}{c}-.033 \\
(.026)\end{array}$ & $\begin{array}{l}-.019 \\
(.026)\end{array}$ & $\begin{array}{r}-.015 \\
(.033)\end{array}$ \\
\hline 3+ YøarsAfter StateRun Sanatarium & $\begin{array}{l}-.041 \\
(.025)\end{array}$ & $\begin{array}{l}-.050^{*} \\
(.029)\end{array}$ & $\begin{array}{l}-.035 \\
(.029)\end{array}$ & $\begin{array}{l}-.031 \\
(.035)\end{array}$ \\
\hline $\begin{array}{l}\text { Mean } \\
\mathrm{N} \\
\mathrm{R}^{2}\end{array}$ & $\begin{array}{c}141.5 \\
7,439 \\
.883\end{array}$ & $\begin{array}{c}141.5 \\
7,439 \\
.883\end{array}$ & $\begin{array}{c}141.5 \\
7,439 \\
.883\end{array}$ & $\begin{array}{r}141.5 \\
7,439 \\
.883 \\
\end{array}$ \\
\hline
\end{tabular}

*Statistically significant at $10 \%$ level; $* *$ at $5 \%$ level; $* * *$ at $1 \%$ level.

Notes: Based on annual data from Matality Statisicsfor the period 1900-1917, published by the U.S. Census Bureau. Each column represents the results from a separate O LS regression. The dependent variable is equal to the natural log of the pulmonary tuberculosis mortality rate per 100,000 population in municipality mand year $\mathrm{t}$ Controls include the covariates listed in Table 1, municipality fixed effects, year fixed effects, and municipality-specific linear trends. Regressions are weighted by municipality population. Standard errors, corrected for clustering at the state level, are in parentheses. 